\title{
Russian Soft Power Cultivation in the United States of America: A Media Content Analysis of "Russia Beyond The Headlines"
}

\author{
David Evans \\ West Virginia University
}

Follow this and additional works at: https://researchrepository.wvu.edu/etd

Part of the Diplomatic History Commons, Mass Communication Commons, Other History Commons, Political History Commons, and the Social Influence and Political Communication Commons

\section{Recommended Citation}

Evans, David, "Russian Soft Power Cultivation in the United States of America: A Media Content Analysis of "Russia Beyond The Headlines"'" (2015). Graduate Theses, Dissertations, and Problem Reports. 8157. https://researchrepository.wvu.edu/etd/8157

This Thesis is protected by copyright and/or related rights. It has been brought to you by the The Research Repository @ WVU with permission from the rights-holder(s). You are free to use this Thesis in any way that is permitted by the copyright and related rights legislation that applies to your use. For other uses you must obtain permission from the rights-holder(s) directly, unless additional rights are indicated by a Creative Commons license in the record and/ or on the work itself. This Thesis has been accepted for inclusion in WVU Graduate Theses, Dissertations, and Problem Reports collection by an authorized administrator of The Research Repository @ WVU. For more information, please contact researchrepository@mail.wvu.edu. 


\title{
Russian Soft Power Cultivation in the United States of America: A Media Content Analysis of Russia Beyond The Headlines
}

\author{
David Evans
}

\begin{abstract}
Thesis submitted to the Eberly College of Arts and Sciences at West Virginia University in partial fulfillment of the requirements for the degree of

Master of Arts in History
\end{abstract}

\author{
Robert Blobaum, Ph.D., Chair \\ James Siekmeier, Ph.D. \\ Erik Herron, Ph.D.
}

Department of History

Morgantown, West Virginia

2015

Keywords: Soft Power, Russian Federation, US Media Outlets, Public Diplomacy, International Relations, US-Russia Relations, Media Analysis

David Evans 


\section{Abstract}

Russian Soft Power Cultivation in the United States of America: A Media Content Analysis of

Russia Beyond The Headlines

David Evans

The relationship between Russia and the United States of America has been a dominant feature of the international relations landscape for much of the last century. Following the collapse of the Soviet Union, this relationship has been significantly altered. Over the last decade, a resurgent Russia has begun to exert its influence on the global stage once again. This effort has been characterized by a mixture of traditional "hard power" and a relatively new form of "soft power." The government of the Russian Federation has developed a broad strategy for engaging the rest of the world with the intention of improving the image of Russia. One component of this effort began in 2007 when the Russian-government-owned Rossiyskaya Gazeta newspaper began to publish a supplemental news section in the Washington Post and the Daily Telegraph. This supplemental news section is now known as Russia Beyond the Headlines, and it is published in 26 countries and 16 languages. The purpose of this publication is to engage an elite section of foreign audiences around the world, and hopefully influence their mindset as it relates to Russia. This thesis provides a historical background of the Soviet Union and Russian Federation's efforts at cultivating soft power in general, as well as an indepth study of the content of Russia Beyond the Headlines during 2014 in the three domestic US newspapers (the Washington Post, the New York Times and the Wall Street Journal). This study ultimately concludes that the content of Russia Beyond the Headlines within the US market is adequately able to achieve its goals through a variety of strategies, and that further research is needed to understand the larger impact of the Russian Federation's exercise of soft power in both the United States of America and around the world. 



\section{Table of Contents}

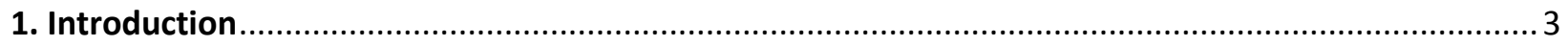

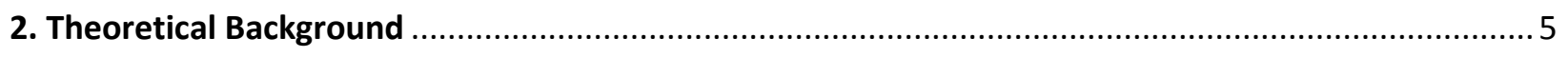

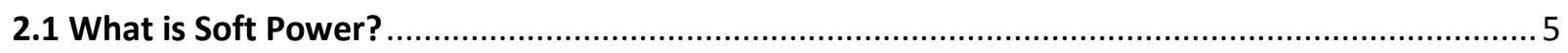

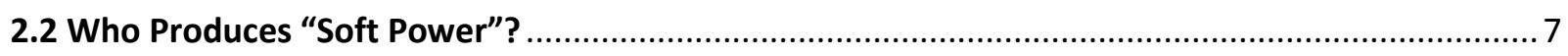

2.3 How is Soft Power Implemented? A Brief History of Public Diplomacy in the West.................... 9

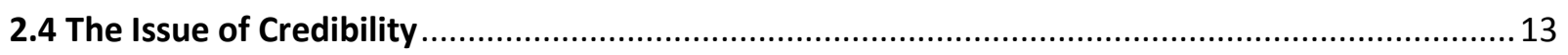

2.5 Russian Soft Power/Public Diplomacy vs. Western Soft Power/Public Diplomacy.....................18

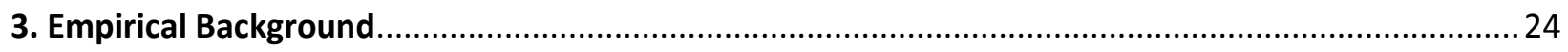

3.1 The History of the Development of Russian/Soviet Soft Power and Public Diplomacy ...............24

The Soviet Union's Soft Power/Public Diplomacy ....................................................................... 24

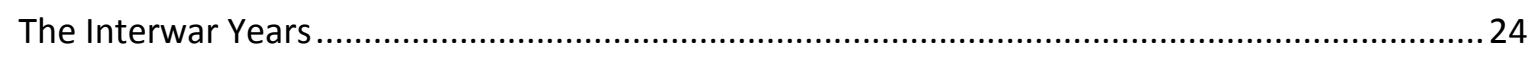

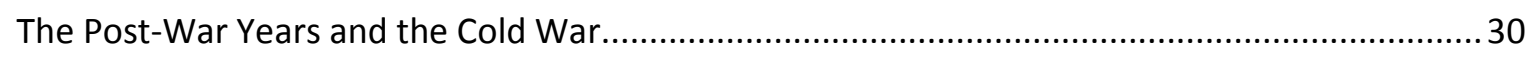

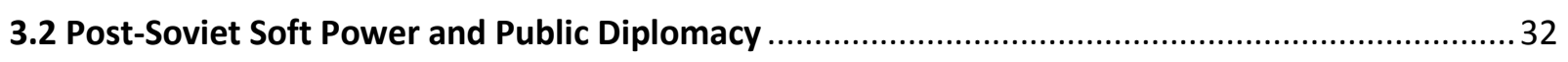

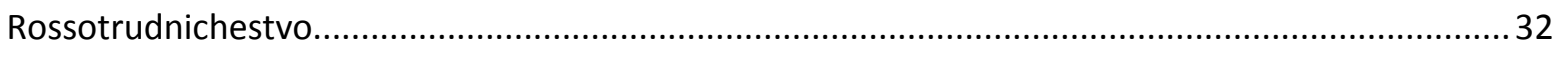

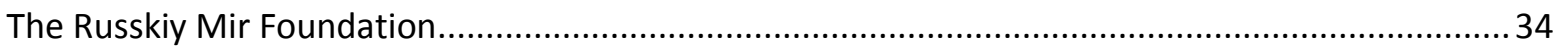

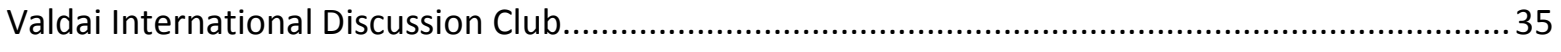

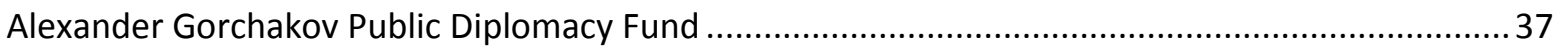

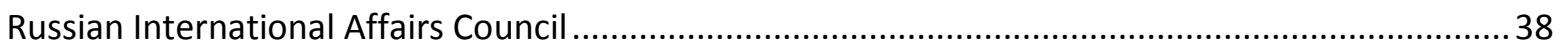

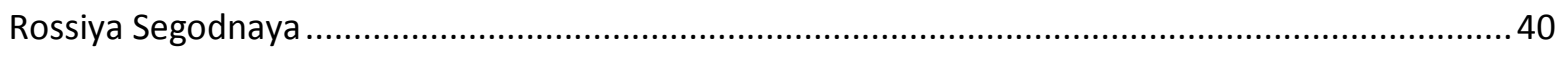

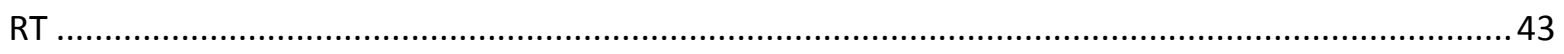

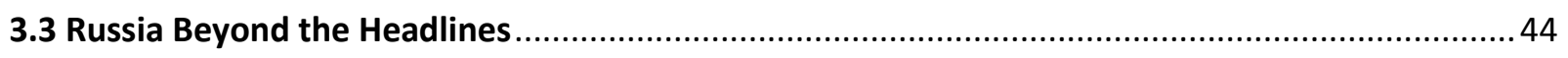

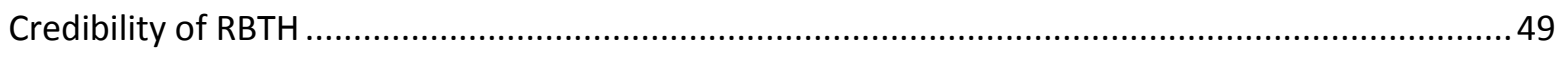

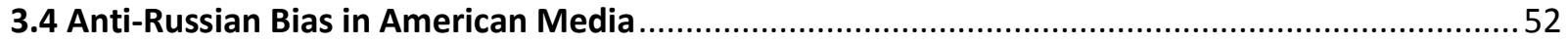

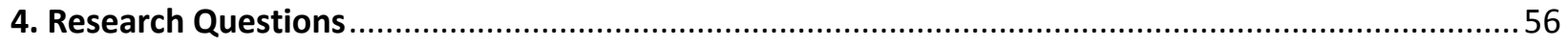

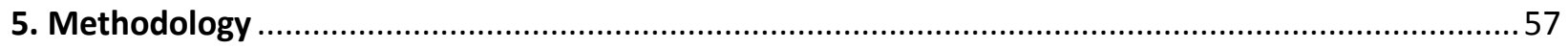

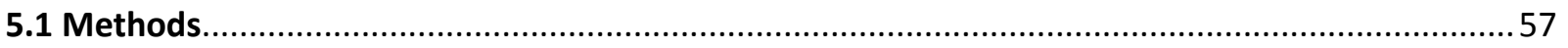

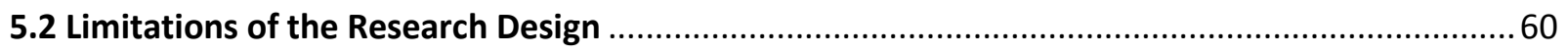

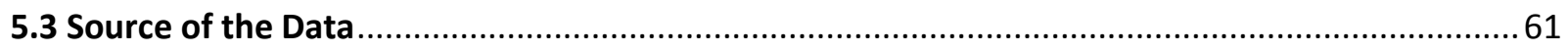

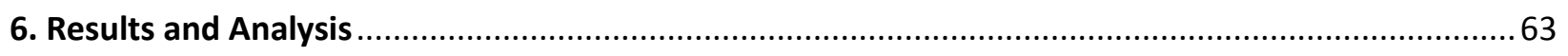

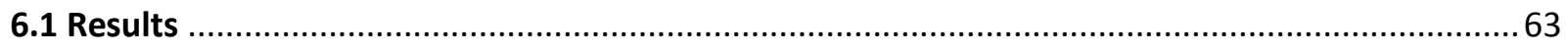

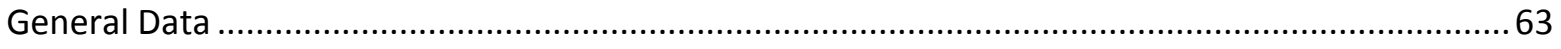

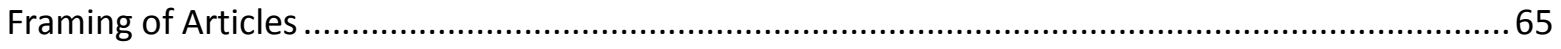




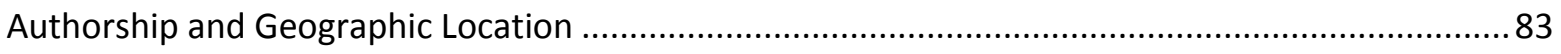

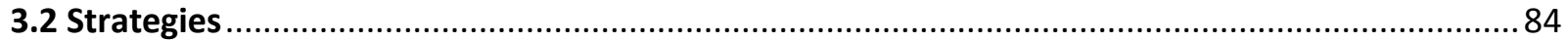

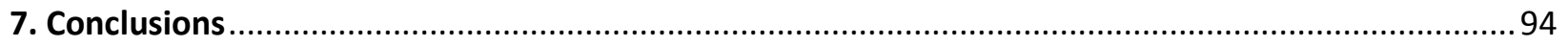

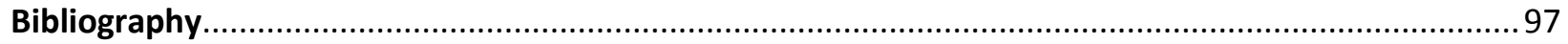

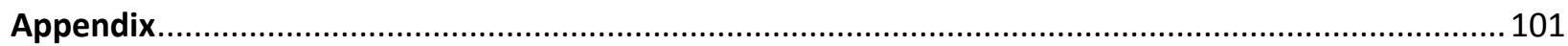

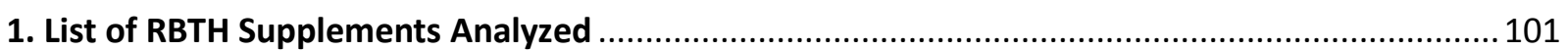




\section{Introduction}

After the end of the Cold War and the collapse of the Soviet Union, many experts around the world decided that the Soviet Union's successor state, the Russian Federation, no longer had any viable means of competing with the Western world. In the beginning this was certainly true. Russia's economy was in terrible shape, and the transition from a centrally planned economy to a free market economy was proving to be difficult for most if not all countries participating in this process, and this was certainly the case for the world's largest country by size. However, the beginning of the $21^{\text {st }}$ century has seen the reemergence of Russian power due largely to the rising price of oil and natural gas, which Russia has in abundance, along with the stabilization of the political situation under the rule of Vladimir V. Putin.

As a result of this economic and political resurgence, Russia has begun again to demand that its interests on the world stage should be respected. In the last year and half, we have seen this geopolitical competition turn hot in Ukraine. Both sides have openly been speaking of the start of a new Cold War. Opinion polls in Russia and the United States have shown that both countries' general publics have followed their leaders on the march toward a renewed conflict, whether it be cold or hot remains to be seen.

However, these old tendencies come in a different era. The world is no longer ideologically divided between totalitarian communism and free-market democracy. The world has globalized. We are more inter-connected today than we ever have been. It is now possible, thanks to the internet and inventions like Skype, to communicate to friends and family around 
the world for little to no cost. Social networking has provided voices for those that were voiceless. In addition, the rise of new rivals such as the European Union, China, and the rest of the BRICS countries has challenged the traditional notion of a US-Soviet bipolarity or US unipolarity in international relations.

The larger changes in the world have also led to changes in the rivalry between the US and Russia. Perhaps the most notable example of this is that the Russian Federation has recently been investing in boosting its soft power/public diplomacy capabilities. This noticeably different strategy in the struggle for influence in the world is one that is not new to the US nor much of the Western world. In fact, the Soviet Union made a few attempts at its cultivation, but ultimately these failed due to a variety of factors. Today, Russia has decided to give it another go, and for the last decade, the Russian Federation has funded a variety of soft power/public diplomacy initiatives. Many of these initiatives are rather new and have thus gone virtually unstudied, at least in a systematic methodological manner.

One such soft power/public diplomacy initiative is called Russia Beyond the Headlines, and this will be the focal point of the following thesis. This thesis will explore the nature and theories behind soft power and public diplomacy, as well as provide a brief historical background of both the general history of soft power/public diplomacy around the world, and more specifically, its history in Russia and the former Soviet Union. The heart of this thesis will be a systematic analysis of the structure, goals, strategies and overall effectiveness of Russia Beyond the Headlines as a soft power/public diplomacy cultivation method during the tumultuous year of 2014 . 


\section{Theoretical Background}

\subsection{What is Soft Power?}

The concept of "hard power" vs. "soft power" has become increasingly prevalent within international relations, both in the academic world and in the political realm. The initial term of "soft power" as a contrast to a traditional "hard power" was first established by John Nye, Jr. In a recent TED Talks speech, Nye describes the differences between traditional hard powers of "carrots" and "sticks" and his idea of "soft power" by stating "[p]ower is simply the ability to affect others to get the outcomes you want, and you can do it in three ways. You can do it with threats of coercion, "sticks," you can do it with payments, "carrots," or you can do it by getting others to want what you want. And that ability to get others to want what you want, to get the outcomes you want without coercion or payment, is what I call soft power." ${ }^{1}$ In this sense, "soft power" is essentially a more nuanced strategy of achieving a person or a state's goals, without resulting to outright force by bullying or coercion through bribery. Furthermore, Nye defines "soft power" as "the ability to get what you want through attraction rather than coercion or payments. It arises from the attractiveness of a country's culture, political ideals, and policies. When our policies are seen as legitimate in the eyes of others, our soft power is

\footnotetext{
${ }^{1}$ Films for the Humanities \& Sciences (Firm), Films Media Group, and TED Conferences LLC, TEDTalks Joseph Nye Global Power Shifts, electronic resource (video) (Films Media Group, 2012).
} 
enhanced." 2 This "attractiveness" is key to understanding the stated goals of the Russian Federation and the usefulness of Russia Beyond the Headlines (RBTH).

Nye also argues that "soft power", when properly employed, enriches a state's "hard power." Similarly, "soft power" typically manifests itself in direct relation or conflict to "hard power." However, Nye argues that "soft power" is a means of attraction, and that "[i]f you can add the soft power of attraction to your toolkit, you can economize on carrots and sticks." ${ }^{3}$ In other words, by implementing a cohesive strategy of effective "soft power", a state is able to make its use of coercion ("carrots") or possible force ("sticks") all the more meaningful and potent weapons in international diplomacy. If a country is able to bring its "hard" and "soft" power into line with each other, then that country is able to produce a type of symbiosis that Nye coins as "smart power."

The dream of "smart power" for a nation is not an easy one to achieve according to Nye. In a recent article for Foreign Policy entitled "What Russia and China Don't Get About Soft Power," Nye states that "[t]he soft power of a country rests primarily on three resources: its culture (in places where it is attractive to others), its political values (when it lives up to them at home and abroad), and its foreign policies (when they are seen as legitimate and having moral authority). But combining these resources is not always easy." ${ }^{5}$ He goes on to argue that both Russia and China share a fatal flaw in their intended "soft power" strategies, and that is because "soft power" should be produced primarily by non-governmental actors, which he

\footnotetext{
2 Joseph S Nye, Soft Power: The Means to Success in World Politics (New York: Public Affairs, 2004), x.

${ }^{3}$ Joseph S Nye, "What China and Russia Don't Get About Soft Power," Foreign Policy, accessed February 16, 2015, http://foreignpolicy.com/2013/04/29/what-china-and-russia-dont-get-about-soft-power/.

${ }^{4}$ Films for the Humanities \& Sciences (Firm), Films Media Group, and TED Conferences LLC, TEDTalks Joseph Nye Global Power Shifts; Nye, "What China and Russia Don't Get About Soft Power."

${ }^{5}$ Nye, "What China and Russia Don't Get About Soft Power."
} 
argues is largely the case in America. He states that "government propaganda is rarely credible. The best propaganda is not propaganda." ${ }^{6}$ Despite this critique, both countries continue to employ government-driven "soft power" initiatives.

\subsection{Who Produces "Soft Power"?}

Although Nye's creation of the word "soft power" is only a little more than a quarter of a century old, the underpinning ideals have been in practice for a considerable amount of time. Perhaps the best example of a state employing "soft power" strategies has been that of the United States of America. The Declaration of Independence is an excellent example of just such a use of "soft power." By making what was essentially a simple tax dispute into a lyrically-based diatribe professing the leading Enlightenment ideals of the time, American colonists were able to curry favor among the great powers in Europe, and eventually were able to rouse French support, which proved crucial in the eventual colonial victory. I am not arguing that one led directly to the other, but there is no denying that Jefferson's rhetoric played a role in currying favor with France and Europe. The ideals expressed in the declaration have since become a cornerstone of the American "identity", and their use and the subsequent additions to them have served over the years to be powerful propaganda and a fundamental aspect of America's "soft power." In this sense, Nye's assertion that "government propaganda is rarely credible" should be taken with a grain of salt. Government propaganda can be credible if it has been established long enough in a general narrative of a state's perception by the rest of the world.

\footnotetext{
${ }^{6}$ Ibid.
} 
Nye argues that "[m]uch of America's soft power is produced by civil society everything from universities and foundations to Hollywood and pop culture - not from the government."7 This assertion is one that should probably be challenged by more scholars, but this is not the appropriate place to do so. However, it is important to point out that the United States' narrative is strongly reaffirmed by many universities (many of which are publicly funded by the government) and a variety of foundations and think tanks (largely staffed by former academics from the universities mentioned above or former government employees). Furthermore, Hollywood and pop culture do a tremendous job of instilling fierce patriotism and scenes of unbelievable grandeur relating to a mythologized America, and its history, politics, and cultural superiority. This sort of all-encompassing patriotism and often blind retelling of propaganda should be studied more carefully before statements such as Nye's are taken at face value. Again this is not the place to discuss this further, but the point is that who creates "soft power" is very rarely an entity entirely separated from the government that it is supporting. If "smart power" comes from the symbiotic relationship between "hard" and "soft" power, then it must stand to reason that their relationship is closer than simply a government and an "independent" civil society which explicitly supports the decisions and grandeur of that government.

Again, this is not the place for a deeper discussion of American "soft power," but I bring it up simply to point out that the relationship between government and "soft power" is closer than sometimes perceived, and that is certainly the case for Russia, although I would argue that they are not alone in this strategy or system of producing "soft power" throughout the world.

\footnotetext{
${ }^{7}$ Ibid.
} 
In other words, the production of "soft power" in conjunction with government is the norm, instead of the exception. However, I argue that the perception of the separation can and should be seen as a part of a "soft power" narrative. In fact, the lack of a perception of separation between government and an "independent" civil society have been the impetus for Russia's program of "soft power" promotion. However, that will be dealt with a little later in this chapter.

Indeed, other scholars have argued against Nye's assertion that soft power is separate from the government. Ying Fan argues that a better interpretation of "soft power" is that of "cultural power" that comes directly from core values and domestic institutions, which are not separate sources of "cultural power," but in fact they are essential parts of a society's culture. ${ }^{8}$ Fan goes on to argue that these core values and domestic institutions are fundamentally shaped by the policies and actions of the government. ${ }^{9}$ In essence, Fan argues that many of these "independent" sources of "soft power" create "potential soft power," which the government then selects those pieces of "potential soft power" that fit in with its policies, and use them. As a result, the "potential soft power" produced by these "independent" agents are in fact, cooperative with (if not reliant on) the support and continued use of their products, which means that the processes of both should not be considered separate.

\footnotetext{
8 Ying Fan, "Soft Power: Power of Attraction or Confusion?," Place Branding and Public Diplomacy 4, no. 2 (May 2008): 4, doi:10.1057/pb.2008.4.

${ }^{9}$ Ibid., 4-5.
} 
Nye defines "soft power" as a tool that can be used in order to attract other countries to want what you want. In order to implement this tool, governments often turn to what is called "public diplomacy." The US State Department's website defines "[t]he mission of American public diplomacy is to support the achievement of U.S. foreign policy goals and objectives, advance national interests, and enhance national security by informing and influencing foreign publics and by expanding and strengthening the relationship between the people and Government of the United States and citizens of the rest of the world."10 It goes on to explain that this is achieved by doing a variety of activities, which includes communications with international audiences, cultural programming, academic grants, educational exchanges, international visitor programs, and U.S. Government efforts to confront ideological support for terrorism."11 In the same vain, public diplomacy is defined by Nye, in relationship to soft power, as "an instrument that governments use to mobilize [soft power] resources to communicate and attract the publics of other countries rather than merely their governments." 12 In other words, public diplomacy is the mechanism by which governments pursue their soft power goals.

Public diplomacy is not just a policy tool of the United States, and it is not new. For centuries, prestige in Europe was determined largely by military and territorially strength. In the late $18^{\text {th }}$ and early $19^{\text {th }}$ centuries, the rising tide of nationalism throughout Europe began to

\footnotetext{
${ }^{10}$ Bureau of Public Affairs Department Of State. The Office of Website Management, "Under Secretary for Public Diplomacy and Public Affairs," January 20, 2009, http://www.state.gov/r/.

${ }^{11} \mathrm{lbid}$.

12 Joseph S. Nye Jr., "Public Diplomacy and Soft Power," Annals of the American Academy of Political and Social Science 616 (March 1, 2008): 95.
} 
establish a clear set of parameters for who a people were and who they were not. ${ }^{13}$ As the ideas manifested themselves at home and solidified into a cohesive narrative, nations then began to want to promote that narrative beyond their borders. During the later portion of the $19^{\text {th }}$ century, with the advent of faster communication, the ability for these nation-states to exert their influence in other countries became easier. In 1883, after the French loss in the Franco-Prussian War had left the country's prestige damaged, the French government established the Alliance Francaise, which was tasked with promoting French language and literature abroad, and soon this led to the "projection of French culture abroad [which] became a significant component of French diplomacy." ${ }^{14}$ This tactic was soon established around the rest of the continent and in the United States. In fact, during the early years of World War I, the British and the Germans actively used their soft power resources to attempt to persuade the Americans to join the war on their side. ${ }^{15}$

Soft power continued to be used and fostered for years after the First World War. During the interwar period, the invention of the radio allowed for easier dispersal of what was little more than governmental propaganda to be spread to all reaches of the Earth by most European powers along with the United States. ${ }^{16}$ After the outbreak of the war, the US expanded its operations even further and what became known as the "Voice of America "modeled [itself] after the BBC, [and] by 1943 it had twenty-three transmitters delivering news

\footnotetext{
${ }^{13}$ Benedict R. O'G Anderson, Imagined Communities: Reflections on the Origin and Spread of Nationalism (London; New York: Verso, 1991).

${ }^{14}$ Richard H Pells, Not like Us: How Europeans Have Loved, Hated, and Transformed American Culture since World War II (New York, NY: Basic Books, 1997), 31.

${ }^{15}$ Nye, "Public Diplomacy and Soft Power," 96.

16 lbid., 96-97.
} 
in twenty-seven languages." 17 In addition to increasing its presence abroad, the United States government also worked to foster support through the use of Hollywood films. The Office of Wartime Information "worked to shape Hollywood into an effective propaganda tool, suggesting additions and deletions to many films and denying licenses to others. And Hollywood executives were happy to cooperate out of a mixture of patriotism and selfinterest." 18 To what extent this cooperation has ceased to exist is unknown, but the prevalence of patriotic ideals and sometimes seemingly blatant propaganda in many American films indicates that some relationship, whether tacit or direct, still exists today.

As the Cold War began after World War II, the United States increased its soft power presence dramatically across Europe and the rest of the World. "Special radios were added such as Radio Liberty and Radio Free Europe, which used exiles to broadcast to the Eastern bloc." 19 Hollywood movies and news media, along with cultural exchanges and other aspects of public diplomacy, were used effectively and generously across Europe and around the world in order to foster goodwill towards America. After the collapse of the Soviet Union and communism in Europe, American efforts did not stop in any of these places, or the rest of the world for that matter, but their budgets were cut significantly, and would not reemerge until the September $11^{\text {th }}$ terrorist attacks and the subsequent "war on terror."20

With the advent of the so-called information age, sources of information have become much more widely available, and thus, the government's ability (or anyone's for that matter) to

\footnotetext{
17 Ibid., 97.

18 Ibid.

19 Ibid.

20 Ibid., 97-98.
} 
control information output has become undermined. The wide variety of sources of information has grown exponentially since the internet boom has taken place. Traditional media (newspapers, newsreels, etc.) have suffered as a result of this explosion of information. However, the credibility that the traditional media and some governments have established remains a vital aspect of the effective use of soft power. As Nye explains, "credibility is the crucial resource and an important source of soft power. Reputation becomes even more important than in the past, and political struggles occur over the creation and destruction of credibility. Governments compete for credibility not only with other governments but with a broad range of alternatives including news media, corporations, nongovernmental organizations (NGOs), intergovernmental organizations, and networks of scientific communities. Politics has become a contest of competitive credibility... governments compete with each other and with other organizations to enhance their own credibility and weaken that of their opponents." ${ }^{21}$ This competition among governments and other activities is at the core of the modern public diplomacy "battles" that rage around the world. The main purpose of this thesis is to look at one of these "battles" in particular, and it takes place on a new battlefield that has only recently been created.

\subsection{The Issue of Credibility}

As discussed above, credibility is at the heart of any effective use or development of soft power. The variety of different avenues with which Russia has engaged with the rest of the

\footnotetext{
${ }^{21}$ Ibid., 100.
} 
world and the United States of America in particular have all faced a variety of credibility and propaganda accusations (discussed further in the Empirical Background chapter). The issue of credibility that is important to this thesis is the credibility of the RBTH inserts that are featured in The Washington Post, The Wall Street Journal, and The New York Times. Why does RBTH maintain a sense of credibility? What makes a publication or article credible?

In general, the accumulation of credibility, and the maintenance of that credibility, can occur in primarily three ways. First, is the established credibility that a state has built up over time, and which is specific to each state, each culture, and truly to each individual in much the same way that identity and narratives are understood to occur. Ben D. Moor describes this by saying that "[i]ndeed, the ubiquity of credibility talk, even across cultures, indicates that the process itself of crediting proffered arguments has deep psychological roots, related to the stability of identities and the emergent social order."22 The myriad of different influences that affect our perception of the world will influence our own perceived idea of the credibility of the source material. General trends within a culture or state can still be gleaned from various methods, such as opinion polls, surveys, etc. despite the individual nature that is inherent within the question of perception. In the same vain, the perception of a country and its implementation of soft power cultivation techniques (i.e. RBTH, RT, RIANOVOSTI (now Sputnik), Rossotrudnichestvo, etc.) comes from the media, NGO analysts, and government officials of the country where these activities are undertaken. This is often understudied because of the sheer volume of information, but in general, it can be assumed that with respect to Russia, the United States media, NGO analysts, and government officials, along with a wide variety of other

\footnotetext{
22 Ben D. Mor, "Credibility Talk in Public Diplomacy," Review of International Studies 38, no. 2 (April 2012): 394, doi:http://dx.doi.org.www.libproxy.wvu.edu/10.1017/S0260210511000489.
} 
influence makers (i.e. comedians, TV shows, movies, etc.) portray Russia in a particularly negative light, and are often suspicious of the intentions of Russia and Russians in general (discussed further in the Empirical Background chapter).

The second means by which credibility is achieved, is by linking itself to an already credible institution. By doing this, a piece of soft power cultivation can prove fruitful by the mere association with the credible source. This is the case with RBTH, and part of the reason for its success (discussed further in the Empirical Background chapter). In short, RBTH has selected three of the most credible and respected newspapers in America to attach itself to. The inserts are meant to look as similar to the actual newspapers as possible. They appear to be just another section of the paper that just happens to be focused on Russia. Although there is a brief description that states that RBTH is not affiliated with the newspaper in question, the insert otherwise shows little signs of being separate from the rest of the paper. By attaching itself to the newspaper, RBTH is able to gain legitimacy and credibility (not to mention circulation) without any outside influence in the editorial process. This technique is fairly effective, as long as it is done in conjunction with the third method.

The third method of obtaining and maintaining credibility is through the consistency with which an entity conducts itself and presents its information. Moor explains that "[c]onsistency is a strong determinant of credibility (hence the prominence of discrepancy charges in discrediting strategies), and if a state's advocacy is perceived as incompatible with its foreign policy or military action, its reputation [soft power] and public diplomacy suffer."23 Similarly, this goes to the heart of Nye's argument for why governments tend to be ineffective ${ }^{23} \mathrm{lbid}$. 
as purveyors of soft power. Too often, their activities are seen as simple propaganda and they can even do damage to a nation's credibility. As Nye states, "[i]nformation that appears to be propaganda may not only be scorned, but it may also turn out to be counterproductive if it undermines a country's reputation for credibility." 24

The final method of obtaining and maintaining credibility is to create at least the illusion that the instrument is not simply a tool of the government of the home country. Objectivity or at least the perception of some level of objectivity is crucial to the success of the soft power cultivation tool. Objectivity is defined by Merriam Webster as "expressing or dealing with facts or conditions as perceived without distortion by personal feelings, prejudices, or interpretations." 25 The perception of objectivity is clearly more difficult to obtain for a government than it is for an individual or independent organization. Nye explains this relationship by stating that "postmodern publics are generally skeptical of authority, and governments are often mistrusted. Thus, it often behooves governments to keep in the background and to work with private actors."26

As I will discuss in greater detail later in this chapter, Russia does not operate in a manner similar to that of the West in terms of government's role in soft power cultivation and public diplomacy. As a result, Russian soft power cultivation attempts inherently face skepticism. In order to combat this natural stigma, the Russian government must attempt to establish its objectivity, and subsequently its credibility, in a different way. The most straight

\footnotetext{
${ }^{24}$ Nye, "Public Diplomacy and Soft Power," 100.

${ }^{25}$ Merriam Webster, "Definition of Objective," accessed February 19, 2015, http://www.merriamwebster.com/dictionary/objective.

${ }^{26}$ Nye, "Public Diplomacy and Soft Power," 105.
} 
forward way to accomplish this is through self-criticism. As Nye states "it is sometimes domestically difficult for the government to support presentation of views that are critical of its own policies. Yet such criticism is often the most effective way of establishing credibility." 27 At the very least, the acknowledgment of topics that might be banned or taboo in the home county but generally accepted as reasonable topics in the receiving country should be discussed in an open and frank manner that would be normal for the press of the receiving country to publish. The nature of soft power cultivation must be toward a conversation with the target audience on its level, which Nye explains by stating that "[b]y definition, soft power means getting others to want the same outcomes you want, and that requires an understanding of how they are hearing your messages and adapting them accordingly. It is crucial to understand the target audience."28

Soft power is fundamentally about seduction. A state is hoping that through soft power cultivation tools a person or group of people will find its image attractive, and thus they will be more willing to support the actions of the government, the businesses, and the wider aims of this foreign state. "Policies that appear as narrowly self-serving or arrogantly presented are likely to prohibit rather than produce soft power."29 Instead, the soft power cultivation tools must present a credible story that appears to be objective on at least some reasonable level, and that speaks directly to the target audience in a clear, concise, logical manner that is consistent with the normal dialogue of the medium being used in order to be effective. This thesis will analyze RBTH, and determine whether it is able to accomplish these criteria.

\footnotetext{
27 Ibid., 106.

28 Ibid., 103.

${ }^{29}$ Ibid., 102.
} 


\subsection{Russian Soft Power/Public Diplomacy vs. Western Soft Power/Public Diplomacy}

The perception in Russia of soft power and public diplomacy is slightly different from that of its Western counterparts, for a variety of reasons. Alexey Dolinsky identifies a few of these reasons in a recent paper about a roundtable discussion on public diplomacy sponsored in June 2012 by the Russian Council for International Affairs. The first issue that he identifies deals with the translation and definition in Russian. The term as literally translated mean “общественная дипломатия" in Russian, and for some time this translation was used. However, this term has a connotation and understanding in Russian that created "a dangerous confusion: even certain experts are convinced that public diplomacy is no more than a dialog at the level of non-government organizations." ${ }^{30}$ As discussed above, this leaves out a large chunk of the Western definition of public diplomacy. As a result, the more appropriate translation should be “публичная дипломатия", which carries roughly the same meaning and connotations as the English term "public diplomacy." 31 Furthermore, the issue of the translation and the definition of the English term "soft power" in Russian can also be an issue. As Dolinsky describes it, "[t]he term "soft power" was translated into Russian in different ways at different times - as «мягкая мощь» [мягкая means "soft" or "mild" and мощь means "power" or "might"], «гибкая сила» [гибкая can mean "soft" but also "flexible" or "supple", and сила means "force" "strength" or "power"] etc. Today the most widely used translation is «мягкая сила»; however, the term «власть» [власть means "power", "authority" or "rule"] -

\footnotetext{
${ }^{30}$ Alexey Dolinsky, "RIAC :: 'What Is Public Diplomacy, and Why Russia Needs It?,'” accessed February 17, 2015, http://russiancouncil.ru/en/inner/?id_4=913\&from=nov\#top.

${ }^{31} \mathrm{lbid}$.
} 
as an ability to make others do what one wants - seems to be closer to the original meaning than "сила»." 32 However, much of the early confusion over the dynamics of the literal name have been discarded as a result of President Putin's various speeches on the subject of soft power and public diplomacy.

In a speech to Foreign Service officers on July 9, 2012, Putin described his own and thus Russia's understanding of soft power. He stated "that 'soft power' is all about promoting one's interests and policies through persuasion and creating a positive perception of one's country, based not just on its material achievements but also its spiritual and intellectual heritage. Russia's image abroad is formed not by us and as a result it is often distorted and does not reflect the real situation in our country or Russia's contribution to global civilization, science and culture. Our country's policies often suffer from a one-sided portrayal these days... But our fault lies in our failure to adequately explain our position. This is where we have gone wrong." ${ }^{33}$ He goes on to point out that Russia must promote the use of the Russian language and cultivate assets among Russian "compatriots" and ex-patriots living abroad, who he claims are more willing to help their mother country then previously understood. ${ }^{34}$ It is here, and in a variety of similar speeches and articles like it, that Putin shows his most dramatic and meaningful divergence from the Western view of what soft power is and how it should be used. Putin's view of soft power is less about attraction and more about coercion and confrontation. He certainly understands that the promotion of Russian culture, language, etc. can help to provide Russia with tangible advancements in politics and economics abroad. However, he fails to take

\footnotetext{
32 Ibid.

${ }^{33}$ Vladimir Putin, "Meeting with Russian Ambassadors and Permanent Representatives in International Organisations" (President of Russia, July 9, 2012), http://eng.kremlin.ru/transcripts/4145.

34 Ibid.
} 
into account the larger nature that Nye has identified as being the three resources that a country relies on to establish and increase its soft power.

Once again, the three resources that Nye argues are foundationally vital to a state's soft power are: "[1] its culture (in places where it is attractive to others), [2] its political values (when it lives up to them at home and abroad), and [3] its foreign policies (when they are seen as legitimate and having moral authority)." ${ }^{35}$ Putin clearly understands the first of these criteria. He also understands that Russia must defend the legitimacy of its foreign policies and actively engage in promoting the morality and reasoning behind them. However, Putin makes no mention of the importance of emphasizing Russia's political values except through the justification that the other side is doing the same thing (i.e. two wrongs make a right). In fairness, this type of rationale can stand up to reason, but it rarely helps to garner goodwill for either side. The reasoning behind this omission may be due to Russian politics and Western politics having substantially different ideas of how the other works and who is correct. Nevertheless, Putin still sees many of the goals of soft power in at least a fairly similar light to that of the West, and this thesis will analyze how one tool of Russian soft power adheres to the presumptions of soft power in both the theorized Western and the theorized Russian concepts.

Finally, the Russian notion of soft power, unlike its Western counterparts, is essentially propelled and generated primarily by the state itself. As stated above, Nye argues that soft power should be primarily cultivated by non-governmental organizations (i.e. the domestic film industry; the domestic, independent news media; independent NGOs; etc.). ${ }^{36}$ However, the

\footnotetext{
${ }^{35}$ Nye, "What China and Russia Don't Get About Soft Power."

36 Ibid.
} 
nature of Russia is such that the existence of these entities do not exist, are underfunded or deemed "unreliable" for proper soft power cultivation. In fact, many of these groups that are separate of the government umbrella in Russia are active in undermining the credibility of the Russian government, and thus its ability to cultivate and grow the soft power of the state. As a result, the government has undertaken the majority of the burden for this creation of soft power around the world. However, Putin's regime is mindful of that which it does not necessarily possess. In its attempt to cultivate soft power, the Russian government has funded a variety of media initiatives (including RBTH), along with creating and/or funding a variety of NGOs. These institutions claim to operate in a manner that is similar to their Western "independent" counterparts. Whether they accomplish this claim or not is at the heart of this thesis.

The nature of Russian soft power and public diplomacy can be seen as a hybridization of their traditional Western understandings. The end result is a system of government-funded media outlets, NGOs, exchange programs, cultural programs, language schools, etc. that are meant to function in much the same way as their Western "independent" counterparts. The idea of objectivity in any entity that is attempting to utilize public diplomacy is questionable at best. The term "public diplomacy" was itself coined by Dean Edmund A. Gullion of the Fletcher School of Law and Diplomacy in the mid-1960s in order to describe this new concept. Subsequently, he went on to describe how the naming of this practice came into being and its relationship with propaganda: "Even beyond the organ of the Government set up to handle information about the United States and to explain our policies, what is important today is the interaction of groups, peoples, and cultures beyond national borders, influencing the way 
groups and peoples in other countries think about foreign affairs, react to our policies, and affect the policies of their respective governments. To connote this activity, we at the Fletcher School tried to find a name. I would have liked to call it 'propaganda.' It seemed like the nearest thing in the pure interpretation of the word to what we were doing. But 'propaganda' has always a pejorative connotation in this country. To describe the whole range of communications, information, and propaganda, we hit upon 'public diplomacy'." 37 Merriam Webster defines "propaganda" as "ideas or statements that are often false or exaggerated and that are spread in order to help a cause, a political leader, a government, etc." 38 To disparage Russia's hybrid version of public diplomacy as mere propaganda is essentially the pot calling the kettle black.

What then becomes important is the idea of credibility as discussed above. Without credibility, no meaningful soft power can be created nor can it be possibly implemented. As such, this thesis will look to examine how RBTH manages (or attempts to manage) its credibility throughout the course of a year where the "product" (Russia) that it is attempting to sell becomes fairly toxic in the minds of many of its intended readers and certainly within the larger context of public opinion in the United States. Objectivity (or the perception of some level of objectivity) remains an important factor in the maintenance of credibility, especially during times of difficulty (as discussed above). The audience of RBTH in America is an intelligent, educated audience (discussed further in the Empirical Background chapter). By the very nature of the insert being inside an American newspaper, we know that the readers consume some

\footnotetext{
${ }^{37}$ Robert F Delaney and John S Gibson, American Public Diplomacy: The Perspective of Fifty Years. (Medford, Mass.: Tufts University, 1967), 31.

${ }^{38}$ Merriam Webster, "Definition of Propaganda," accessed February 19, 2015, http://www.merriamwebster.com/dictionary/propaganda.
} 
amount of that larger newspaper and the version of the news contained within it. As a result, any instance where the guise of objectivity is dropped will prove to be detrimental to the overall effectiveness of the insert as a cultivation tool for soft power. The balance between the appearance of objectivity and the inherent subjective nature of public diplomacy is at the heart of creating credibility, along with maintaining interest in what is being transmitted through whatever the medium might be. Without public interest, the raison d'être for RBTH vanishes. 


\title{
3. Empirical Background
}

\author{
3.1 The History of the Development of Russian/Soviet Soft Power and Public Diplomacy \\ The Soviet Union's Soft Power/Public Diplomacy
}

The Interwar Years

During the early years of the Soviet Union (1920s-1930s), cultural ties to the West were still fairly strong, and the Communist Part/state apparatus attempted to maintain and grow these relationships. These ties existed in part because of the large number of Russian revolutionaries (now Communist Party members) who had spent time in exile in Western and Central Europe, and who subsequently spoke the languages and understood the cultures, and perhaps most importantly, they still maintained contacts there. ${ }^{39}$ One of the primary benefits of these relationships for the Communist Party/state was the notoriety of some of these men, which provided the state with excellent references and fostered an air of legitimacy for many of the Communist Party/state's early actions when these men would simply lend their support to these actions. ${ }^{40}$ For this reason, the relationships were initially deemed very important to the Communist Party/state, but eventually the distinction between internal and external threats resulted in distrust and animosity toward these relationships, especially in the 1930s, when

\footnotetext{
${ }^{39}$ Michael David-Fox, "The Fellow Travelers Revisited: The 'Cultured West' through Soviet Eyes," The Journal of Modern History 75, no. 2 (June 1, 2003): 307.

${ }^{40}$ Michael David-Fox, “From Illusory 'Society' to Intellectual 'Public': VOKS, International Travel and Party: Intelligentsia Relations in the Interwar Period," Contemporary European History 11, no. 1 (February 1, 2002): 7-8.
} 
paranoia and purges eliminated many of these previously established relationships and the credibility that they embodied. ${ }^{41}$

In order to foster, maintain, and grow these and other cultural ties and relationships, the Soviet Union in 1925 created the "All-Union Society for Cultural Relations with Foreign Countries" (Всесоюзное общество культурной связи с заграницей), which is better known as VOKS. ${ }^{42}$ This organization was responsible for a wide variety of cultural affairs both foreign and domestic. According to Michael David-Fox, "VOKS coordinated a vast and variegated set of responsibilities that combined "internal" and "external" concerns and activities. Abroad, it managed the "societies of friends" of the Soviet Union, as the burgeoning number of cultural friendship societies were informally called; gathered information on public opinion and intellectual trends; published widely circulated bulletins on Soviet cultural life; and supplied the press with information, articles, and photographs. At home, it received foreign intellectual visitors and arranged their contacts and tours within the Soviet Union; managed cultural, scientific, and book exchanges; and engaged the domestic intelligentsia for its various activities and publications."43 The many duties encompassed in one large organization were actually the result of a merger between a variety of different committees and other organizations that were aimed at providing guides and other help to aid workers in the early years of the 1920 s with most notable of these committees being the Central Executive Committee (TsIK) Commission on Foreign Aid. ${ }^{44}$

\footnotetext{
${ }^{41}$ David-Fox, "The Fellow Travelers Revisited," 306-307.

42 Ibid., 307.

${ }^{43} \mathrm{lbid}$.

${ }^{44}$ Ibid., 308.
} 
TslK was led by Olga Davidovna Kameneva, who was the sister of Lev Trotsky and the first wife of Lenin's deputy Lev Kamenev, and she eventually became the first director of VOKS. ${ }^{45}$ TsIK was tasked with coordinating the activities of foreign aid workers that Lenin's government reluctantly accepted during the Russian Civil War. ${ }^{46}$ In order to effectively do this, Kameneva and TsIK assigned guides to help the aid worker. During the Civil War, many of these guides were by necessity not communist and held independent opinions due to the fact that they needed to be highly educated and highly skilled in foreign languages, and many of them also happened to be Jewish. ${ }^{47}$ After the end of the Civil War and the creation of VOKS, these guides began to face increased scrutiny for their ideals and conduct, which eventually led to Kameneva instituting a new training program for guides that would focus on "political literacy" in $1927 .{ }^{48}$

Over the subsequent years, these guide training programs began to train the tour guides not only how to be politically sensitive toward the Soviet Union's goals, but they also faced pressure towards "proletarianization and "Bolshevization" as did Soviet education as a whole. They were renamed "Communist Courses for Guides" and all of the fifty students were Communist Youth League or party members." ${ }^{49}$ All of these changes came as a byproduct of "Stalin's Great Break," and these issues mirrored much of the political turmoil and paranoia that was characteristic of the late 1920s and 1930s in the Soviet Union. ${ }^{50}$ The leadership of

\footnotetext{
45 Ibid., 10; 308; Emily Lygo, "Promoting Soviet Culture in Britain: The History of the Society for Cultural Relations between the Peoples of the British Commonwealth and the USSR, 1924-1945," The Modern Language Review 108, no. 2 (April 1, 2013): 573, doi:10.5699/modelangrevi.108.2.0571.

${ }^{46}$ David-Fox, "The Fellow Travelers Revisited," 308-309.

${ }^{47}$ Ibid., 311.

${ }^{48} \mathrm{Ibid} ., 312$.

${ }^{49} \mathrm{lbid}$.

${ }^{50}$ Ibid., 312-314.
} 
VOKS reflected these changes and the nature of the times. Despite her husband and brother's falls from power in 1927, Kameneva was able to last three more years before she was removed from office in $1930 .{ }^{51}$ She was replaced by an Old Bolshevik named Fedor Nikolaevich Petrov, who had formerly worked in the Main Directorate for Scientific, Artistic, Museum, Theatrical, and Literary Institutions and Organizations, which was a part of the People's Commissariat for Education, and signaled the leadership's intention for the organization to follow the party line. ${ }^{52}$ Petrov lasted until 1934 when he was replaced by Alexander Arosev, who was a former Ambassador to Czechoslovakia and a long-time friend of Vyacheslav Molotov. ${ }^{53}$ Arosev was arrested in 1937 during the early stages of the Great Terror, and then he was replaced by the filmmaker Viktor Fedorovich Smirnov, who would remain in charge until $1940 .{ }^{54}$ The chaotic nature of the leadership was clearly reflected in the manner with which the Soviet guides they oversaw reacted. During the course of the 1930 s guides increasingly became combative and defensive with foreign visitors, and censored themselves and the reports that they were required to submit to the secret police on the nature of the questions these visitors asked along with their own responses in order to save themselves from scrutiny. ${ }^{55}$

Despite these pressures and the all-consuming paranoia of the times, many of these foreign travelers presented a "rosy picture" of the Soviet Union, which helped to foster goodwill with organizations in their home countries. ${ }^{56}$ Many of these travelers belong to socalled "fellow travelers clubs" or to other organizations sympathetic to the Soviet Union. One

\footnotetext{
51 Ibid., 320.

52 Ibid.

53 Ibid., 321.

54 Ibid.

55 Ibid., 313-319.

56 Ibid., 318-321.
} 
such organization was the British Society for Cultural Relations between the Peoples of the British Commonwealth and the USSR (SCR). The organization organized tours to the Soviet Union and wrote sympathetic articles and pamphlets about the Soviet Union and the communist cause. It also organized other cultural and political events and initiatives in London. ${ }^{57}$ These organizations worked in close coordination with VOKS, but the actual nature of this relationship was more a cooperation, and less a direct channel for propaganda, according to Emily Lygo. ${ }^{58}$ Lygo states that "although the SCR was a pro-Soviet organization, its enthusiastic presentation of Soviet culture was not so much the result of Soviet manipulation behind the scenes as a reflection of the enthusiasm for the USSR that active members nurtured for a wide variety of reasons." 59 Even during the late 1930s and the show trials and rumors of the great terror, membership in the club did not suffer. ${ }^{60}$ The SCR would remain a source for positive news about the Soviet Union and its developments throughout World War II. ${ }^{61}$ In contrast, Michael David-Fox argues that the Soviet mindset began to become distorted due to these interactions and that eventually the Soviet leadership would see in these writings the notion that the Soviet Union was superior to the West, just as many of the fellow travelers in the late 1930 s would begin to see the Soviet Union as inferior to the West. ${ }^{62}$ As a result, DavidFox argues that the Soviet Union and VOKS adopted a xenophobic stance that was born out of

\footnotetext{
57 Lygo, "Promoting Soviet Culture in Britain," 571-53.

58 Ibid., 572.

59 Ibid.

60 lbid., 592.

61 Ibid., 595-596.

62 David-Fox, "The Fellow Travelers Revisited," 333-334.
} 
this sense of superiority, along with the distrust of foreigners that sprang from the paranoia that was central to this period of Soviet history. ${ }^{63}$

The nature of the Soviet Union's attempts at fostering goodwill and soft power during the interwar period were initially somewhat successful, but ultimately their attempts would fail due to a few main reasons. In order to evaluate this, Nye's statement ("[t]he soft power of a country rests primarily on three resources: its culture (in places where it is attractive to others), its political values (when it lives up to them at home and abroad), and its foreign policies (when they are seen as legitimate and having moral authority") must be reapplied. ${ }^{64}$ In the case of the interwar Soviet Union, its culture was attractive to others, but its actions at home and abroad, the projection of its political values and foreign policy, did little to foster goodwill or boost Soviet soft power. The SCR may have stood by the Soviet Union despite the MolotovRibbentrop pact and the Great Terror, but much of the rest of the left wing in Britain abandoned its support of the Soviet Union because of these and other similar actions. ${ }^{65}$ In addition, many of the fellow travelers eventually turned on the Soviet Union, due to the many inconsistencies and failings that they witnessed on the ground in the Soviet Union. In the end, the Interwar Soviet Union's attempts at soft power failed because of the failure of the Soviet Union's leadership to live up to the ideals that it preached, but it was also clearly helped along by the chaotic nature of both the political order in Europe at the time and the monumental task of rapid industrialization that was underway in the Soviet Union during this period.

\footnotetext{
63 Ibid., 334-335.

${ }^{64}$ Nye, "What China and Russia Don't Get About Soft Power."

${ }^{65}$ Lygo, "Promoting Soviet Culture in Britain," 592-593.
} 
The Post-War Years and the Cold War

VOKS remained in existence until 1958 when it was replaced by the "Union of Soviet Societies for Friendship and Cultural Relations with Foreign Countries" (SSOD) (Союз советских обществ дружбы и культурной связи с зарубежными странами). ${ }^{66}$ During the early years of the Cold War before this transition, there were still some small level of cooperation and cultural exchange for VOKS, including the Bolshoi Theater's ballet company visiting Britain, however, the contentious nature of the early Cold War, including the Churchill's "Iron Curtain" speech, the Berlin Blockade, the Korean War, and the House Un-American Activities Committee, resulted in the Soviet withdrawal from most attempts at cultural exchange with the West and vice versa. ${ }^{67}$ As a result, the Soviet Union focused much of its attention for spreading soft power by looking at its own empire and constituent states along with third world countries. In essence this is what led to the change in name and strategy of the SSOD. According to the Great Soviet Encyclopedia, the SSOD was a:

union consist[ing] of 63 friendship societies, assigned to deal with various countries, including 12 socialist countries. It includes the USSR-France, USSR-Great Britain, USSRFinland, and USSR-Italy societies, the Society of Soviet-Indian Cultural Relations, and the USSR-Arab Republic of Egypt Friendship Society. Other societies include associations for friendship and cultural relations with Arab, African, and Latin-American countries, 11 associations and sections for scientists and cultural workers, 14 republic societies, and six branches in cities of the RSFSR (Leningrad, Volgograd, Irkutsk, Sochi, Tol'iatti, and Khabarovsk). The Association for Exchange Between Soviet and Foreign Cities is also a member of the union. The union's friendship societies include 25,000 enterprises, kolkhozes, sovkhozes, educational institutions, and scientific and cultural agencies. More than 50 million people participate in the union. ${ }^{68}$

\footnotetext{
${ }^{66}$ A. M Prokhorov, Great Soviet encyclopedia. (New York: Macmillan, 1973).

${ }^{67}$ Larraine Nicholas, "Fellow Travellers: Dance and British Cold War Politics in the Early 1950s," Dance Research: The Journal of the Society for Dance Research 19, no. 2 (December 1, 2001): 84-86, doi:10.2307/1290977.

68 Prokhorov, Great Soviet encyclopedia.
} 
In addition, the union maintained two newspapers (a daily and monthly version) that aimed at bringing news of achievements of the Soviet Union to people around the world. ${ }^{69}$ Unfortunately, there has been very little scholarship investigating the activities of these organizations and their effectiveness. However, an issue that must be highlighted is the "voluntary" nature of these "friendship societies." 70 At the heart of this issue from a soft power perspective is that these were largely not voluntary friendship societies, and although they were possibly intended to mirror Western public diplomacy efforts, they were essentially instruments of propaganda. As such, they received little to no soft power benefits from these organizations.

The Soviet Union attempted other activities that were aimed at fostering goodwill toward the Soviet Union around the world (especially the Third World) like financing construction and giving aid. The construction of the Anwar Dam could be seen as such an effort, along with the creation of a "Friendship University" in Congo. However, most of these efforts resulted in little noticeable or at least documented changes. Ultimately, the totalitarian nature of the Soviet Union and the corresponding nature of the governments that it fostered, left little room for true soft power development. As Nye puts it, "The Soviet Union once had a good deal of soft power, but it lost much of it after the invasion of Hungary and Czechoslovakia. Soviet soft power declined even as its hard economic and military resources continued to grow. Because of its brutal policies, the Soviet Union's hard power actually undercut its soft power." 71

\footnotetext{
${ }^{69} \mathrm{lbid}$.

$70 \mathrm{lbid}$.

${ }^{71}$ Nye, Soft Power, 9.
} 


\subsection{Post-Soviet Soft Power and Public Diplomacy}

After the collapse of the Soviet Union, the ideologically driven entities of the Soviet Union's failed public diplomacy/soft power effort were disbanded. In their place, the Russian Federation has created a variety of different entities that act in a relatively independent fashion from one another. Each entity has its own goals and financial structure. The main organizations that are focused on public diplomacy and/or soft power are Rossotrudnichestvo, the Russkiy Mir Foundation, the Valdai International Discussion Club, the Alexander Gorchakov Public Diplomacy Fund, the Russian International Affairs Council, the Rossiya Segodnaya news agency, the $R T$ news channel, and Russia Beyond the Headlines.

\section{Rossotrudnichestvo}

Rossotrudnichestvo is officially called "the Federal Agency for the Commonwealth of Independent States, Compatriots Living Abroad and International Humanitarian Cooperation" (Федеральное агентство по делам Содружества Независимых Государств, соотечественников, проживающих за рубежом, и по международному гуманитарному сотрудничеству). It is a part of the Ministry of Foreign Affairs. According to article 100 of the 2013 Concept of the Foreign Policy of the Russian Federation, Rossotrudnichestvo "participates in elaborating proposals and implementing the foreign policy of the Russian Federation in the field of assisting international development, providing international humanitarian cooperation, supporting Russian compatriots living abroad, strengthening the position of the Russian 
language in the world, and developing a network of Russian scientific and cultural centers abroad."72

Rossotrudnichestvo is the official government agency tasked with leading Russia's "public diplomacy."73 According to its website, "[public diplomacy] involves all kinds of interactions with civil society and foreign countries' public, giving the unique capacity for enhancing the state's international relations." ${ }^{74}$ The website continues by laying out the manner with which the organization carries out its public diplomacy mission by stating that:

public diplomacy includes such elements as non-governmental organizations and communities, 'twin cities' contacts, social and political activities, international nongovernmental organizations... Not only the public diplomacy in the international humanitarian cooperation should facilitate the further creation of positive image of Russia, but it should also promote the implementation of the specific country's interests. Rossotrudnichestvo fruitfully cooperates with such non-governmental organizations as 'Russian World' Fund, Russian Public Chamber, St. Andrew the FirstCalled Foundation, 'Russian Overseas' Library Foundation, Russian Culture Fund, International Russian Compatriots Fund, Theatre Union of the Russian Federation, International Council of Museums, 'Twin Cities' International Association, Moscow Friendship Communities Fund, St. Petersburg International Cooperation Association, etc. $^{75}$

Rossotrudnichestvo was created by presidential decree in 2008. Its main function is

promoting Russia in the former Soviet Republics, and it has cultural centers in all of the former

Soviet Republics except for the three Baltic States, which have refused to sign agreements with the Russian government that would allow for their establishment. ${ }^{76}$ Rossotrudnichestvo has also expanded around the world with cultural centers in Washington DC, Beijing, London, and

\footnotetext{
72 Ministry of Foreign Affairs of the Russian Federation, "MFA of Russia | 02/18/2013 | Concept of the Foreign Policy of the Russian Federation," accessed February 18, 2015, http://www.mid.ru/brp_4.nsf/0/76389FEC168189ED44257B2E0039B16D.

73 Ministry of Foreign Affairs of the Russian Federation, "Россотрудничество | Rossotrudnichestvo," accessed February 20, 2015, http://rs.gov.ru/.

74 Ibid.

75 Ibid.

76 Ibid.
} 
fifty-six other locations, along with "representative offices" in seventy-seven countries. ${ }^{77}$ These centers and offices are tasked with promoting Russian language and culture, and some are located in embassies and consulates, but most are in rented accommodations. ${ }^{78}$ For all intents and purposes, Rossotrudnichestvo is the main driving force behind Russian public diplomacy under the Western definition.

The Russkiy Mir Foundation

The Russkiy Mir Foundation was established by presidential decree in 2007 with the express purpose of "promoting the Russian language, as Russia's national heritage and a significant aspect of Russian and world culture, and supporting Russian language teaching programs abroad."79 The Foundation is a joint project of the Ministry of Foreign Affairs and the Ministry of Education and Science, and according to its website, it is funded by both state and private funds. ${ }^{80}$ The Russkiy Mir Foundation is headed by Vyacheslav Nikonov, who is the Dean of History and Political Science at the International University in Moscow. According to its website, "[t]he Foundation's Board of Trustees consists of prominent Russian academics, cultural figures, and distinguished civil servants." 81 The website states that the Foundation is meant "to promote understanding and peace in the world by supporting, enhancing and encouraging the appreciation of Russian language, heritage and culture." 82 Similar to

\footnotetext{
$77 \mathrm{lbid}$.

${ }^{78} \mathrm{lbid}$.

${ }^{79}$ Russkiy Mir Foundation, “Russkiy Mir Foundation,” accessed February 20, 2015, http://russkiymir.ru/en/.

${ }^{80} \mathrm{lbid}$.

${ }^{81} \mathrm{lbid}$.

${ }^{82} \mathrm{lbid}$.
} 
Rossotrudnichestvo, the Russkiy Mir Foundation has a specific goal designed for "Russian compatriots" outside of Russia. "Russkiy Mir reconnects the Russian community abroad with their homeland, forging new and stronger links through cultural and social programs, exchanges and assistance in relocation." 83 The Russkiy Mir Foundation has 83 centers in 41 countries, including 4 in Russia, 1 in Washington, D.C. and 1 in New York City. ${ }^{84}$

\section{Valdai International Discussion Club}

The Valdai International Discussion Club was founded in 2004. According to the club's website, "[t]he club's goal is to promote dialogue between Russian and international intellectual elites, and to make an independent, unbiased scientific analysis of political, economic and social events in Russia and the rest of the world." 85 The club claims that over 800 scholars and other representatives from almost 50 countries, including professors at Harvard, Columbia, Georgetown and Stanford, have participated in club activities. ${ }^{86}$ The website is vague about the nature of its funding, especially before 2011. In 2011 a non-profit organization was established in order to expand "its activities to new areas, including research and outreach work, regional and thematic programs." ${ }^{87}$ In 2014, the website simply says that "the Foundation for Development and Support of the Valdai Discussion Club assumed all responsibility for the club's projects.

\footnotetext{
83 Ibid.

84 Ibid.

${ }^{85}$ Valdai International Discussion Club, "Valdai - About," accessed February 20, 2015, http://valdaiclub.com/about/.

86 Ibid.

87 Ibid.
} 
The Foundation was established by the Council on Foreign and Defense Policy, the Russian International Affairs Council, the Moscow State Institute of International Relations (University) and the National Research University - Higher School of Economics." 88 According to its website, the Council on Foreign and Defense Policy is an independent NGO established in 1992 that works closely with the Russian government and is made up of high-ranking public and government officials, heads of business associations, prominent businessmen, the militaryindustrial complex, academics and media representatives. ${ }^{89}$ According to its website, the Russian International Affairs Council is a non-profit academic and diplomatic think tank that was established in 2010 by the Ministry of Education and Science and the Ministry of Foreign Affairs (discussed further later in this chapter). ${ }^{90}$ According to its website, the Moscow State Institute of International Relations is a university with a focus on diplomatic training that gives the impression of being an independent public university, except for the fact that its board of trustees is chaired by Sergei Lavrov, Minister of Foreign Affairs of the Russian Federation, and much of the rest of the board are oligarchs and ministers of other government ministries. ${ }^{91}$ Given this, the Institute is at the very least closely tied to the government. According to its website, the National Research University - Higher School of Economics is a privately created and privately funded university with links to universities across Europe. ${ }^{92}$ The school does have a "supervisory council" that is filled with government officials and a few oligarchs, but

\footnotetext{
88 Ibid.

${ }^{89}$ Council on Foreign and Defense Policy (Совет по внешней и оборонной политике), “О Совете | Совет По Внешней И Оборонной Политике," accessed February 20, 2015, http://svop.ru/about/.

${ }^{90}$ Russian International Affairs Council, "RIAC :: General Information," accessed February 20, 2015, http://russiancouncil.ru/en/about-us/what_is_riac/.

${ }^{91}$ Moscow State Institute of International Relations, “About MGIMO," accessed February 20, 2015, http://english.mgimo.ru/about-mgimo.

${ }^{2}$ National Research University Higher School of Economics, "History - National Research University Higher School of Economics," accessed February 20, 2015, http://www.hse.ru/en/info/hist/.
} 
according to the school's website, the supervisory council plays no role in the governance of the university. ${ }^{93}$

Despite the obvious attempts to distance the Valdai International Discussion Club from a sense of government control, the club clearly has at least close ties with the government in a variety of fields. In addition to the aforementioned links to the funding of the club, its annual conferences have been attended by Putin, and he has given a speech at each one. Certainly, the Valdai club should not be considered a simple mouthpiece for government propaganda. The level of international cooperation is impressive, and the value of such an organization of academic cooperation is certainly valuable. However, the club can be viewed essentially as an extension of the wider effort of the Russian Federation to cultivate and expand its soft power resources around the globe.

\section{Alexander Gorchakov Public Diplomacy Fund}

The Alexander Gorchakov Public Diplomacy Fund was established in 2010 by presidential decree along with the Russian International Affairs Council, which the Fund works with in close cooperation. The council is named after the famous $19^{\text {th }}$-century Russian diplomat Alexander Gorchakov. According to its website, which is riddled with English language problems, the Fund is tasked with "encouraging development of the public diplomacy field and supporting establishment of a favorable for Russia public, political and business climate."94

\footnotetext{
93 Ibid.

94 The Alexander Gorchakov Public Diplomacy Fund, “Mission and Goals - The Alexander Gorchakov Public Diplomacy Fund," accessed February 21, 2015, http://gorchakovfund.ru/en/about/mission/.
} 
Essentially, the Fund is involved in supplying aid and assistance to all aspects of the Russian public diplomacy effort. The Fund works with media, businesses, NGOs, and any other agency that requires or wishes for its support in order to promote themselves to foreign audiences. Typically, the Fund is involved in funding these efforts through grants. The Fund's board of trustees is again a veritable who's who of Russian foreign policy, including Lavrov and other government ministers and a variety of oligarchs. ${ }^{95}$ Furthermore, the partners of the Fund, as listed by the website, are the Russian International Affairs Council, the Russkiy Mir Foundation, Rossotrudnichestvo, and the Moscow State Institute of International Relations (MGIMO.) ${ }^{96}$

\section{Russian International Affairs Council}

The Russian International Affairs Council was established in 2010 by presidential decree along with the Alexander Gorchakov Public Diplomacy Fund. As mentioned above, the Russian International Affairs Council is a non-profit academic and diplomatic think tank that was established in 2010 by the Ministry of Education and Science and the Ministry of Foreign Affairs. According to its website, "RIAC activities are aimed at strengthening peace, friendship and solidarity between peoples, preventing international conflicts and promoting conflict resolution and crisis settlement. RIAC operates as a link between the state, scholarly community, and civil society in an effort to find foreign policy solutions to complex conflict issues." 97 The Council's activities are broken down into four categories: "research work and

\footnotetext{
95 Ibid.

96 Ibid.

${ }^{97}$ Russian International Affairs Council, "RIAC :: General Information."
} 
international expertise", "education and enlightenment", "communication and public activities", and "international activities."98

Each activity has individual goals and tasks associated with it. "Research work and international expertise" states that its "aim is to provide analyses and forecasts of global risks and opportunities for the benefit of Russian diplomacy, businesses, educational centers, public organizations, and their foreign peers." 99 To accomplish this work, the Council provides and carries out studies and surveys associated with "burning issues in world politics," funds academic studies to carry out these studies and analyze them, provides pundits with data and analysis, and provides translation services. ${ }^{100}$ All of this is claimed to be done in conjunction with think tanks. The "education and enlightenment" branch of the Council states that its "aim is to facilitate the training of career foreign policy workforce through integration into global educational environment."101 To accomplish this aim, the Council provides, organizes and funds a variety of educational courses and internships. The "communication and public activities" branch states that its "aim is to ensure interaction between representatives of various professional groups in the context of new challenges and opportunities emerging from modern global processes." 102 In order to accomplish this, the Council facilitates high-level discussions among international political leaders and Russian government officials and academics, along with organizing conferences and other events that facilitate such interactions. The "international activities" branch states that its "aim is to create favorable conditions for

\footnotetext{
98 Ibid.

99 Ibid.

100 Ibid.

101 Ibid.

102 Ibid.
} 
Russia's fastest integration into a global world by implementing multilateral network projects and initiatives." 103 To accomplish this, the Council provides assistance in dealing with foreign governments and businesses, analyzes foreign counterparts and potential partners, and provides any other assistance that might be required to Russian businesses or NGOs. Overall, the Council is a formidable and powerful advocate for all Russian interests in dealing with and understanding the situations that exist outside of Russia in order to streamline the process of integration and cooperation. The board of trustees of the council also includes the usual members of government and the oligarchy. The partners of the Council include every entity that is discussed in this chapter, as well as many others.

Rossiya Segodnaya

The Rossiya Segodnaya news agency was established in December 2013 by executive order. ${ }^{104}$ The creation of Rossiya Segodnaya ("Russia Today" in Russian, but that should not be confused with Russia Today, now $R T$, which is a separate entity) came as the result of a merger and/or dissolution of the old RIA Novosti news agency and the Voice of Russia radio station, both of which were state-owned. ${ }^{105}$ Curiously, Rossiya Segodnaya launched a replacement for RIA Novosti called Sputnik a month before Rossiya Segodnaya was actually founded. ${ }^{106}$ In

\footnotetext{
103 Ibid.

${ }^{104}$ Russian Presidential Executive Office, "President of Russia," accessed February 21, 2015, http://eng.kremlin.ru/acts/6387.

105 Sputnik International, "RIA Novosti to Be Liquidated in State-Owned Media Overhaul / Sputnik International," accessed February 21, 2015, http://sputniknews.com/russia/20131209/185390572/Russia-Announces-StateOwned-Media-Overhaul.html.

${ }^{106}$ Sputnik International, “About Us - Sputnik International," accessed February 21, 2015, http://sputniknews.com/docs/about/index.html.
} 
addition, Sputnik Radio was also similarly launched as a replacement for the Voice of Russia radio station. ${ }^{107}$ The two entities work in harmony and produce content that is "entirely geared toward foreign audiences" and is produced in many different languages including English and Russian. ${ }^{108}$ The stated aim of Sputnik is to "point the way to a multipolar world that respects every country's national interests, culture, history and traditions."109 In a different executive order but on the same day, the controversial journalist Dmitry Kiselev was named director of the new organization. ${ }^{110}$

As a new organization, information is relatively sparse with respect to nearly all aspects of its activities, including the content that it produces. The reasons for its creation are unclear as well. The executive order has little to say on the subject, and not enough time has passed for a clear retrospective look at the reasons for its founding. The international media has presented theories on the reason for its creation along with a healthy bit of criticism of the organization, its founding, and the new director. The international press reports that the decision was a political one that resulted from a conservative faction winning a battle against a liberal element led by former RIA Novosti Chief Editor Svetlana Mironyuk, who wanted to balance the organization's coverage and gain some level of independence. ${ }^{111}$ The same media

\footnotetext{
107 Ibid.

108 Ibid.

109 Ibid.

110 Russian Presidential Executive Office, "President of Russia."

111 Daniel Sandford, "Russian News Agency Closed down," BBC News, accessed February 21, 2015, http://www.bbc.com/news/world-europe-25299116; RFE/RL, “Putin Reorganizes State Media Into New Conglomerate," RadioFreeEurope/RadioLiberty, December 9, 2013, sec. Russia, http://www.rferl.org/content/russia-new-news-agency/25194336.html; Steven Lee Myers, "Without Notice, Putin Dissolves a News Agency," The New York Times, December 9, 2013, sec. World / Europe, http://www.nytimes.com/2013/12/10/world/europe/putin-scraps-kremlin-news-agencies.html; Steven Ennis, "Propaganda Fears as Putin Replaces News Agency," BBC News, accessed February 21, 2015, http://www.bbc.com/news/world-europe-25309139; Timothy Heritage, "Putin Dissolves State News Agency,
} 
reports contemplate whether the move will lead to increased propaganda and censorship, and criticizing the choice of Kiselev as the head of the new organization because of controversial comments and stances that he has made over the course of his career. Although the complete nature and role of the new agency largely remain to be seen, its predecessors provide a viable look at the possible nature of the agency, which is clearly meant to produce positive news stories about Russia.

RIA Novosti was created in 1941 two days after the Nazi invasion of the Soviet Union, by a decree of the USSR's Council of People's Commissars and the Communist Party Central Committee. ${ }^{112}$ The decree established the Soviet Information Bureau (Sovinformburo) that was responsible for covering news both at home and abroad. ${ }^{113}$ During the war, Sovinformburo was responsible for all frontline reporting, and it contained a department for propaganda as well. ${ }^{114}$ After the war, the agency was tasked with being the primary voice for the Soviet government abroad, and it was responsible for reporting on all aspects of Soviet domestic and foreign policy to an international audience. ${ }^{115}$ In 1961, the name of the agency was changed to the Novosti Press Agency. ${ }^{116}$ In 1990, the name of the agency was again changed to the Information Agency Novosti, and an additional aim was added to its agenda by the decree that stated the agency was "[t]o provide informational support for the USSR's state domestic and foreign policies and

\footnotetext{
Tightens Grip on Russia Media," Reuters, December 9, 2013, http://www.reuters.com/article/2013/12/09/usrussia-media-idUSBRE9B80I120131209.

${ }_{112}$ RIA Novosti, "About Us - The Russian News \& Information Agency RIA Novosti," accessed June 11, 2013, http://www.rianovosti.com/docs/about/novosti.html.

113 Ibid.

${ }^{114}$ Ibid.

115 Ibid.

116 Ibid.
} 
proceeding from the interests of the democratization of the mass media." 117 During most of the Soviet period, the organization had bureaus in 120 countries around the world. ${ }^{118}$ After the collapse of the Soviet Union, a new version of the agency was established by the Russian government that was based on and incorporated the old structure of the Soviet agency. ${ }^{119}$ During the 1990s, the Agency was expanded to include radio and television stations, and in 2005, RIA Novosti, as it was then known, helped to launch the Russia Today television network. ${ }^{120}$

The Voice of Russia radio station was created in 1929 under the name Radio Moscow..$^{121}$ For years the station broadcast content in foreign languages, including English. During the Soviet era, the station broadcast materials approved by the Soviet government. In 1993, President Boris Yeltsin reorganized the station and changed its name to the Voice of Russia. ${ }^{122}$ Today, the radio station broadcasts to 160 countries in 38 languages, including 18 states in the US. ${ }^{123}$

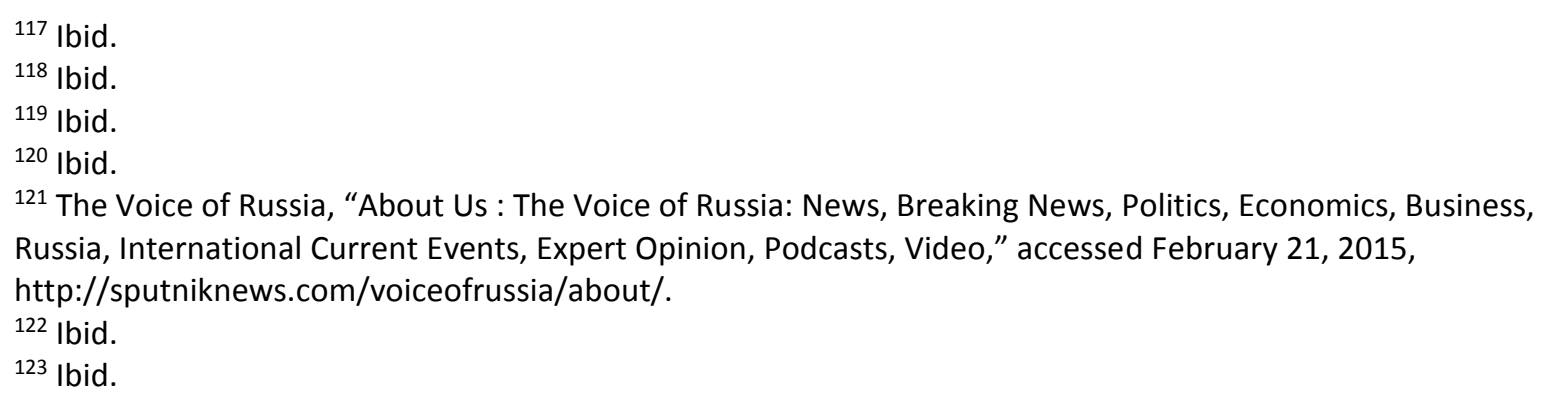


$R T$ was created in 2005 as Russia Today. It is a round-the-clock news network that is broadcast around the world in more than 100 countries. ${ }^{124}$ Originally, the network broadcasts were solely in English and Russian, but now there are Spanish and Arabic broadcasts as well. ${ }^{125}$ RT America is broadcast from Washington, DC, and it has specialized programs for its American audience. ${ }^{126}$ In addition to traditional broadcast television, $R T$ also has a large focus and presence on the internet, where its YouTube channel was the first to receive a billion views. ${ }^{127}$ $R T$ has come under considerable criticism from the press (discussed further below). However, the channel has also been nominated three times for an International Emmy award in the News category for its reporting on the Occupy Wall Street movement and hunger strikes of Guantanamo detainees. ${ }^{128} R T$ states that its mission is to "cover the major issues of our time for viewers wishing to question more and delivers stories often missed by the mainstream media to create news with an edge. RT provides an alternative perspective on major global events, and acquaints an international audience with the Russian viewpoint."129

\subsection{Russia Beyond the Headlines}

RBTH began to publish inserts in 2007 in the Washington Post and the Daily Telegraph. RBTH publishes print supplements (typically on a monthly basis) in 26 newspapers in 23 countries in 16 different languages, as well as maintaining 19 websites in 16 different languages

\footnotetext{
${ }^{124}$ RT, “About Us - RT,” accessed February 21, 2015, http://rt.com/about-us/.

125 Ibid.

${ }^{126}$ Ibid.

${ }^{127}$ Ibid.

128 Ibid.

${ }^{129}$ Ibid.
} 
that are updated regularly. ${ }^{130} \mathrm{RBTH}$ is a subsidiary of Rossiyskaya Gazeta, but the editorial staff is separate from Rossiyskaya Gazeta. ${ }^{131}$ Rossiyskaya Gazeta is owned completely by the Russian government, and it serves as the newspaper of record for the Russian Federation. ${ }^{132}$ In America, RBTH now includes supplements in the New York Times and the Wall Street Journal. Initially, the various supplements had different names, but as of April 2014, all English language supplements have been called "Russia Beyond the Headlines."133

RBTH's stated mission is to be "a link between Russian society and a foreign audience, offering its media platforms for a balanced and professional international dialogue."134 In order to accomplish this goal, "RBTH collects, selects and publishes in foreign languages topical reports about Russian politics, public life, culture, business, science, history and other areas that are usually not covered by foreign media for their domestic audiences."135 Most of the articles that RBTH publishes in its supplements are done by freelance writers specifically for RBTH, but they also draw from other press sources in Russia. ${ }^{136}$ All articles are edited by RBTH staff who are native speakers, and for the print supplements, the articles are further edited by a copy editor hired by the partner newspapers in order "to make sure that RBTH material complies with the editorial traditions, journalistic standards, rules and other specific features of

\footnotetext{
${ }^{130}$ Russia Beyond The Headlines, “Company | Russia Beyond The Headlines," accessed January 28, 2015, http://rbth.co.uk/about_us/company.

${ }^{131}$ Ibid.

132 Ibid.

133 Ibid.

${ }^{134} \mathrm{Ibid}$

135 Ibid.

${ }^{136}$ Ibid.
} 
the partner publications. As a rule, these copy editors are not members of the editorial staff of the partner newspapers."137

RBTH is funded primarily by Rossiyskaya Gazeta, but it also receives some funding from sponsorships and commercial advertising. ${ }^{138}$ RBTH compensates partner newspapers for publishing the supplements, as well as for other costs such as promotion of the supplements and for studying readership and feedback. ${ }^{139}$

As a part of their agreement with RBTH, the partner newspapers are required to do sociological and marketing research on the readership of the print supplements. ${ }^{140}$ These studies are meant to assess readers' awareness of the project and feedback on it. ${ }^{141}$ According to the RBTH website, these independent studies consist of 500-600 respondents who are asked about how often they read or skim through RBTH, how much time they spend reading it, which topics they are most interested in and which topics they would like to see covered in future issues, how they view the current state of affairs between their country and Russia, etc. ${ }^{142}$ RBTH posts some of the results of these studies on its website. The results of the surveys for the fourth quarter of 2013 for both the Washington Post and the Wall Street Journal are included on the website, but for some unknown reason, no results for the survey of its New York Times readers has been posted.

\footnotetext{
137 Ibid.

138 Ibid.

139 Ibid.

140 lbid.

141 lbid.

142 Ibid.
} 
The two available surveys provide an insight into the readership of these supplements.

The results for the Washington Post are as follows:

RBTH Readership -

Almost half (46\%) of The Washington Post readers have seen the RBTH print supplement in the last 6 months. $47 \%$ of RBTH supplement readers in The Washington Post spend more than 5 minutes engaging with it.

The RBTH Audience (Print) -

The RBTH audience are regular readers of the quality press and are affluent and well educated. They carry authority and impact in the community and demonstrate, through their consumption of RBTH, an appetite for objective and varied information about modern Russia. In the particular case of The Washington Post, 55\% of RBTH supplement readers are Male, $83 \%$ are $35+$ aged and $95 \%$ are educated to degree level or above.

Positive Evaluation of RBTH in The Washington Post -

$80 \%$ of those who read RBTH in print agreed that they would read it again. Two thirds of RBTH audience agree that the articles are well written (66\%) and contain new information (67\%). Almost three quarters (73\%) of The Washington Post supplement readers agree that it is well written. ${ }^{143}$

The results for the Wall Street Journal are as follows (as noted above, before April, 2014

the RBTH supplement for the Wall Street Journal was called "Russia Business Insight"):

RBTH Readership -

More than half of WSJ readers (55\%) have seen the RBTH print supplement in the last 6 months. Two thirds $(63 \%)$ of supplement audience have read at least two out of three issues of the supplement.

The RBTH Audience (Print) -

The Russia Business Insight audience are regular readers of the quality press and are affluent and well educated. They carry authority and impact in the community and demonstrate, through their consumption of RBTH, an appetite for objective and varied information about modern Russia. In the particular case of WSJ, 75\% of Russia Business Insight supplement readers are Male, 96\% are 35+ aged and $98 \%$ are educated to degree level or above.

Positive Evaluation of RBTH in WSJ -

Two thirds of Russia Business Insight audience agree that the articles are well written (66\%) and interesting (67\%) Almost three quarters (72\%) of WSJ supplement readers agree that it is easy for understanding. More than half of the The Russia Business Insight audience agree that it analyses issues in depth and logically. Almost half (46\%) of the WSJ RBTH audience agree that it is up to date with current trends, developments and thinking in their country and globally. ${ }^{144}$

143 Ibid.

144 Ibid. 
As the studies indicate, the readership of the RBTH supplements in both the Washington Post and the Wall Street Journal are substantive. Both groups tend to be well educated. The Wall Street Journal readers tend to be predominantly male, while the Washington Post tends to have a more balanced gender ratio. In addition, both sets of readers tend to have a favorable disposition towards the manner in which the supplements are written and the content that is contained within them. Unfortunately, data about what the readers think about the current state of affairs between Russia and the US is not available. Nor is there data from 2014, which could show how the readership and perception of the newspapers changed over the course of 2014 at a time of increased tensions between Russia and the United States, which would otherwise have been valuable for the sake of this thesis.

The number of readers is sizeable for both publications. For the Wall Street Journal, the readership numbers indicate that the RBTH supplements in 2013 were viewed by almost 750,000 people during the past six months based on average daily circulation (approximately $1,360,000) .{ }^{145}$ Out of that group, almost 470,000 readers have read two out of three issues of the supplement. ${ }^{146}$ The Washington Post has a much smaller circulation $(377,466)$ than the Wall Street Journal, but the Post's RBTH supplement would still have had almost 175,000 readers in the last six months. ${ }^{147}$ Despite having no data from the RBTH survey, the New York Times had an average circulation of 639,890 during the period of April-September 2013. ${ }^{148}$

\footnotetext{
145 Statista, "Wall Street Journal: Circulation 2014 | Statistic," Statista, accessed February 22, 2015, http://www.statista.com/statistics/193788/average-paid-circulation-of-the-wall-street-journal/. 146 Ibid.

147 Statista, "Washington Post: Circulation 2014 | Statistic," Statista, accessed February 22, 2015, http://www.statista.com/statistics/193818/average-paid-circulation-of-the-washington-post/. 148 Statista, "New York Times: Circulation 2014 | Statistic," Statista, accessed February 22, 2015, http://www.statista.com/statistics/193792/average-paid-circulation-of-the-new-york-times/.
} 
Ultimately, the readership for all publications is fairly high, and as the RBTH website states, the audience that it is targeted consists of "political, cultural, expert, business, and academic elites" that are "well-educated, well-to-do and socially active people."149 Thus, one of the central aims of this thesis is to study and analyze what messages are being transmitted to this audience.

\section{Credibility of RBTH}

The two main attempts at reaching an American audience directly through the news media ( $R T$ and RBTH) are relatively unique and similarly important to this thesis. The Russiangovernment-funded news outlet $R T$ has received its fair share of accusations throughout its entire time in existence, including claims of disinformation, biased reporting, propaganda, and various other similar claims. ${ }^{150}$ Although these various claims and issues are not the focus of this thesis, and as such they will not be discussed in depth, their existence and persistence is fundamental to the issue of credibility, because the same thing cannot be said for the American RBTH supplements, which are the focus of this thesis.

Since its initial inception in 2007, RBTH has received only mild criticism. The early criticism, such as a 2007 article posted in Slate Magazine, which is owned by The Washington

\footnotetext{
${ }^{149}$ Russia Beyond The Headlines, "Company | Russia Beyond The Headlines."

${ }^{150}$ Benjamin Bidder, "Putin Fights War of Images and Propaganda with Russia Today Channel," Spiegel Online, August 13, 2013, http://www.spiegel.de/international/business/putin-fights-war-of-images-and-propaganda-withrussia-today-channel-a-916162.html; Stephen Heyman, "A Voice of Mother Russia, in English," The New York Times, May 18, 2008, sec. Arts / Television, http://www.nytimes.com/2008/05/18/arts/television/18heym.html; Marcin Maczka, "The Propaganda Machine," Bi-Monthly Academic Magazine, New Eastern Europe, (July 9, 2012), http://www.neweasterneurope.eu/interviews/320-the-propaganda-machine; Julia loffe, "What Is Russia Today?," Columbia Journalism Review, accessed February 18, 2015, http://www.cjr.org/feature/what_is_russia_today.php; Michael Moynihan, "Russia's International News Channel RT Warps the Truth About the Syrian Uprising," Tablet Magazine, accessed February 18, 2015, http://tabletmag.com/jewish-news-and-politics/90971/disinformation; Brett LoGiurato, "RT Is Very Upset With John Kerry For Blasting Them As Putin's 'Propaganda Bullhorn,'” Business Insider, accessed February 18, 2015, http://www.businessinsider.com/john-kerry-rt-propaganda-bullhorn-russiatoday-2014-4; Michael Crowley, "Tit-for-Tat: Putin's Maddening Propaganda Trick," Time, May 1, 2014, http://time.com/84843/vladimir-putin-russia-propaganda/; Peter Pomerantsev, "How Russia Is Revolutionizing Information Warfare," Defense One, accessed February 18, 2015, http://www.defenseone.com/threats/2014/09/how-russia-revolutionizing-information-warfare/93635/.
} 
Post and is the publisher of the RBTH insert, focused on things like poor writing style or blanket accusations against the inserts for being propaganda without any real examples being cited. ${ }^{151}$ Later criticism, such as an article from 2012 for the political website American Thinker, criticized an RBTH article's coverage of the arrest and alleged torture of Leonid Razvozzhayev, and the semantics used in its coverage, yet this can be seen as more of a disagreement on the style of the reporting and less on its credibility. ${ }^{152}$ The other sparse but available criticisms come from opinion pieces in newspapers or similar items, such as an article in the Daily Telegraph in 2014 about the Ukrainian crisis, which typically called for the end of the newspaper's relationship with RBTH due to a series of policy and other conflicts between Russia and the West. ${ }^{153}$ As a whole, the criticism and complaints lodged against RBTH are far from similar to the accusations lobbied against $R T$. Instead, the majority of accusations against RBTH can and should be seen as either the stereotyping of lazy journalists/critics, or the run-of-the-mill criticisms that any newspaper receives on a regular basis.

This thesis argues that the RBTH supplements in America have maintained a level of credibility for three reasons. First, these supplements overcame the initial barriers that Russian media typically face when attempting to reach an American audience (i.e. propaganda claims) by attaching itself to and imitating the style of highly respected American newspapers. Unlike $R T$ which had to create an entirely new platform that wasn't tied to any traditional, established

\footnotetext{
151 Jack Shafer, "Hail to the Return of Motherland-Protecting Propaganda!," Slate, August 30, 2007, http://www.slate.com/articles/news_and_politics/press_box/2007/08/hail_to_the_return_of_motherlandprotecti ng_propaganda.html.

152 Kim Zigfeld, “Articles: Misreporting on Russia," accessed February 18, 2015, http://www.americanthinker.com/2012/12/misreporting_on_russia.html.

153 Roy Greenslade, "Telegraph to Continue Publishing Russian Propaganda Supplement," The Guardian, accessed February 18, 2015, http://www.theguardian.com/media/greenslade/2014/jul/29/dailytelegraph-russia.
} 
group, the RBTH supplements were able to use this aura of respectability to have the targeted audience take the time to read the inserts and evaluate them for their own merit.

Second, the quality and merit of the inserts were and are top notch. As discussed above, by adopting the style of American newspapers, and specifically that of the newspaper to which the supplement is attached, allows for the reader to have an intrinsic sense of trust based on the familiarity of the writing. As discussed in the theoretical section, soft power analysts agree that in order for a soft power cultivation tool to be useful, it must engage the subject audience on its terms and in a manner to which it is familiar. ${ }^{154}$

Third, the RBTH supplements, while being targeted and typically, systematically positive about Russia, are willing and able to criticize aspects of Russian culture, politics, society, and economics. As Nye states, "It is sometimes domestically difficult for the government to support presentation of views that are critical of its own policies. Yet such criticism is often the most effective way of establishing credibility." ${ }^{155}$ The American RBTH supplements certainly heed this advice in a variety of ways (discussed further in the data and analysis chapter).

Ultimately, the RBTH supplements have been able to establish a sustained readership by maintaining as close to journalistic integrity as a soft power/public diplomacy tool is able to do. This is not to discount the fact that the content of these supplements has been carefully selected and crafted in order to convey a message directly to their intended audiences. The supplements sometimes share articles or aspects of articles with one another; however, each supplement is intended for its own specific audience, and it is crafted in order to speak to that

\footnotetext{
154 Nye, "Public Diplomacy and Soft Power," 103.

155 Ibid., 106.
} 
particular audience. This thesis analyzes how the various messages that these supplements are conveying grow, change, and interact with each other over time. In addition, this thesis analyzes how these messages interact with current events and the devolving relationship between Russia and the US.

\subsection{Anti-Russian Bias in American Media}

One of the foremost reasons behind the creation of supplements like RBTH is the Russian government's belief of the American media's bias toward Russia in its reporting. The supplements are certainly soft power/public diplomacy tools that wish to help to create a better image of Russia in American public opinion along with facilitating the advancement of Russian business and other interests in the United States. As discussed above, soft power and public diplomacy are designed and undertaken with the hope that a state will be able to attract key actors other countries to want what it wants. This attractiveness is made all the more difficult when consistent negative biases are believed to exist in the media of the targeted countries. Certainly, no state has the responsibility to openly allow a foreign state to attempt to persuade their citizens to act in the interest of that foreign state. However, overcoming this perceived bias is central to the aims of the Russian government in producing the American RBTH supplements. As stated above, the RBTH mission, according to its website, is to foster "balanced and professional international dialogue" and to cover stories about Russia "that are usually not covered by foreign media for their domestic audiences."156 A primary research

\footnotetext{
${ }^{156}$ Russia Beyond The Headlines, "Company | Russia Beyond The Headlines."
} 
question for this thesis involves how the RBTH supplements attempt to challenge these perceived media biases and stereotypes.

The issue of bias toward Russia within the American press has been studied and allegedly confirmed in a variety of different academic articles and studies, which the Russian government points to in order to show bias in the American media. ${ }^{157}$ In Katchanovski and Morley's study, "The Politics of U.S. Television Coverage of Post-Communist Countries," the authors examined the television news broadcasts on $A B C, C B S$, and NBC about Russia from 1998 to 2009 . They concluded that these "broadcasts... were dominated by negative stories, such as tense relations with the United states, crime and criminals, spying and secret services, and undemocratic developments in Russia." 158 They also found that "newly invented stereotypes that associate Russia with children adopted in the United States, mail-order brides, sex slaves, and oligarchs" were far more prevalent in the broadcasts than traditional images of "vodka and alcoholism, cold climate and Siberia, bears, and Russian roulette." 159 This is significant because it means that the stereotypes about Russia are evolving and becoming related to hot button issues between the two countries.

In Andrei Tsygankov's article "Blaming Moscow," he studied the history and influence of the "the Anti-Russian Lobby" in American politics and foreign-policy planning in relation to the U.S. reaction to the Russo-Georgian War of 2008. He later expanded this research into a larger

\footnotetext{
${ }^{157}$ Ivan Katchanovski and Alicen Morley, "The Politics of U.S. Television Coverage of Post-Communist Countries," Problems of Post-Communism 59, no. 1 (January 2012): 15-30, doi:10.2753/PPC1075-8216590102; Andrei P. Tsygankov, "Blaming Moscow: The Power of the Anti-Russia Lobby," Global Dialogue 11 (Winter 2009): 64-73; Anatol Lieven, “Against Russophobia," World Policy Journal 17, no. 4 (December 1, 2000): 25-32; Pippa Norris, "The Restless Searchlight: Network News Framing of the Post-Cold War World," Political Communication 12 (December 1995): 357-70.

158 Katchanovski and Morley, "The Politics of U.S. Television Coverage of Post-Communist Countries," 29. 159 Ibid., 30.
} 
book on the subject titled Russophobia: Anti-Russian Lobby and American Foreign Policy. ${ }^{160}$ In the article, he argues that "besides feeding to the general public the highly distorted image of Russia as a power that is relentlessly autocratic, has no regard for civilian life, and is interested only in restoring its domination in the Caucasus, the anti-Russian groups have contributed to a hardening of official US policy on Russia."161 Although Tsygankov did not conduct an empirical study of the "lobby" or its activities per se, his conclusions support the findings of other studies that did conduct such research. Similarly, Anatol Lieven's article "Against Russophobia," details the actions and manifestations of Russophobic forces within America, and similarly he applies it to a study of media representations. ${ }^{162}$

It is clear that the U.S. media portrays Russia in a negative light. For anyone that has watched American late night talk shows, it is clear that Russia is portrayed negatively. However, public opinion polls show that the prevailing perception of Russia among the general population prior to the Ukrainian crisis was fairly mixed, although still largely negative. In a Pew Research Center "Global Attitudes \& Trends" poll, the responses from Americans about Russia were generally favorable (those that answered "very favorable" and "somewhat favorable") with the numbers rising from $42 \%$ in 2007 to $49 \%$ in $2012 .{ }^{163}$ While during the same period, those in the US population with an unfavorable (those that answered "very unfavorable" and "somewhat unfavorable") view of Russia rose between $35 \%$ in 2007 and $40 \%$ in $2012 .{ }^{164}$ These

\footnotetext{
${ }^{160}$ Andrei P Tsygankov, Russophobia: Anti-Russian Lobby and American Foreign Policy (New York: Palgrave Macmillan, 2009).

161 Tsygankov, "Blaming Moscow," 72.

162 Lieven, "Against Russophobia."

163 Pew Research Center, "Global Indicators Database," Pew Research Center's Global Attitudes Project, accessed February 18, 2015, http://www.pewglobal.org/database/. 164 Ibid.
} 
numbers indicate that more Americas were inclined to express a positive opinion of Russia before the Ukrainian crisis, yet there was still a sizeable group with views that were unfavorable towards Russia. In the 2014 poll, Americans with a generally favorable opinion of Russia fell dramatically to $19 \%$, while those with a generally unfavorable opinion of Russia shot up to $72 \% .{ }^{165}$ This change is not especially surprising. However, the media in America has certainly had an effect on this rise in anti-Russian feelings in America. It is in this context that RBTH and its sister organizations have had to react over the course of 2014. This thesis evaluates this response in a variety of ways through the lens of RBTH.

165 Ibid. 


\section{Research Questions}

As a result of my theoretical approach and empirical background research I posit eight points for establishing the basis of my analysis: (1) that the soft power and public diplomacy cultivation activities of the Russian Federation are a joint venture undertaken by the government of the Russian Federation through both official government agencies and government-owned media operations and think tanks; (2) this joint venture is accomplished in a variety of ways including through the use of supplements in major foreign newspapers; (3) that RBTH is a manifestation of this joint venture; (4) RBTH hopes to engage with the readers of the Washington Post, Wall Street Journal and the New York Times in a familiar manner; (5) there is a consistent bias toward Russia in the American media, and RBTH is a part of the Russian response to this by challenging the prevailing narrative; (6) 2014 was a particularly difficult year for the advancement of Russian soft power in the United States of America due to the crisis in Ukraine; (7) that effective soft power/public diplomacy cultivation involves more than just politics or media-bias correction activities; and (8) the basis of a successful, mediabased soft power/public diplomacy cultivation strategy, such as RBTH, is credibility, which results from a mix of factors including criticism of the sponsoring government engaging in the activity.

Consequently, several research questions arise and the answers to them drawn from the available evidence form the basis of my thesis. What is the nature of the content produced for RBTH? How has this changed over time? How does RBTH deal with the Ukrainian crisis? Does RBTH remain credible as described above? 


\section{Methodology}

The probing of my research questions will be carried out through a combination of a quantitative content analysis and a qualitative analysis. The two aspects will work together in order to be able to identify areas of interest for the producers of RBTH and the frequency and prominence of their appearance over time, and to analyze trends in these data points.

Furthermore, the tone employed and strategies used by the authors will be identified, codified, and ultimately analyzed in a similar manner to the areas of interest mentioned above.

\subsection{Methods}

At the heart of the analysis will be a quantitative content analysis. At the heart of a quantitative content analysis is the ability to manage and analyze a large amount of unstructured data over a period of time. ${ }^{166}$ In my research, I will use the quantitative content analysis in two ways. The first aspect will be a straightforward coding system that will allow for the general information of an article to be systematically catalogued. The information that will be gathered from this process will be to find for each article these criteria: (1) the date; (2) the genre; (3) the publication that it appears in [WSJ, WP, NYT]; (4) the author; (5) the length; (6) the location within the supplement [what page]; (7) the prominence of the article on the page(i.e. whether it is the main article on the page; a secondary article on the page, which

\footnotetext{
${ }^{166}$ Bertram Scheufele, “Content Analysis, Quantitative," The International Encyclopedia of Communication, Blackwell Reference Online (Blackwell Publishing, n.d.), <http://www.communicationencyclopedia.com/subscriber/tocnode.html?id=g9781405131995_yr2013_chunk_g9 7814051319958_ss136-1>.
} 
usually means in the center of the page below the primary article; or an article on the periphery of the page) ; (8) whether the article is accompanied by a photograph, cartoon, information graphic (e.g. a poll, a graph or chart, or a brief mini-article relating to the main article), or some combination of these items; and (9) whether the article featured in a "teaser" on the front page.

The content of the article will then be assessed by a variety of means. In order to do this, I will use a modified version of a qualitative analysis similar to the grounded theory proposed by Anselm Strauss. By that, I mean that I will conduct a short analysis of each article and identify the key areas of interest for my study and go through the process of developing a coding structure along the way according to the open coding method proposed by Strauss. ${ }^{167}$ I have adopted this open coding structure because of the unknown aspect of the specific content that is contained within the RBTH supplements. Before my research began, the topics that RBTH would discuss were largely unknown in the beginning of the research, thus the coding needed to be able to grow and expand as a result of the changing nature of the RBTH supplements.

The coding structure for this falls into the following general categories: (10) geographical framing of the article (described further in the following chapter); (11) the specific topic addressed in the article (described further in the following chapter); (12) the primary framing of the article [what is the general focus of the article in relatively broad categories]

\footnotetext{
167 Bertram Scheufele, "Grounded Theory," The International Encyclopedia of Communication, Blackwell Reference Online (Blackwell Publishing, n.d.), http://www.communicationencyclopedia.com/subscriber/tocnode.html?id=g9781405131995_yr2013_chunk_g97 814051319958_ss136-1.
} 
(described further in the following chapter); (13) I determined the general approach of the author to the primary framing of the article as determined in (12) as being positive, critical \{negative\}, or neutral; the next step was then to analyze what the author was either positive or negative about [for neutral no further determination was made], if the article was deemed positive in (13) then, it would be coded in category (14); if the article was deemed critical \{negative in (13) then, it would be coded in category (15); (16-18) follows the same criteria as (13-15) except with relation to a secondary framing topic if there was a topic that warranted its own individual assessment [i.e. having considerable influence on the meaning and purpose of the article that is separate from the primary meaning] (19-21) follows the same pattern as the (13-15) and (16-18) except with relation to a tertiary framing topic [again only if necessary and substantially different from both the primary and secondary framing]. In the final step (22), I determined the strategic framing of the article based off of my own assessment of the tone and content of the article [more than one assessment in this category was possible]. These strategies will be discussed in greater detail in the Results and Analysis chapter.

During the open coding process, I routinely corrected, added, merged ideas, renamed codes, and modified the coding structure in accordance with Strauss's theory of open coding. ${ }^{168}$ In addition, after all the coding was done, I performed one final consolidation effort in order to clarify my findings and make them more digestible. After the process of coding was complete, I was able to run a comprehensive content analysis of the data that I had coded.

I used the online content analysis software "Dedoose" to perform the coding as well as the analysis, which was supplemented by the use of Microsoft Excel.

\footnotetext{
168 Ibid.
} 


\subsection{Limitations of the Research Design}

As with any methodology, there are of course limitations. Klaus Krippendorff identifies two general limitations with the idea of content analysis. First, a problem arise with the fact that a content analysis requires a large data set in order to be viable. ${ }^{169}$ In the case of my research design, I have a substantial data set of nearly 450 pieces of data that allows me to make certain judgments and conclusions on trends. Second, Krippendorff states that the replicability of the content analysis can be a cause for concern. ${ }^{170}$ This is of course a concern with any content analysis and mine is no exception. Although content analyses claim to be objective, they are subjective in many ways. Regarding my particular research design, the decision-making process involved in the open coding process is the result of my own interpretations of the articles. However, this is unavoidable, as I am an intrinsically involved in the entire process. There are some aspects like the date, location, author, etc., however, that are indisputable and allow for the maintenance of a certain level of objectivity.

These criticisms of the process are not unique to content analysis, open coding or qualitative analysis. All research involves at least some level of the researcher being involved in making decisions that could possibly alter the eventual findings of the study. At least with content analysis, there is a credible attempt at limiting the levels of subjectivity involved in the research process. I would argue that the systematic nature of my methodology gives an added sense of credibility to the process. While some subjectivity is inevitable, I argue that the

\footnotetext{
${ }^{169}$ Klaus Krippendorff, “Content Analysis,” International Encyclopedia of Communication, January 1, $1989,407$. 170 Ibid.
} 
combined nature of my approach allows for this subjectivity to be discounted in terms of the qualitative aspects, due to the fact that they will also face the structure of a content analysis as described above.

\subsection{Source of the Data}

As discussed thoroughly above, RBTH is a clear attempt at soft power/public diplomacy cultivation on the part of the Russian Federation. Its nature has also been thoroughly discussed. There are very few academic studies about RBTH, and none that examine its publishing activity during the Ukrainian crisis of 2014.

This study is limited to the inserts that were published in the print editions of the Washington Post (WP), the New York Times (NYT) and the Wall Street Journal (WSJ) during the calendar year of 2014. The reasoning behind this decision has been discussed above in the Empirical Background chapter. These supplements are supposed to be published on a regular, monthly schedule, however, for reasons unknown, they have appeared irregularly. During 2014, 18 supplements were published in these three newspapers, 6 in NYT, 7 in WP and 5 in WSJ. No supplements were published in January, July or August in any of the supplements. Every other month had at least one supplement published in an American newspaper. See the Appendix A for a full list.

Every article published in each supplement is included in this assessment, including stand-alone information graphics or other pieces of a miscellaneous nature. The length of the 
RBTH supplement for NYT and WSJ are 8 pages long, while WP supplements are only 6 pages long. As stated above in the Empirical Background chapter, the layout and style of each edition is associated with the layout and style of the partner newspaper. 


\section{Results and Analysis}

\subsection{Results}

\section{General Data}

To begin, I will provide an overview of the general data on the articles analyzed. The total number of pieces of data came to 449. The breakdown of these by category is as follows.

\section{(2) Genre}

\section{NUMBER OF APPEARANCES BY TYPE}

-General Article $\square$ Interview $\square$ Opinion $\square$ News Brief $\square$ Other $\square$ Standalone Info Graphics $\square$ Book Review

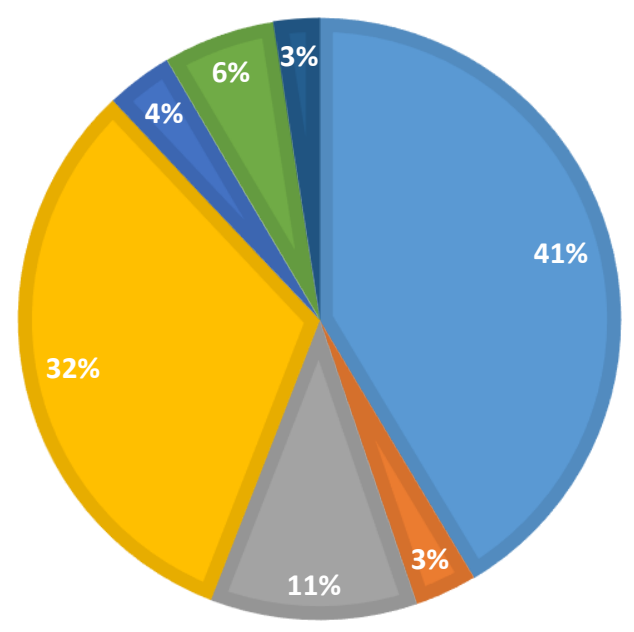

Each of these categories breaks down in this manner: a "general article" is any standard journalistic article of substantive size; an "interview" is simply an interview that is reported in a question and answer format; an "opinion" article is any article that is marked as an "opinion", "viewpoint" or other signifier, and/or that expresses the private views of an individual; a "news brief" is any short article that provides only a headline or short text on a specific subject, and typically labeled with the headline "news brief" or "news in brief" but also short blurbs about 
cultural events can also fit into this category; a "stand-alone information graphic" is an item that is not directly attached to a larger article such as a poll, the "RBTH for Kids" section of the NYT, a "headline quote" in WSJ, a travel advertisement in the form of an information graphic, or a mini article; a "book review" is quite simply a book review; the "other" definition relates to a variety of pieces that are either of insignificant number or of an insignificant content nature, which included cooking articles, letters to the editor, letters from the editor, or short teasers for online materials.

\section{(3) Publication Accompanied}

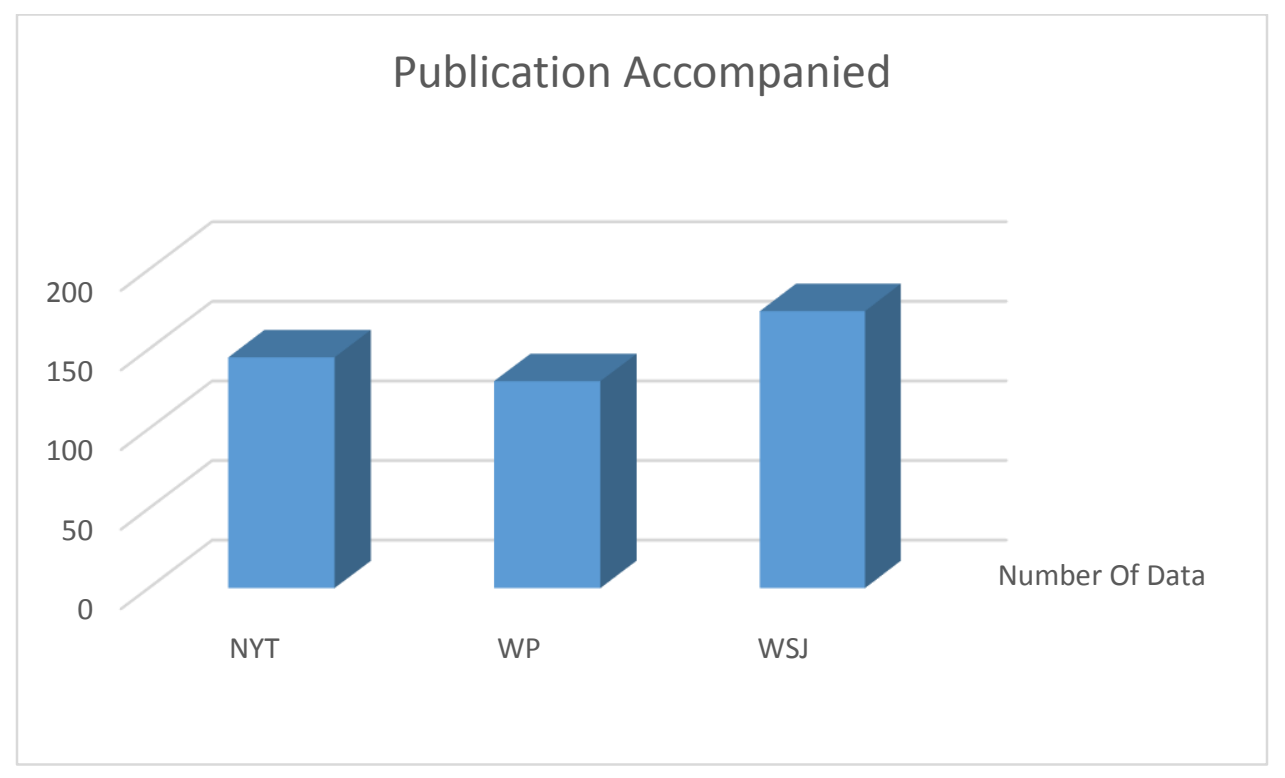

\section{(4) Authorship}

The overwhelming majority of articles were written by RBTH journalists or freelance journalists hired by RBTH, as its website claimed. The importance and nature of the other authors will be made more clear in a later section about the results of this research. 


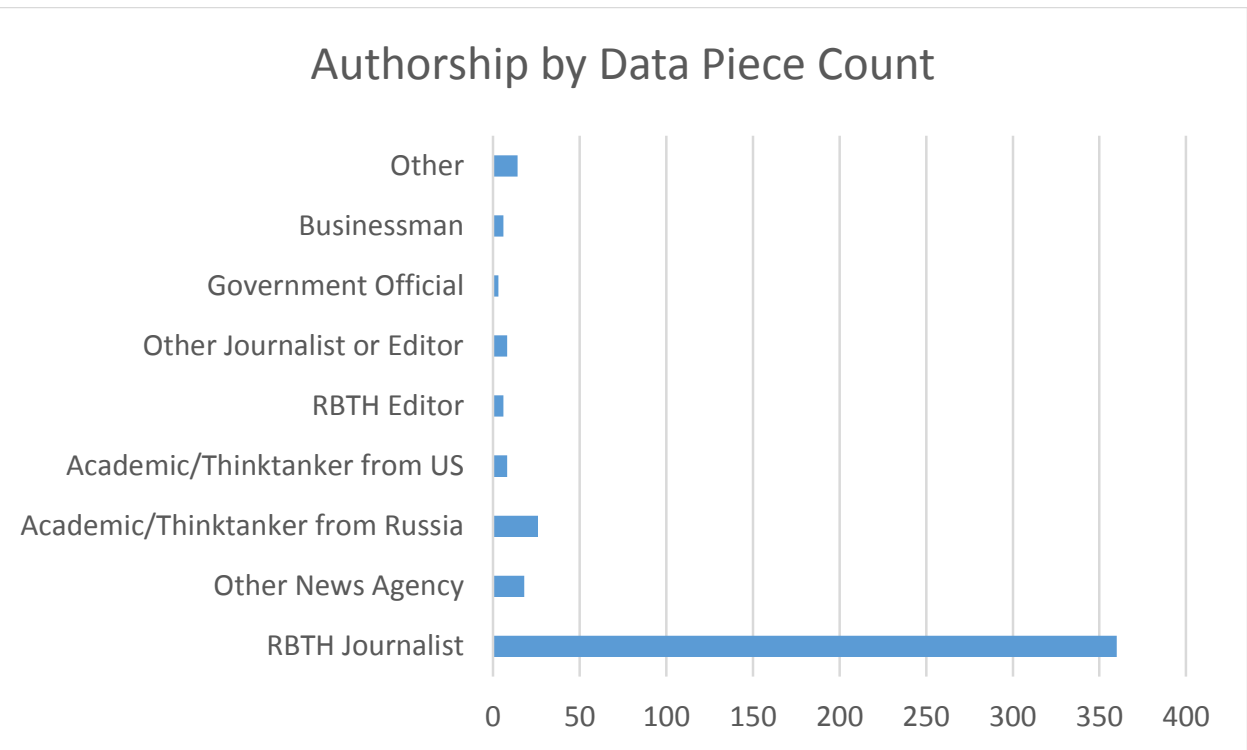

\section{(5) Length of Article}

\section{LENGTH OF DATA}

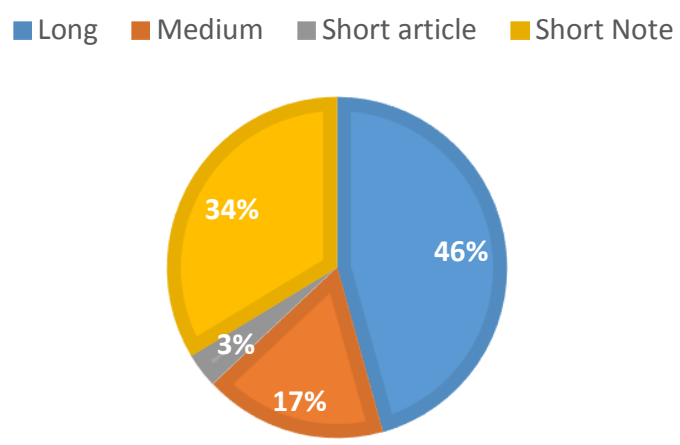

A long article consisted of over 500 words; a medium article had between 300 and 499 words; a short article consisted of between 100 and 299 words, and a short note was 99 words or less (typically a news brief or info graphic).

Framing of Articles

\section{(10) Geographic Framing of Articles}

The overwhelming majority of articles involve a geographical framing that is either in Russia or involves an issue between Russia and the United States. 


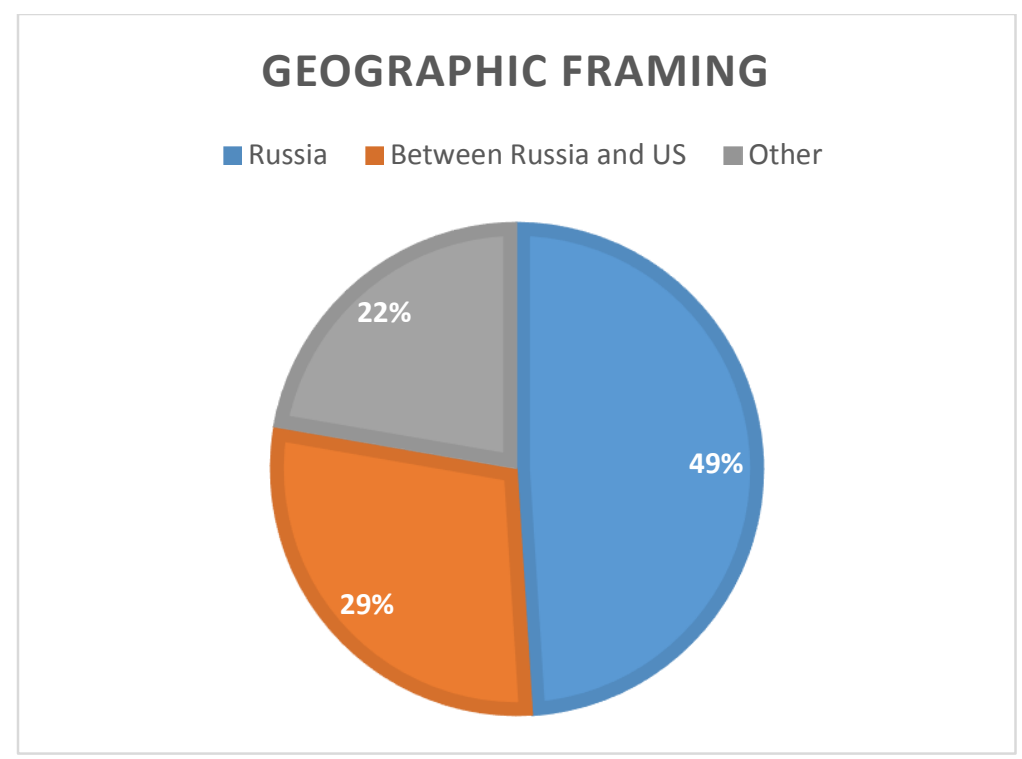

For the other categories of geographic framing, there were exactly 100 pieces of data. The break down for this group is as follows:

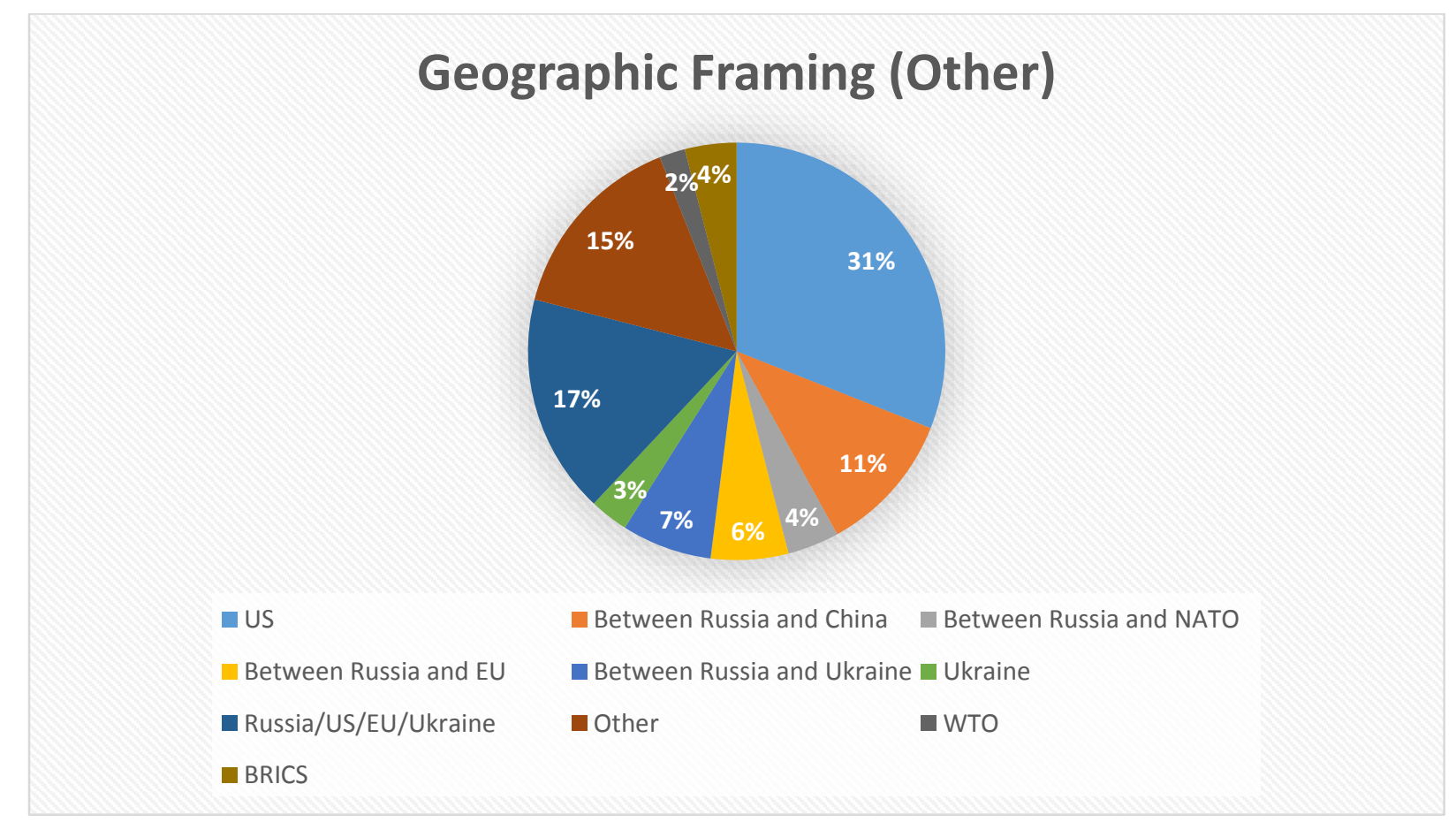

As is clear from the data, RBTH is focused primarily on what is happening in Russia (49\% of total) and what is happening between Russia and the US ( $29 \%$ of total). The "other" category has a large chunk devoted to the US, but this framing is a distance third compared to the two 
main categories (just 7\%). At just $7 \%$ of total data pieces, the Ukrainian crisis is also given only a cursory look, and even that is primarily dedicated to the geopolitical situation involving multiple actors, which accounts for about $5 \%$ of the grand total leaving actual only $2 \%$ for Ukraine itself.

As a result of these findings, I will provide a brief analysis of the two main framings ("In Russia" and "between Russia and the United States"). The geographic framing of each article also provides us with a variety of other data points to compare with the framing of content and with that of the strategies and tactics.

The general layout for the "in Russia" data pieces was as follows:

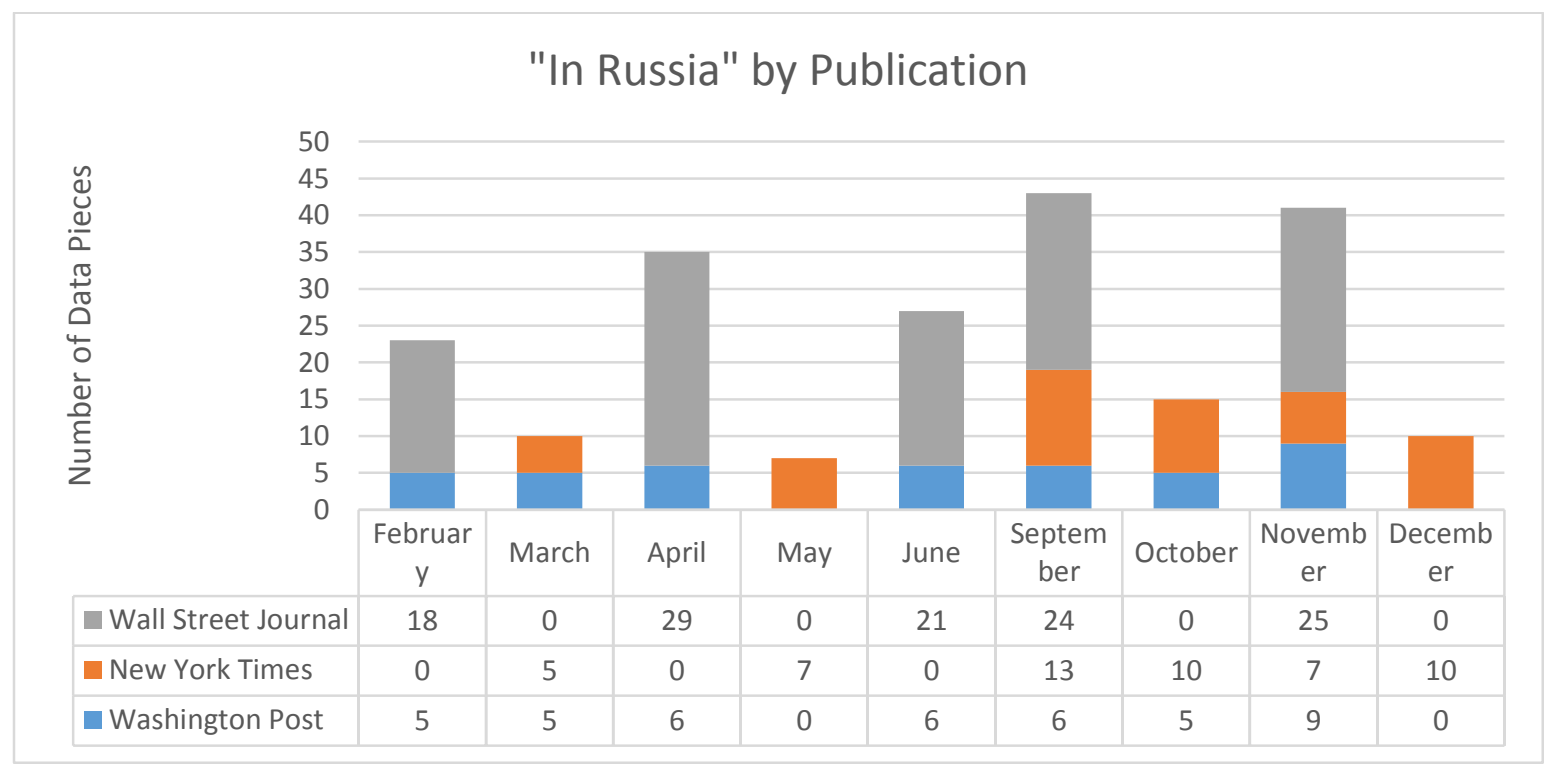




\section{STYLE OF "IN RUSSIA" (PRIMARY FRAMING)}

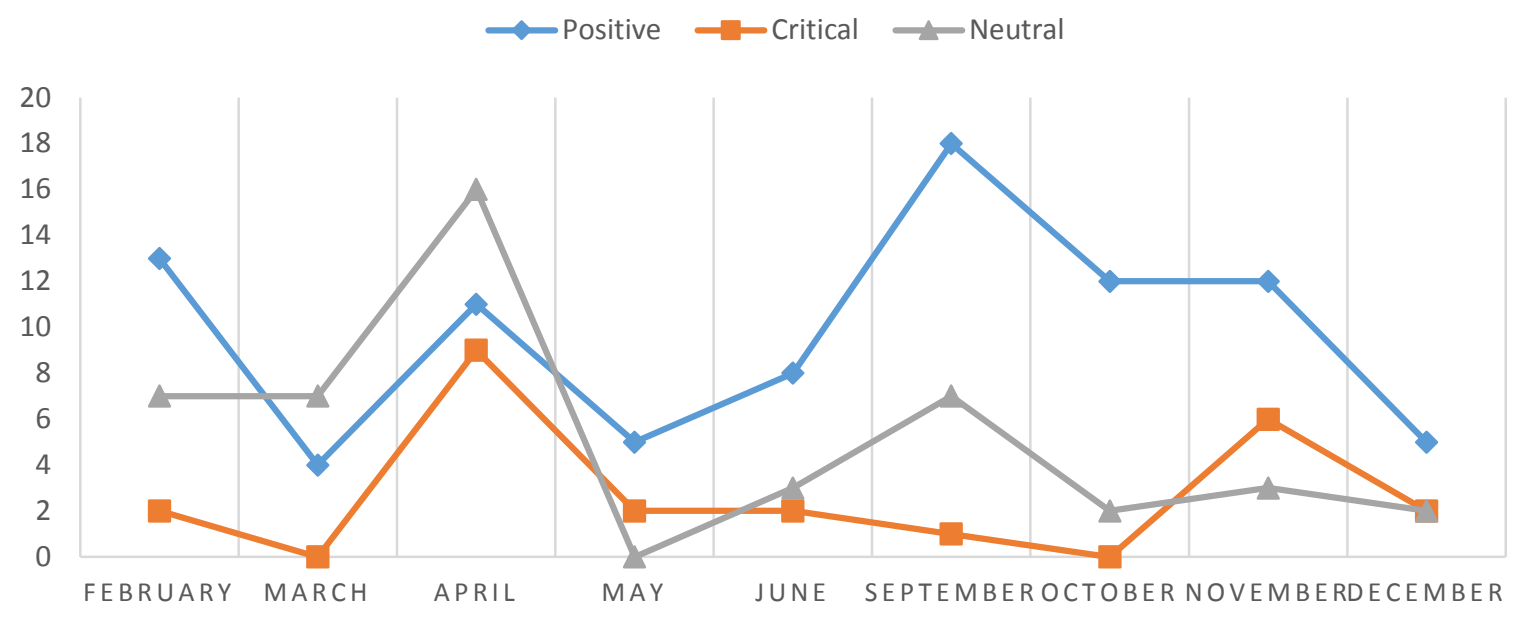

For the "between Russia and the United States" data pieces the general layout was:

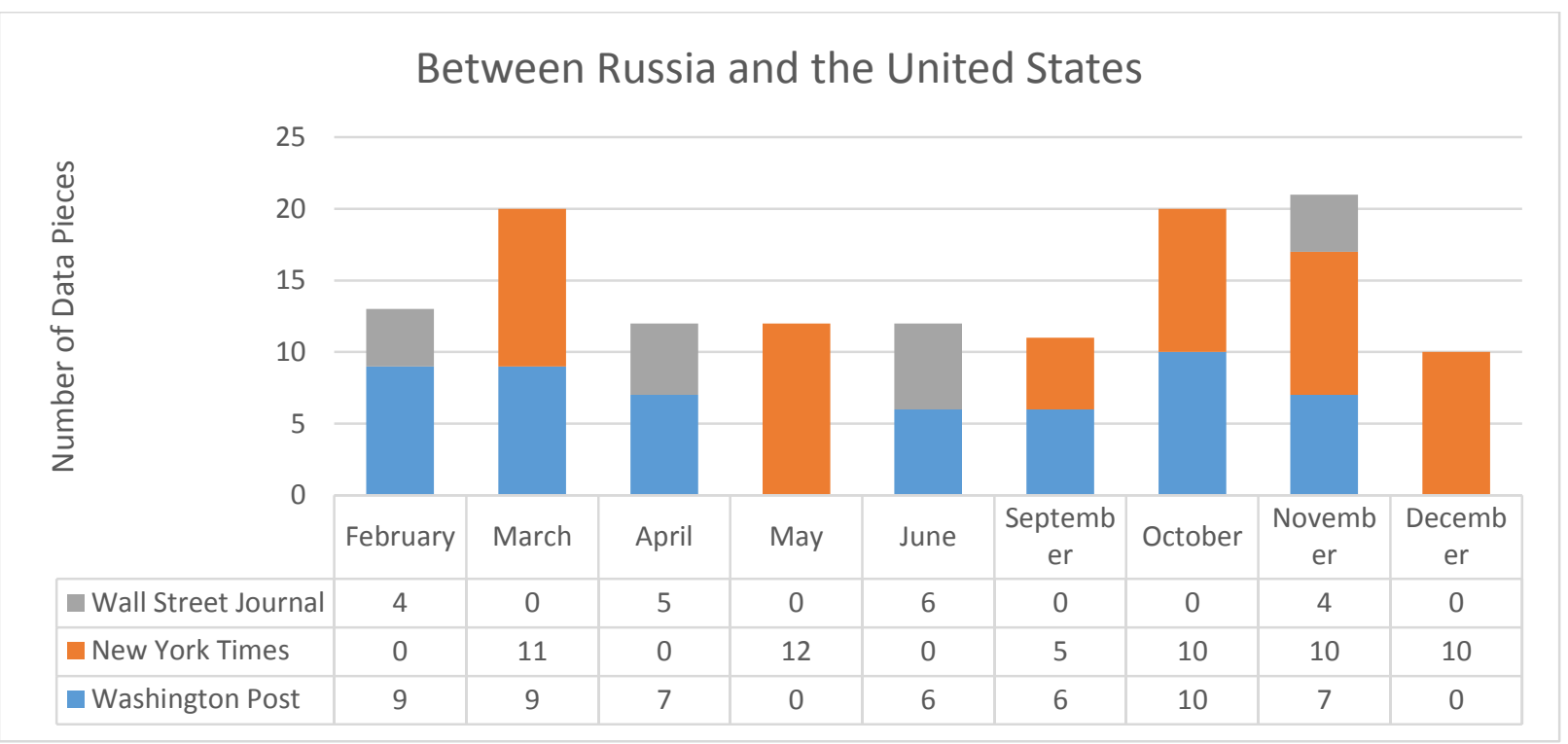




\section{STYLE OF "BETWEEN RUSSIA AND US" (PRIMARY FRAMING)}

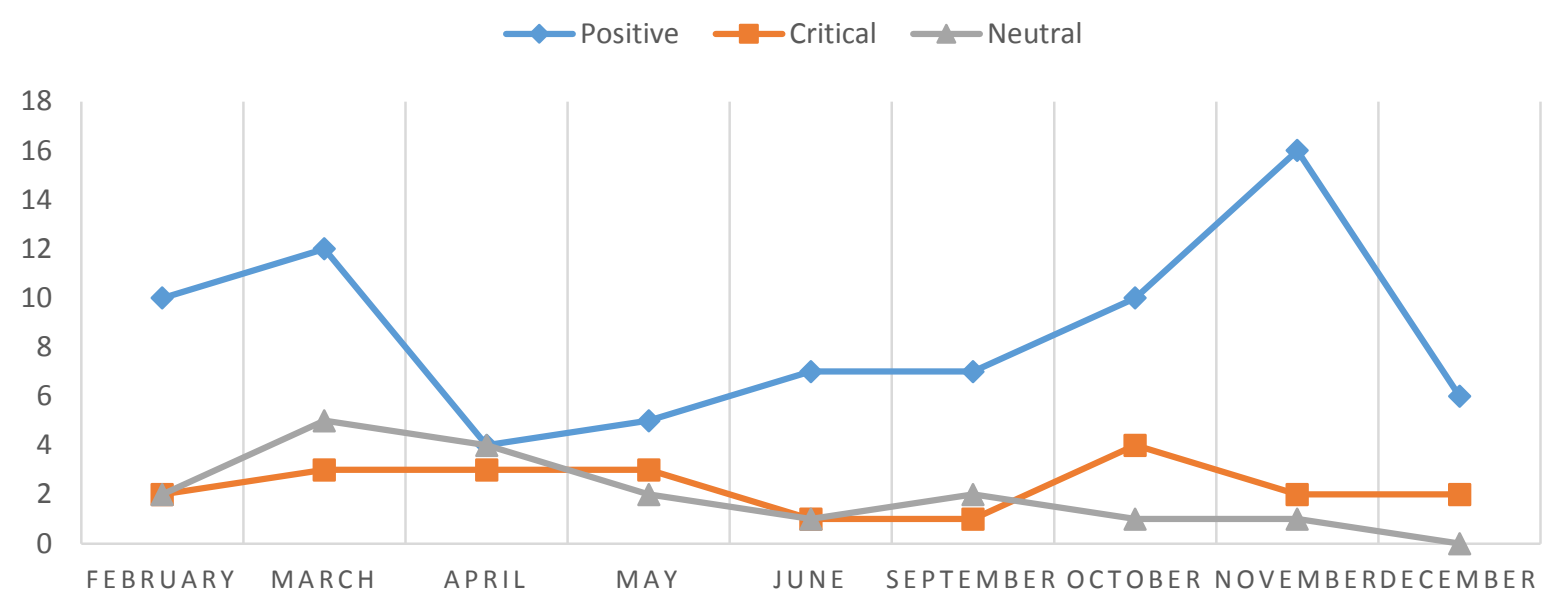

As we can see from both charts provided (as well as the data from the other geographical framing codes), the level of consistency between them shows that NYT and WP are focused more on the "between Russia and the US" mindset, while WSJ is focused more directly on what is happening in Russia. It is important to remember that for certain months a supplement was not published by its respective newspaper, so that can account for the falls to 0 in most cases in these charts now and perhaps in the future as well, when seen over the course of time with a large enough dataset.

\section{(12) Primary content}

The total number of data relating to the main primary coding categories are: 


\section{Primary Framing by Category}

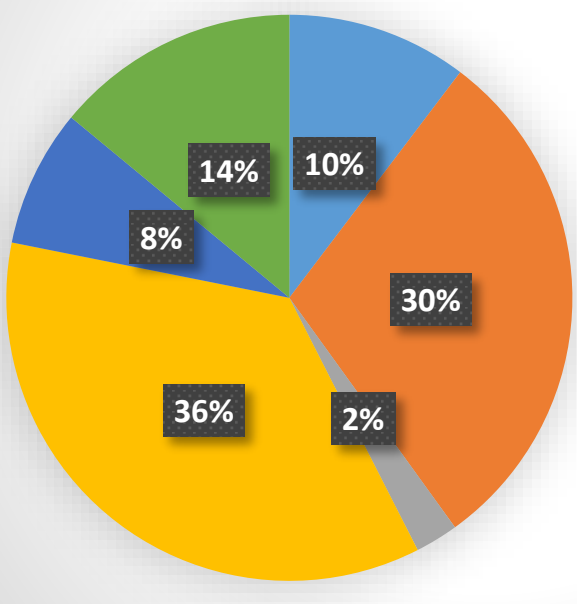

Politics

- Culture

History

Economics

- Ukrainian Crisis/Sanction

Other

Economics and culture dominate the primary framing of articles. This makes sense for two main reasons. First, Russia has a strong cultural past that is attractive to the American public. Second, WSJ is a business newspaper, and the supplement for NYT is designated as a part of the business section, although the NYT may not account for nearly as much of the economicsfocused items as the WSJ, as we see with the chart below:

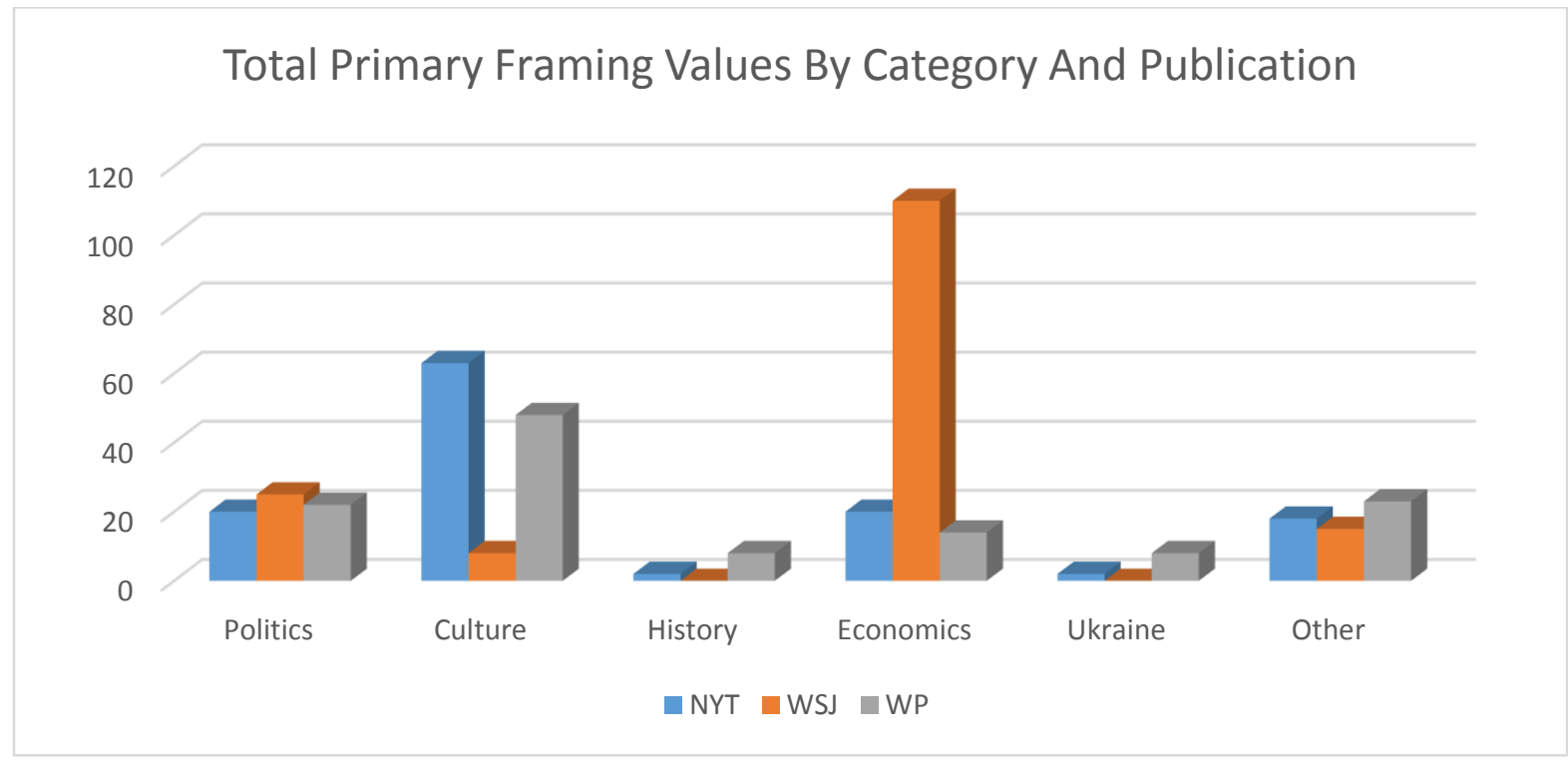


With this chart we see that news about economics is by far and away the most important thing to WSJ. However, some of this can be accounted for due to the large number of "News Briefs" that are short articles. There are many more of these "News Briefs" in the WSJ (between 1520) as opposed to NYT or WP which both have about 2-4 in each edition. As for the other two, they have a relatively similar mix of categories. To look more closely at this, here is how each newspaper's primary content looks by category and date:

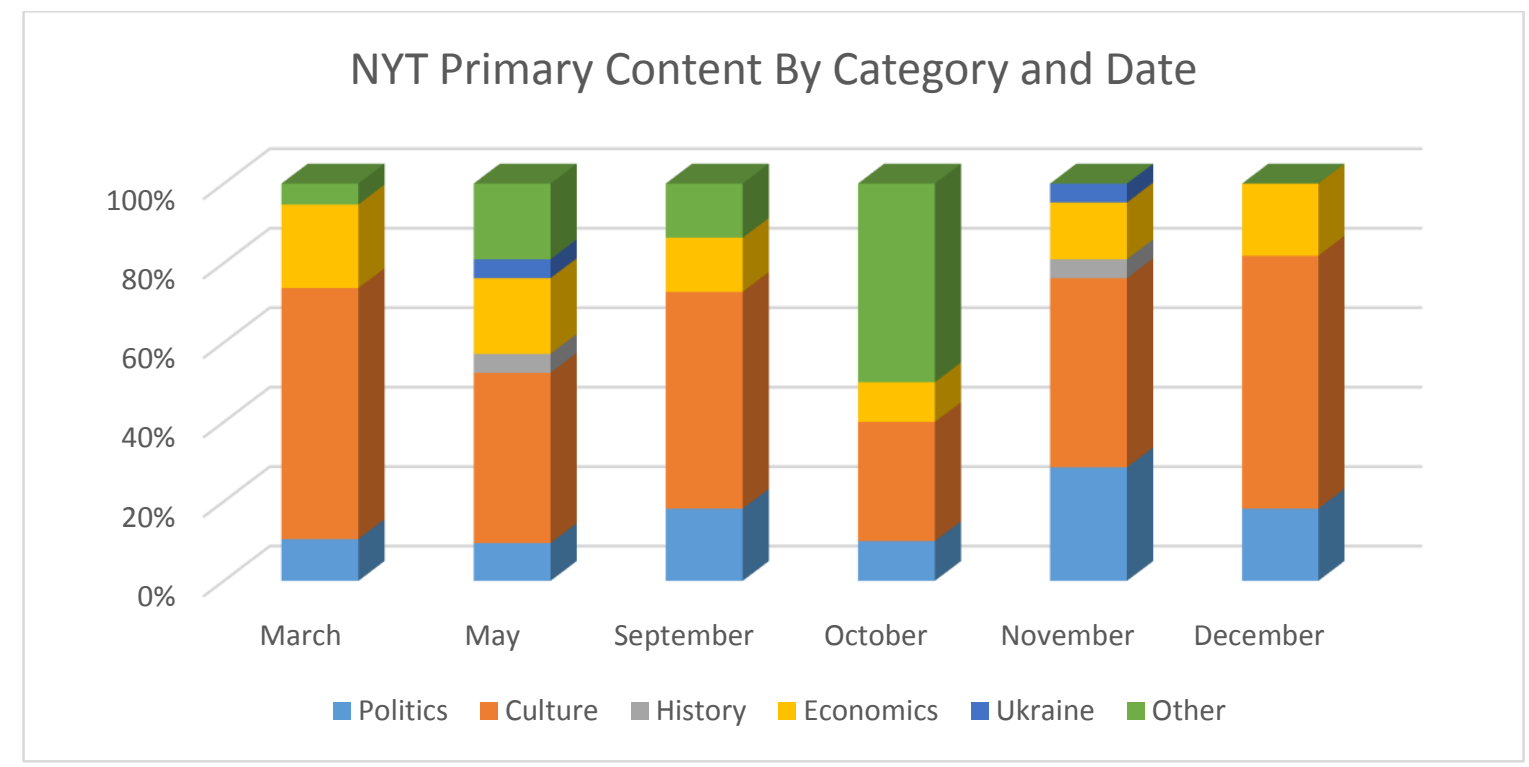

*NB the spike in "Other" articles in October is the result of a 2 page expose on the Russian space program. 


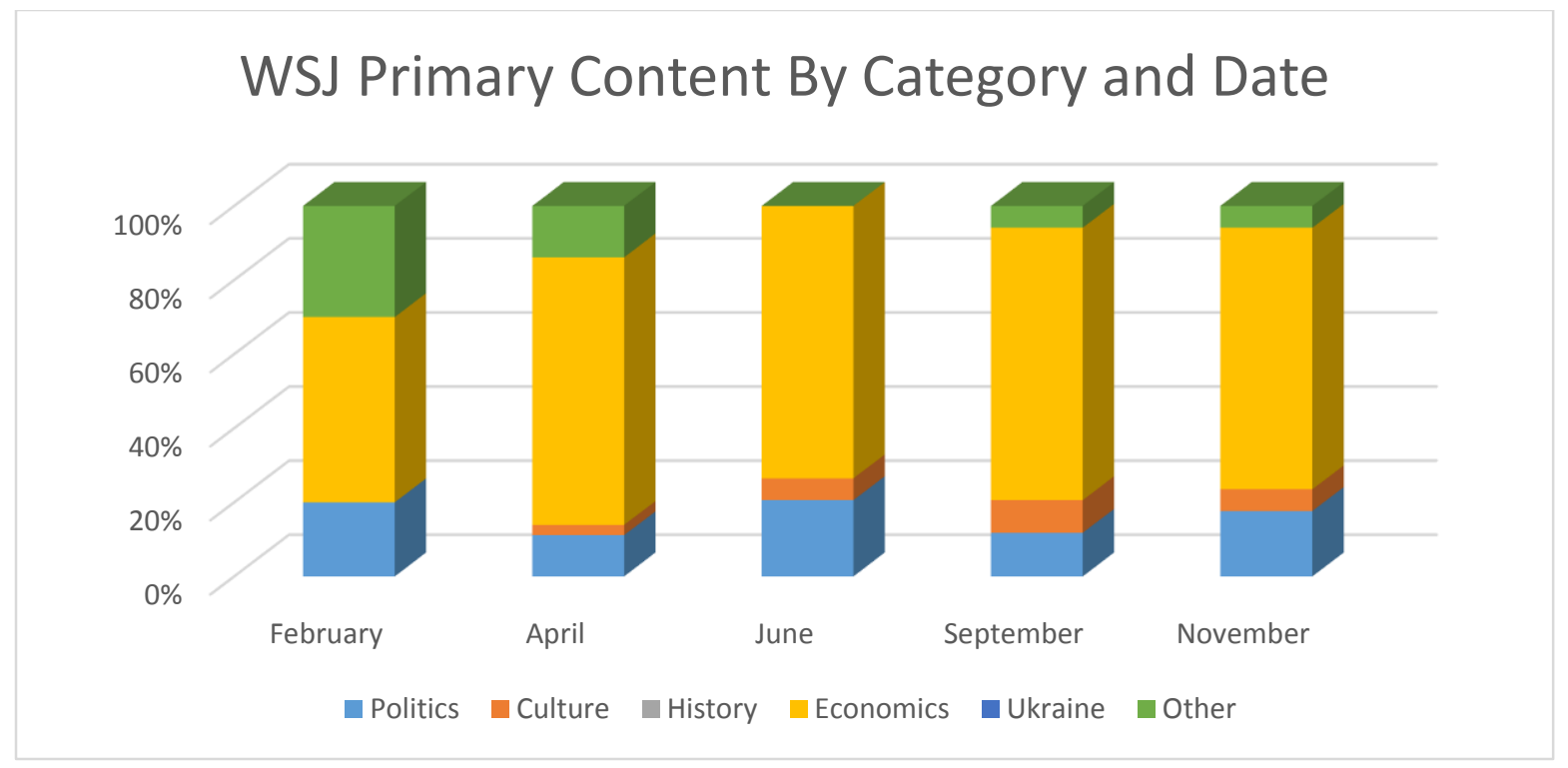

*NB The relative spike in "Other" in February and to a lesser extent April was Sochi coverage.

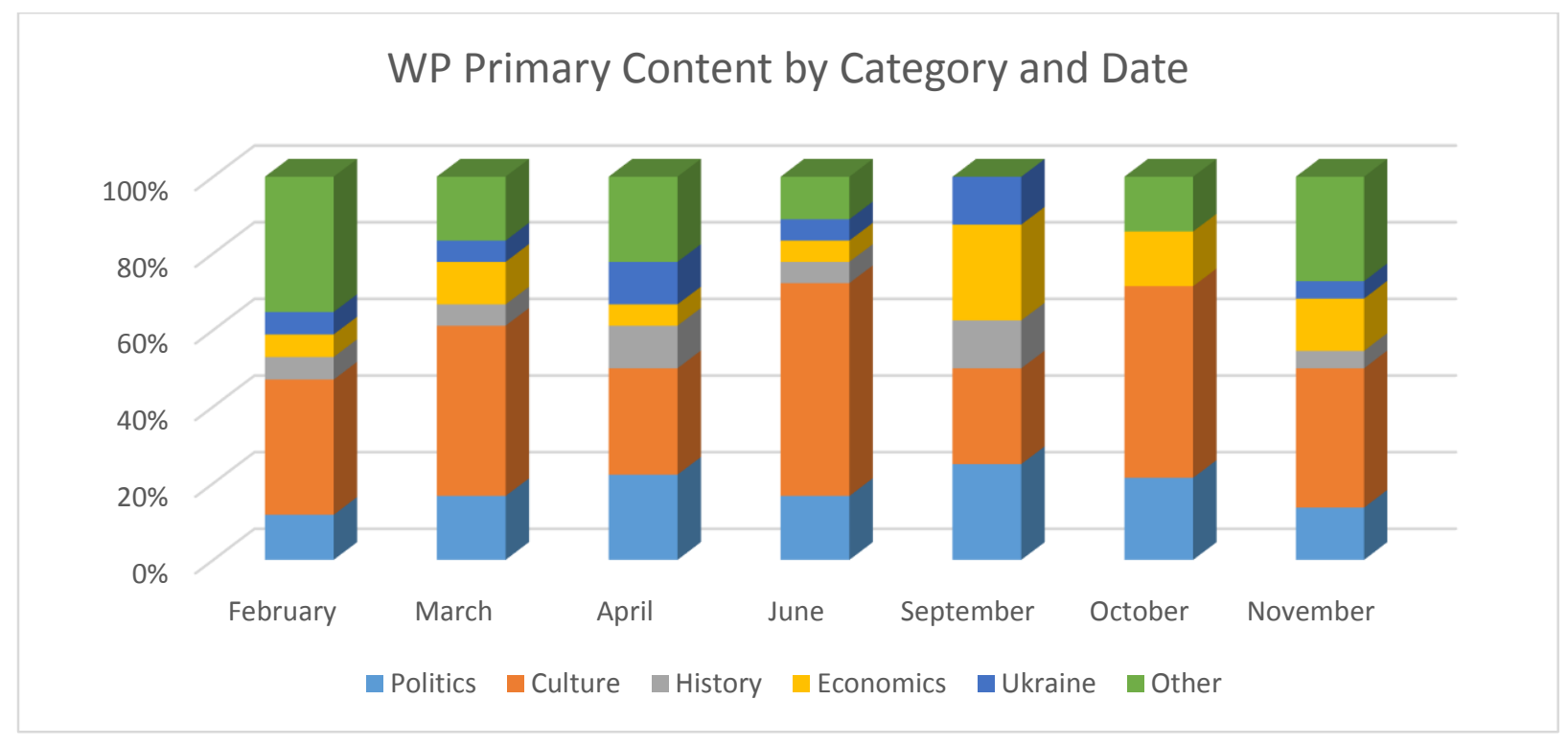

These charts show us that the primary content of articles is fairly constant in each edition. The supplements published in NYT are primarily targeted towards culture with politics and economics added to the mix. The WSJ supplements are primarily focused on economics, with a few political articles in each one, along with the occasional section on sports. The WP seems to be comprised of a fair mix of different articles from nearly every category. Culture is still 
primarily dominant, but politics and "other" have a fair showing, with economics being more prominent at different points. Notably, the WP discusses Ukraine as the primary framing reference the most out of the three papers, with 8 articles about it, while NYT had 2 and WSJ had 0.

Beyond the scope of the primary topic as a category, we have to look at how these topics were discussed. In this section, I will present data on how each category was discussed by each newspaper. However, for those areas that are underrepresented I will not provide a graph for that category (i.e. history and Ukraine).

\section{Politics}

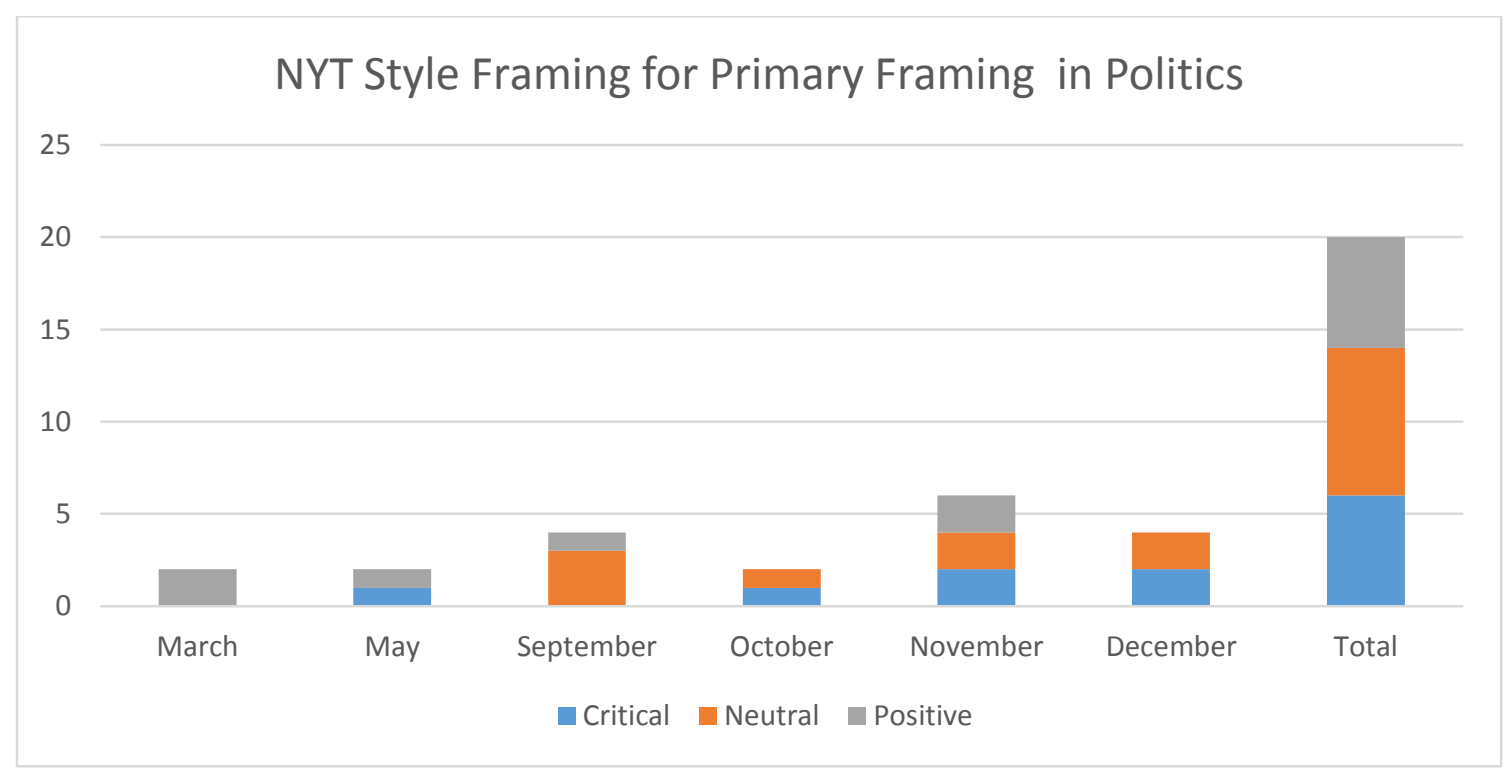



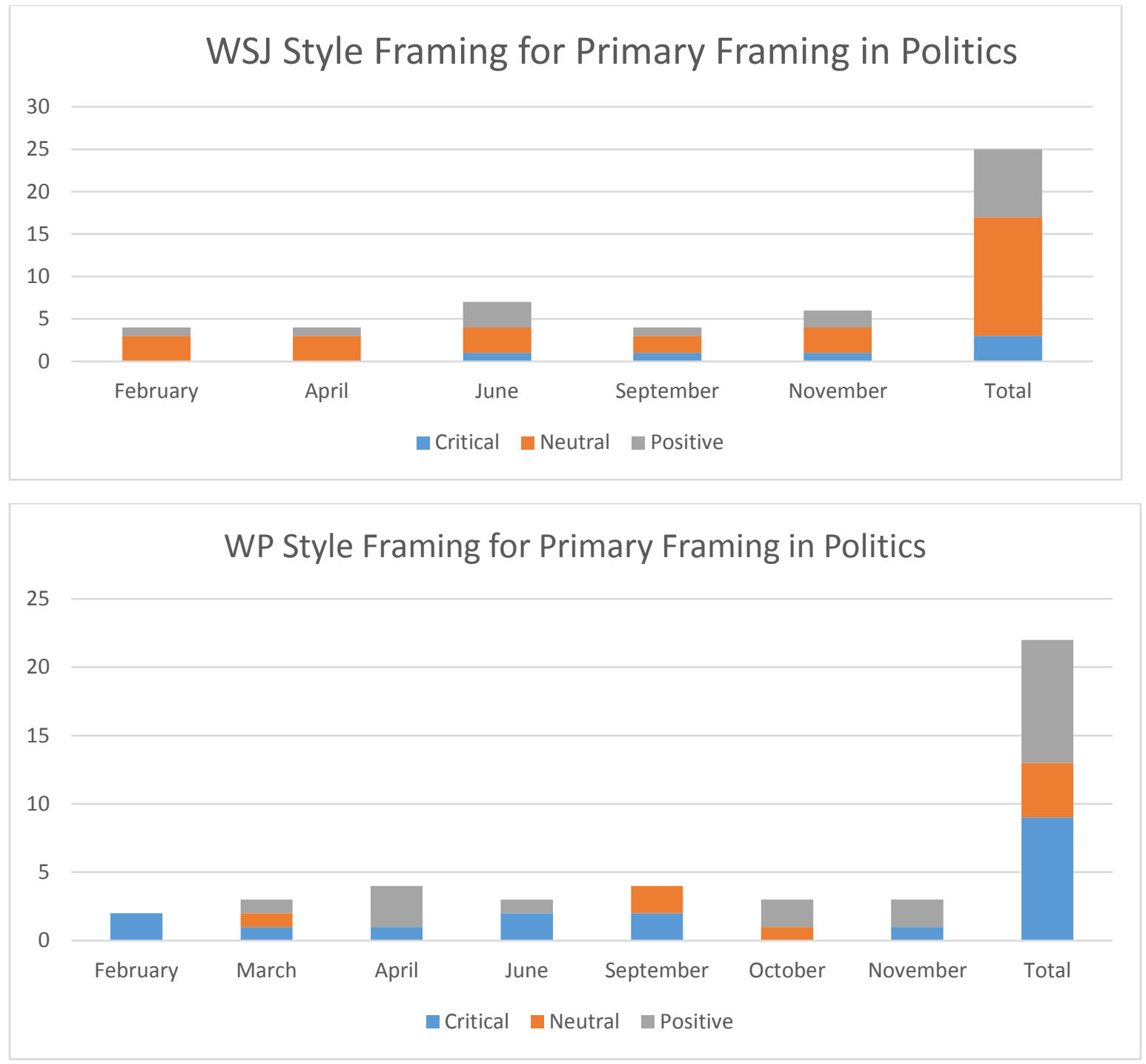

The primary style framing is slightly different for each section. All three have similar sample sizes. The NYT is fairly even across the spectrum and thus the editors of its RBHT supplement seem to wish to present a balanced political outlook. The WSJ has mainly neutral or possibly positive political views. Again this is consistent with a supplement that wants to engage its readers in a motto of "business not politics" (more to come below on this subject). The WP presents a different picture. Here the supplements take a position consistently and remain neutral on only a few topics. 


\section{Culture}
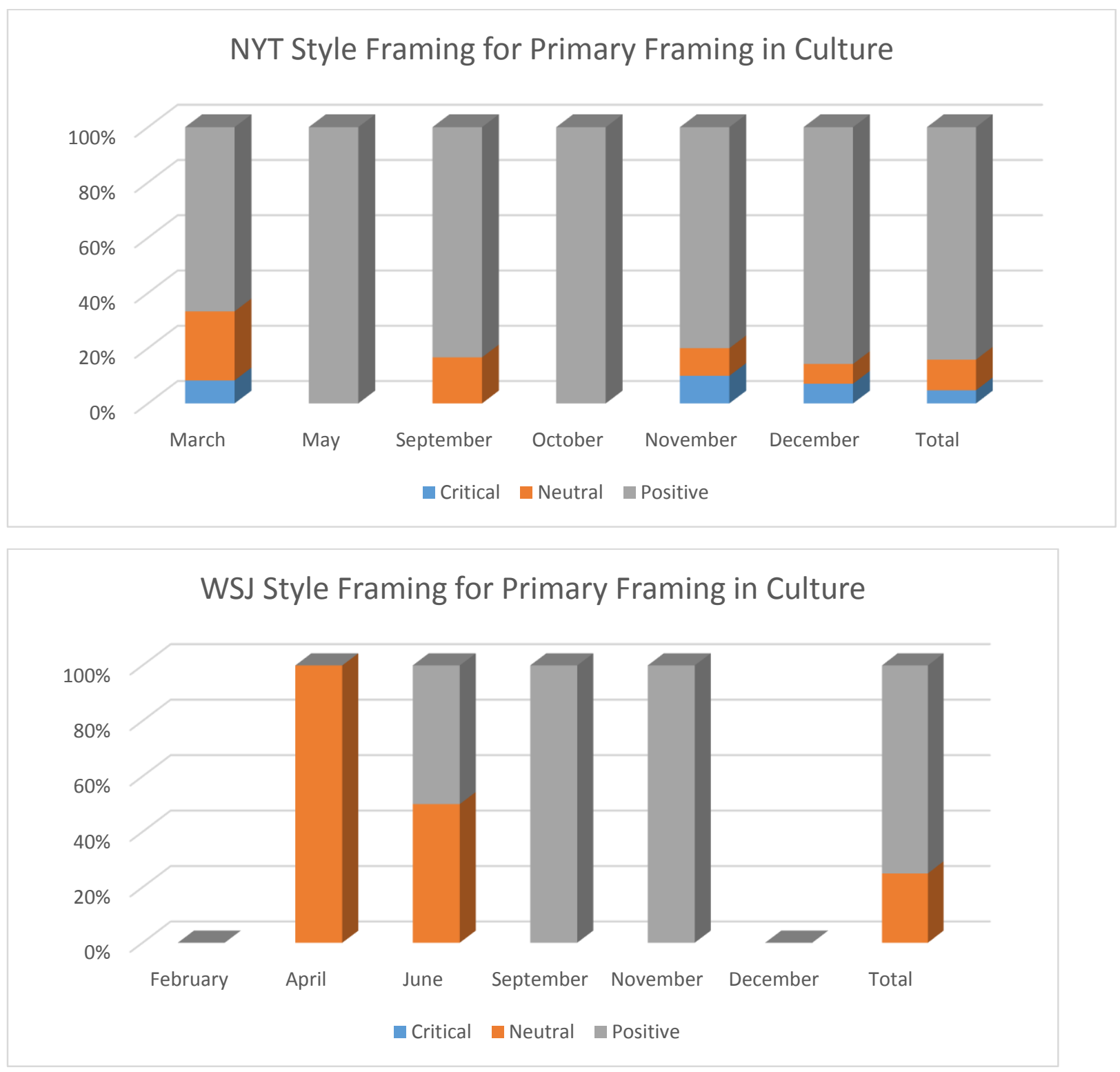


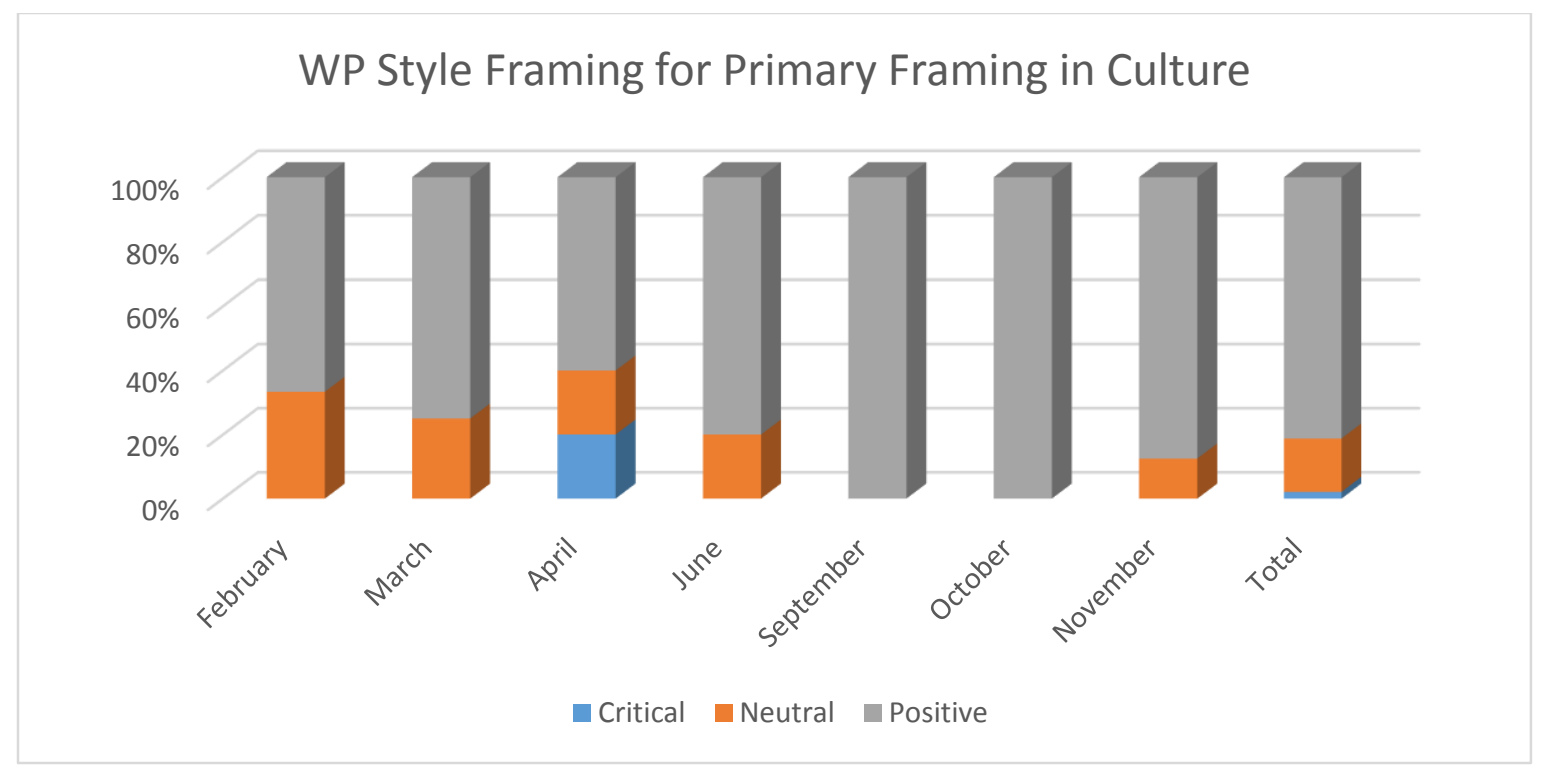

From these graphs, we see that for the most part each supplement is generally quite positive about culture. Both the NYT (63) and the WP (48) have relatively large sample sizes compared to WSJ (8). However, for all of them, the evidence is clear. Positivity about culture is good for soft power cultivation, which is fairly obvious. There is little backlash to praising either one's own or the other's culture (more below on this in the strategy section).

\section{Economics}

NYT Style Framing for Primary Framing in Economics

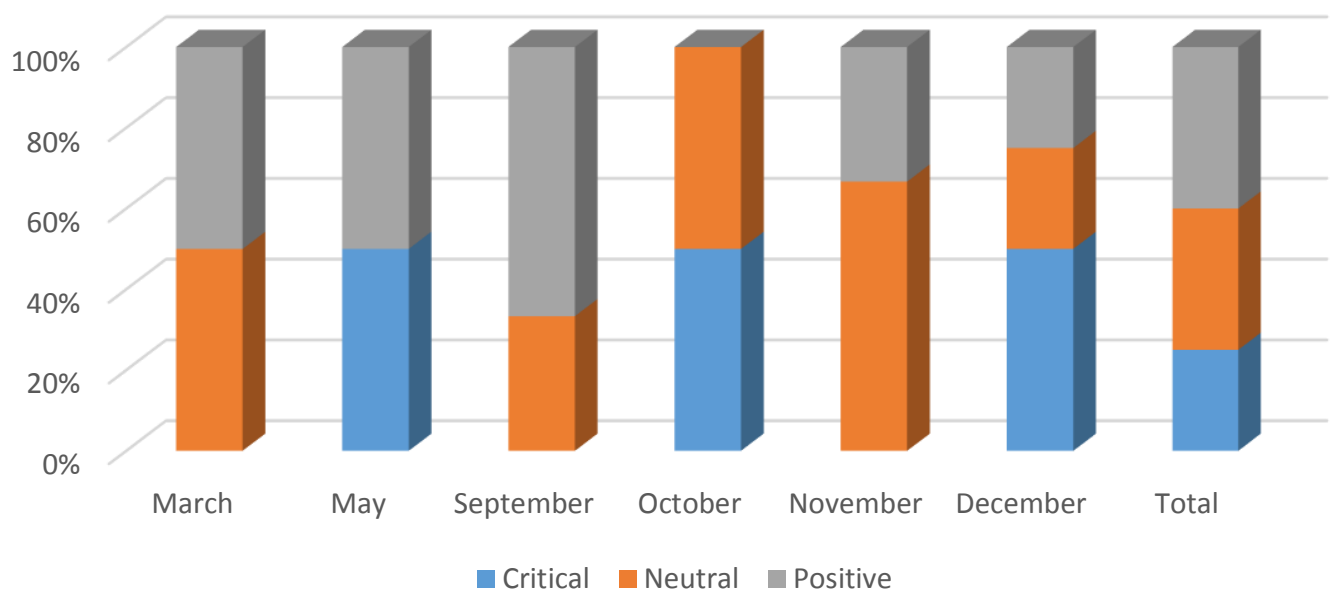




\section{WSJ Style Framing for Primary Framing in}

\section{Economics}

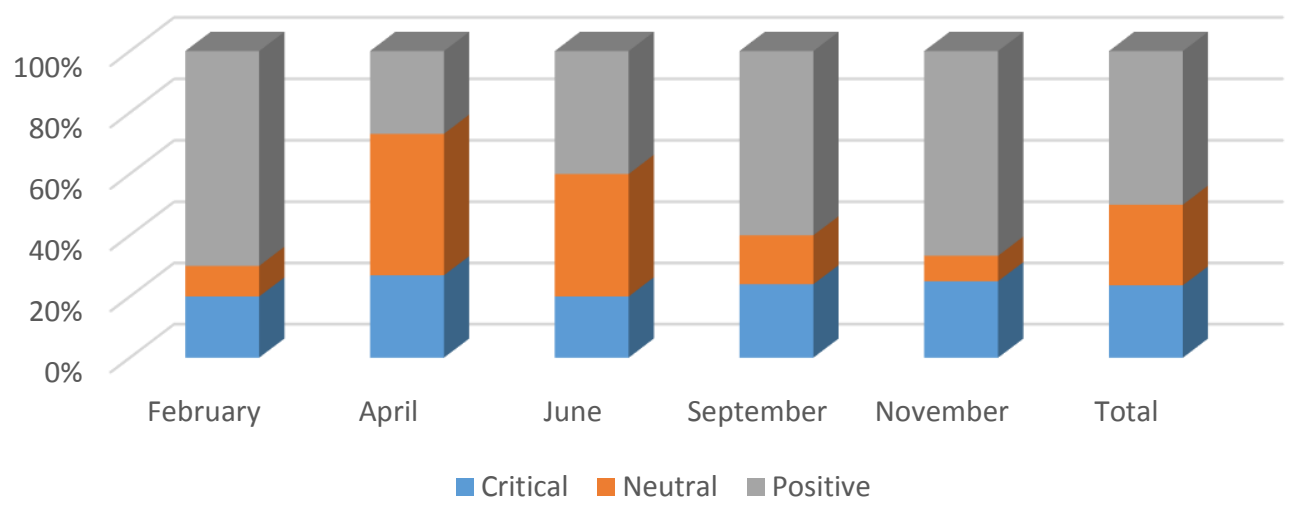

\section{WP Style Framing for Primary Framing in Economics}

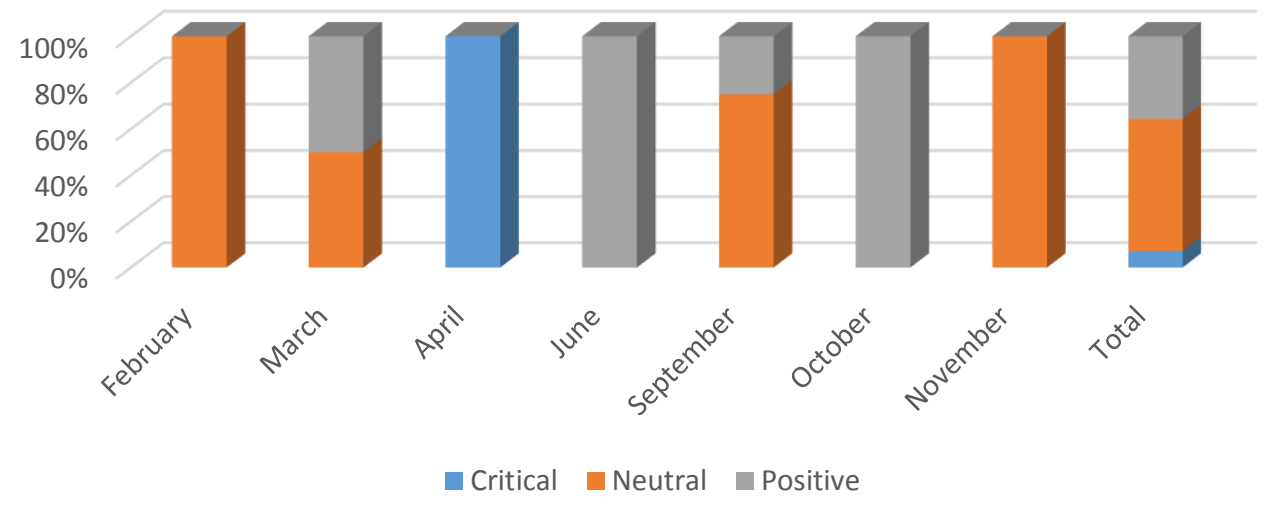

For economics, the data set situation is now reversed. WSJ had 110 items from the supplements devoted to economic news, while NYT had 20 and WP had 14. NYT had a mix of style framings from each category again. The WSJ had a clear majority that fluctuates between positive and neutral (55 and 29 respectively), yet there was a clear critical trend ( 26 total) that would suggest that the designers of the supplement wished to establish some credibility by including criticism of certain aspects of Russia's economy. WP has very few articles about 
economics but they are generally positive or neutral (April only had one economics article and it was also the WP supplement's only critical framing during the study).

\section{Other}

*NB "Other" includes pieces of data labeled sports, science and technology, education, and an original other category that featured everything else that didn't belong to one of the other categories.

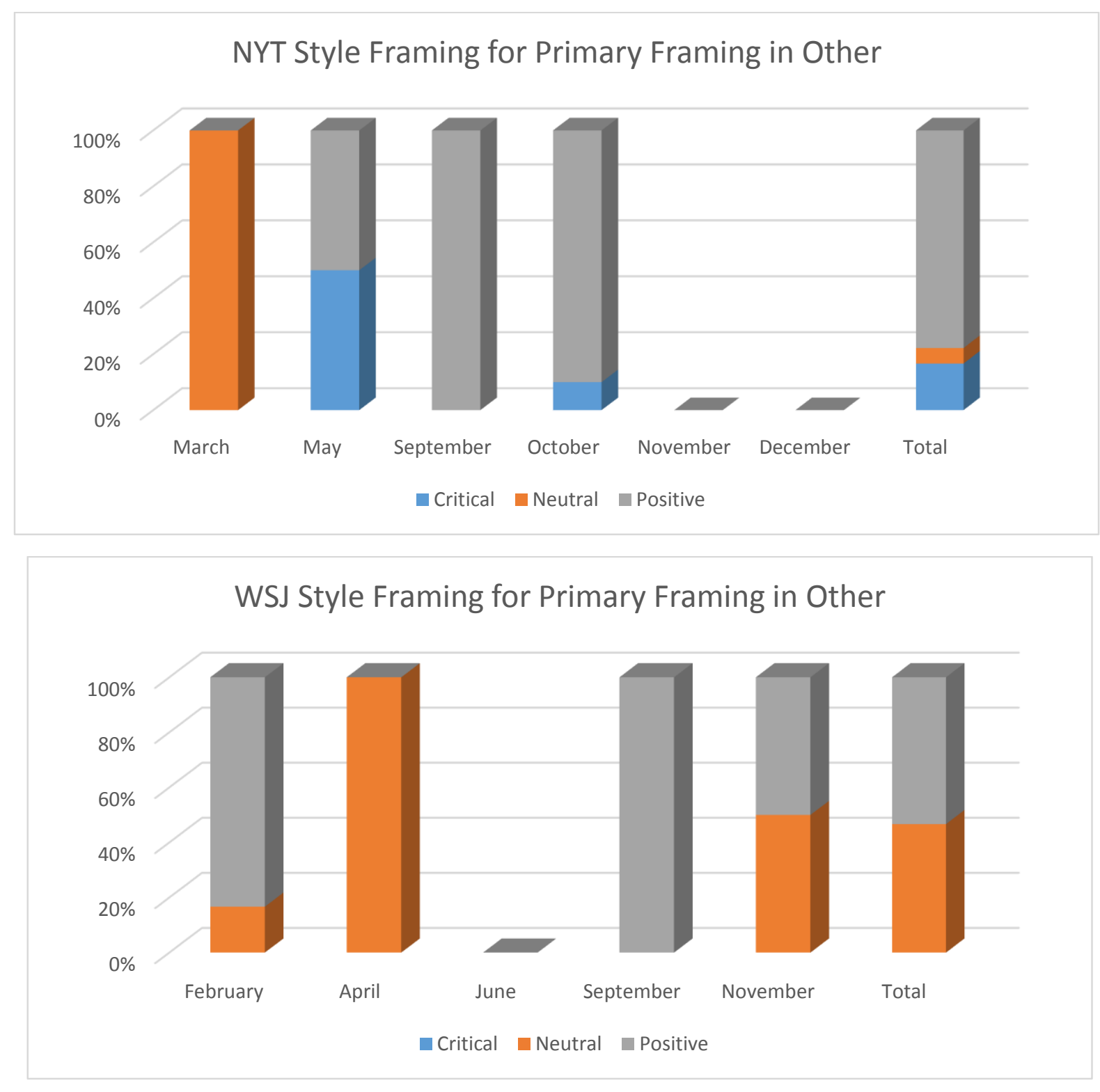




\section{WP Style Framing for Primary Framing in Other}

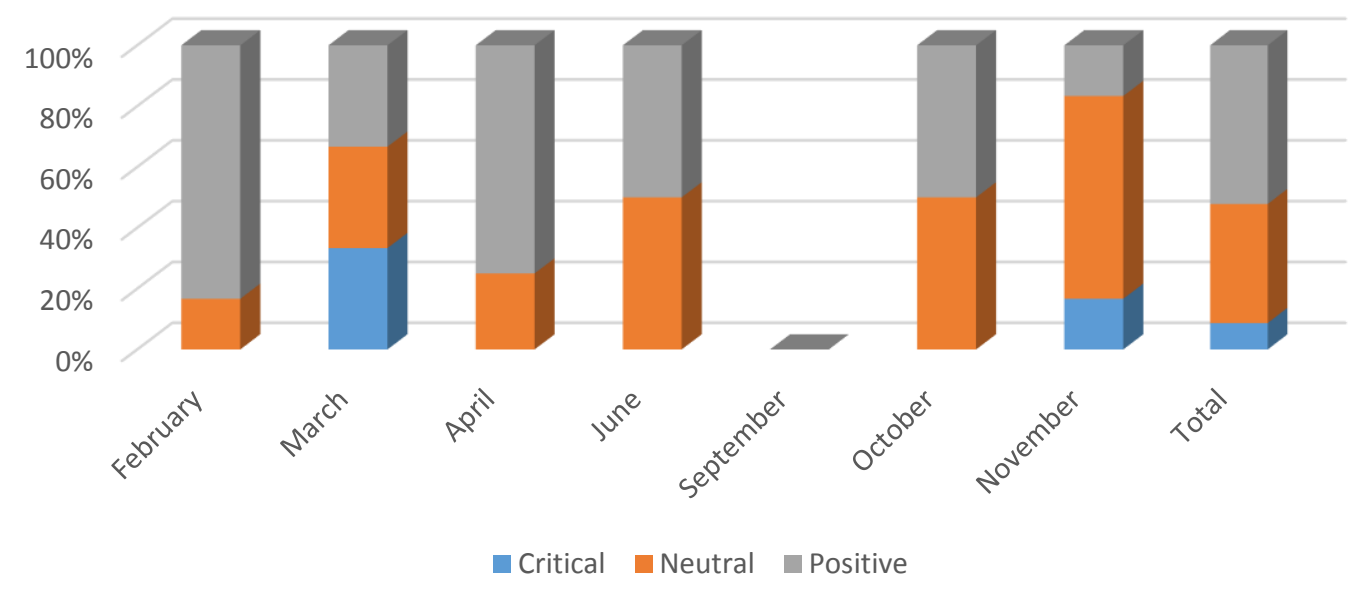

The sample size for these is again fairly small, but each one shows that positive messages are preferred in RBTH.

\section{Secondary Framing}

The data set is considerably smaller for the secondary framing (120) to that of the primary framing (407). The general makeup of this group is as follows:

\section{Secondary Framing by Categories}
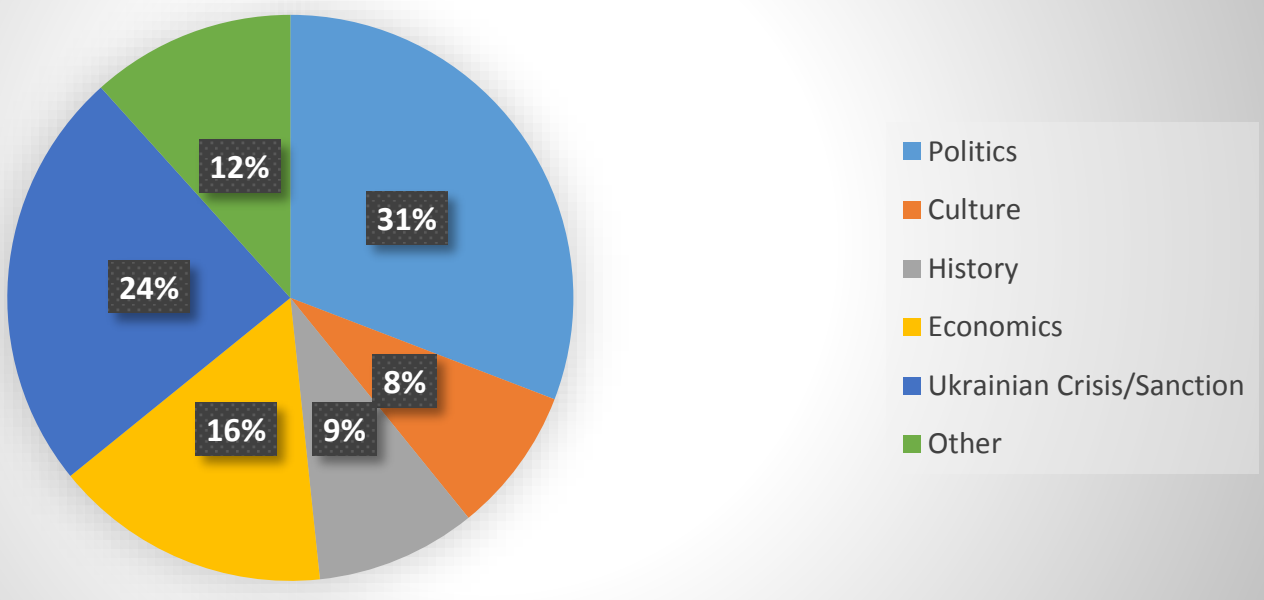
As this chart shows the break up is fairly even among the categories, with politics and Ukraine ranking the highest. However, the low number of data piece makes it undesirable to expand and analyze the data in as much detail as before. Instead, I will present a general overview of the style of the articles in each publication as a whole, instead of in a month by month fashion.

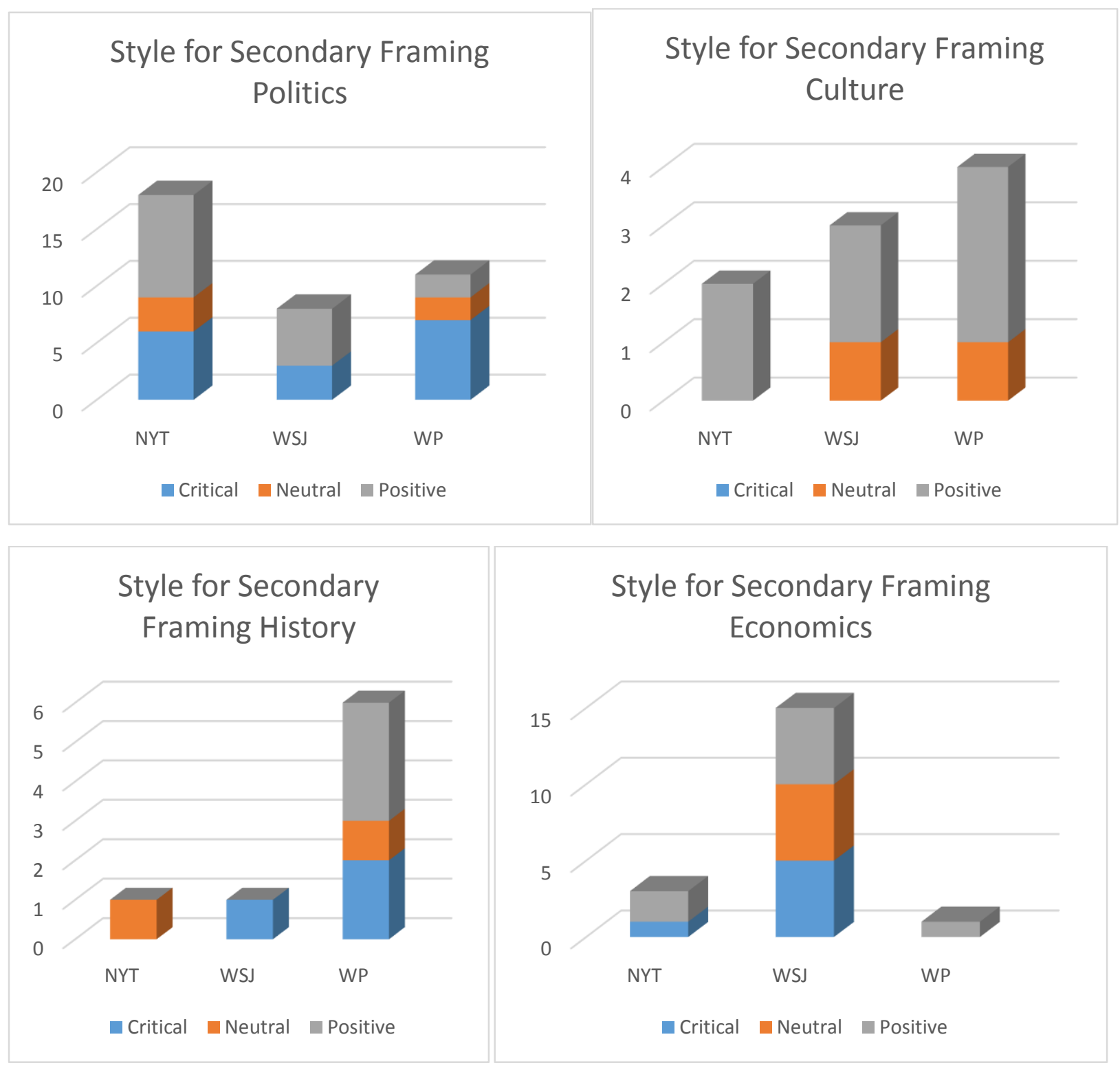



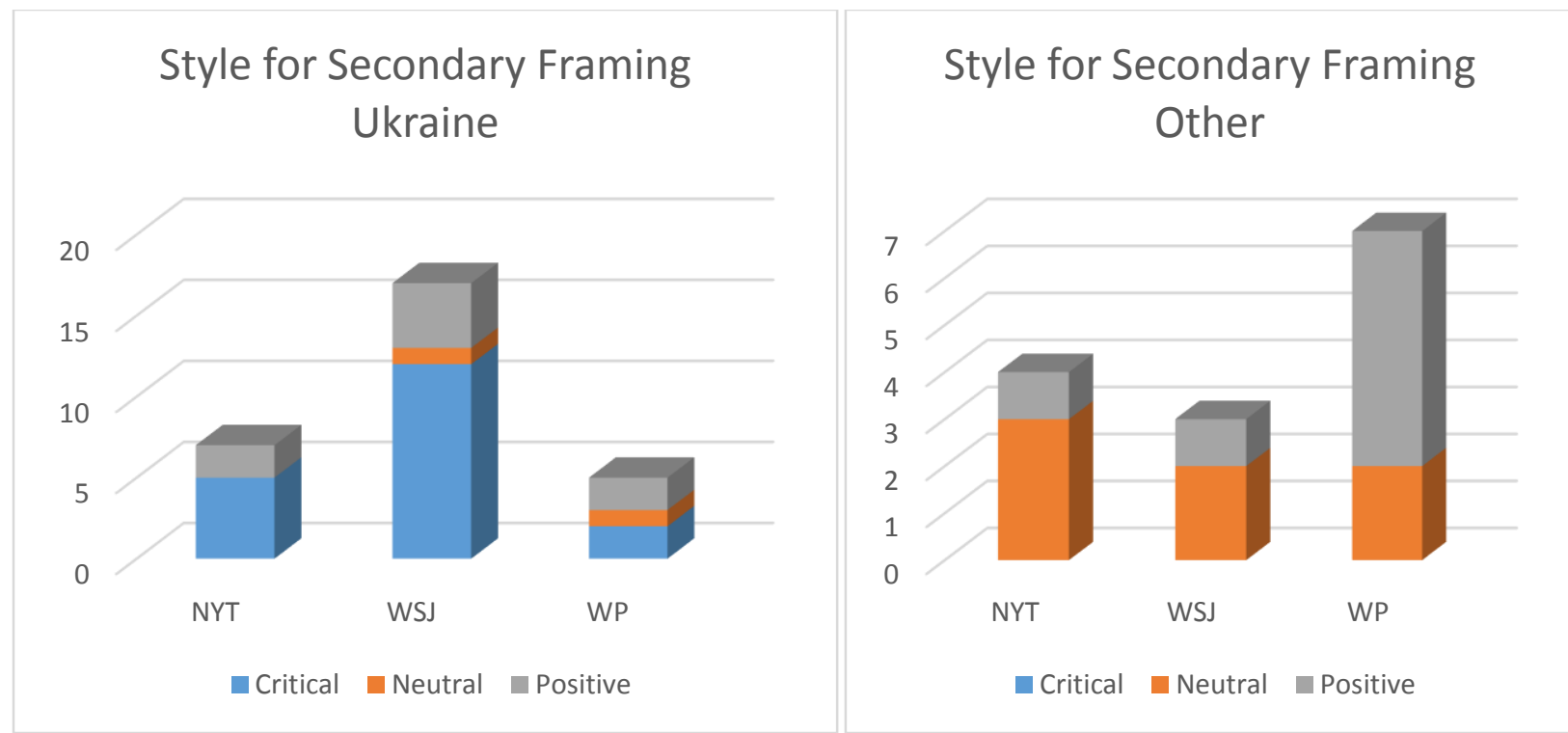

As we can see from these graphs, the secondary framing of an article is typically a place to express criticism. This is indicative of a tactic that I have dubbed "address and redirect." In this tactic, the article expresses briefly in its opening lines a variety of issues or criticisms about something that is only slightly related to the main topic of the article. For example, an article might begin by stating a few facts about the 2011-12 opposition protests in Russia and their suppression and dispersion. The article would briefly make mention that this is a troubling thing for Russia. However, it would then switch topics and state something innocuous or positive that would then become the main focal point of the rest of the article.

This simple misdirection is one of the primary ways that RBTH attempts to remain credible with its audience. They understand that most Americans will have heard something about the problems that face Russia. They also understand a principle of soft power that Nye explained simply as this, "preaching at foreigners is not the best way to convert them."171 This statement is at the heart of RBTH's strategy. When one reads enough of these articles (as I

\footnotetext{
${ }^{171}$ Nye, "Public Diplomacy and Soft Power," 103.
} 
have) he begins to get the sense that behind the scenes someone is utterly frustrated that the readers do not understand the situation as they do, and that they would love simply to just explain it bluntly to them. However, they diligently wait and continue to play a long game by using strategies such as "address and redirect" and others dicussed below.

The final point that should be made about these charts is that the large number of WSJ pieces about the Ukrainian Crisis are typically the result of another strategy; the situation in Ukraine is presented as bad for business. This is the foremost strategy employed in WSJ for discussions about Ukraine and the sanctions. There will be more about this a little later.

\section{Tertiary Framing}

The data set for the tertiary framing $(23)$ is very smaller than for the secondary framing. As a result, I will only provide a pie chart of the different categories:

\section{Tertiary Framing by Category}

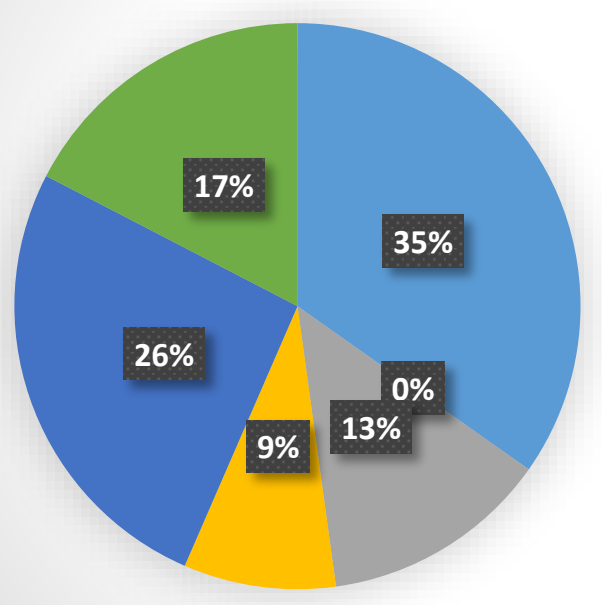

Politics

- Culture

History

Economics

- Ukrainian Crisis/Sanction

- Other

Again, the tertiary framing is typically a place that a small topic would be discussed and it would result in the use of "address and redirect." Because of the nature and length of a newspaper 
article, these mentions were usually appearing only in the largest of articles and warranted only a few sentences within them.

\section{Authorship and Geographic Location}

The main thing to take into account regarding authors beyond the fact that the vast majority of pieces are written by staff at RBTH or freelancers working directly for RBTH, is that with respect to the United States, RBTH is careful with its criticism, which makes perfect sense since it is trying to communicate to an American audience. When they do criticize the US directly without any qualifiers (i.e. both the West and Russia are to blame, etc.), the author tends to be American, or at least an American is central to the criticism. There were only five articles that were primarily targeted at the United States. Out of those five, American academics/thinktankers constituted three of the authors. The other two were a scathing interview with Oliver Stone, where he condemns the US and praises Russia, and an article written by an RBTH journalist that was critical of the outgoing ambassador to Russia, who he claims made very few friends during his time in Russia.

On the other side, there are eight articles primarily critical of only Russia, and 20 that are primarily critical of the Russian economy. However, this is not to say that there is no criticism of the United States. The difference is that this is contained in a collective criticism. There are 32 articles that are primarily critical of the United States and others, including Russia. In this case, there is a rather equal distribution of authors between a journalists from RBTH and an academic/thinktankers from the US or Russia. In the end, it is smart not to criticize the 
target country unless you have cover by way of an author from that country or that the target country is merely a part of a larger problem.

\subsection{Strategies}

As discussed briefly above, RBTH uses a variety of strategies to accomplish its mission of persuasion. Some are positive and some are negative. I will give a brief description of the main strategies and their usage. (NB: an article can use more than one strategy and as a result these categories can share articles. In addition, not all articles were coded with a strategy, for a variety of reasons such as they were too short, lacked substance, etc.)

\section{"Improving Relations with China"}

This strategy involves the basic idea of showing that sanctions and worsening ties will only lead Russia to grow closer to China, which it is perfectly happy to do. There were 18 total articles that employed this strategy and 16 of them were in WSJ, 2 in NYT and none in WP. In addition, this strategy increased over time. (NB: WSJ and NYT did not publish an October edition).

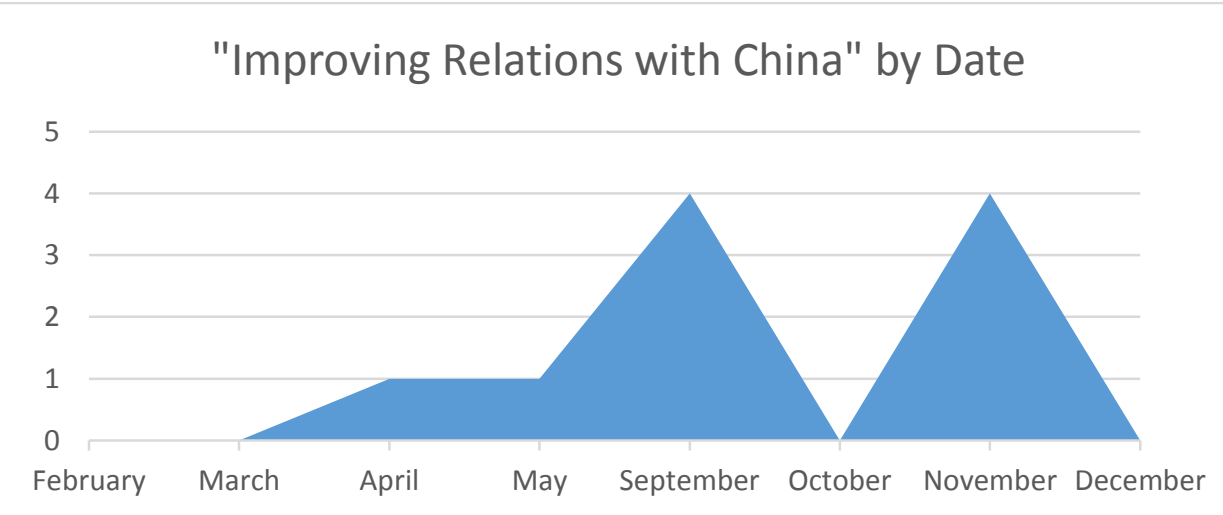

\section{"Internal Russian Politics"}


This category includes any discussions about internal Russian politics. Topics include articles about how the Russian Opposition was disorganized, how the Russian public supports the Russian government on Ukraine, and other articles about how Russians are united. There were only seven articles that employed this strategy ( 3 in WSJ and NYT each and 1 in WP).

\section{"Business not Politics"}

This is a straightforward category that simply tries to make the point that business is business and politics is politics. This strategy was employed 9 times ( 8 in WSJ and 1 in NYT). This strategy was also the general focus of the November WSJ supplement which featured 6 uses of this strategy.

\section{"Promoting cooperation"}

This category argues for greater levels of cooperation and includes tactics like "cooperation is key to success"; "we must end divisions"; "cross-cultural cooperation and education is highly needed!"; and "war is not the answer" (peace through cooperation). This strategy was employed 7 times (5 in WP and 2 in NYT). All of these happened in September (1), October (2), and November (4). This was one of the central themes for the November WP supplement.

\section{"Russia is not so different from the West"}

This category attempts to target common ground between Russia and the United States. This can be focused on pointing to positive similarities in terms of politics, culture, etc. Or it can be a little more negative in nature, such as "everyone hates terrorists/Islamic extremists so let's 
fight them together!" This code was used 36 times and the following graph will help to show how it was used.

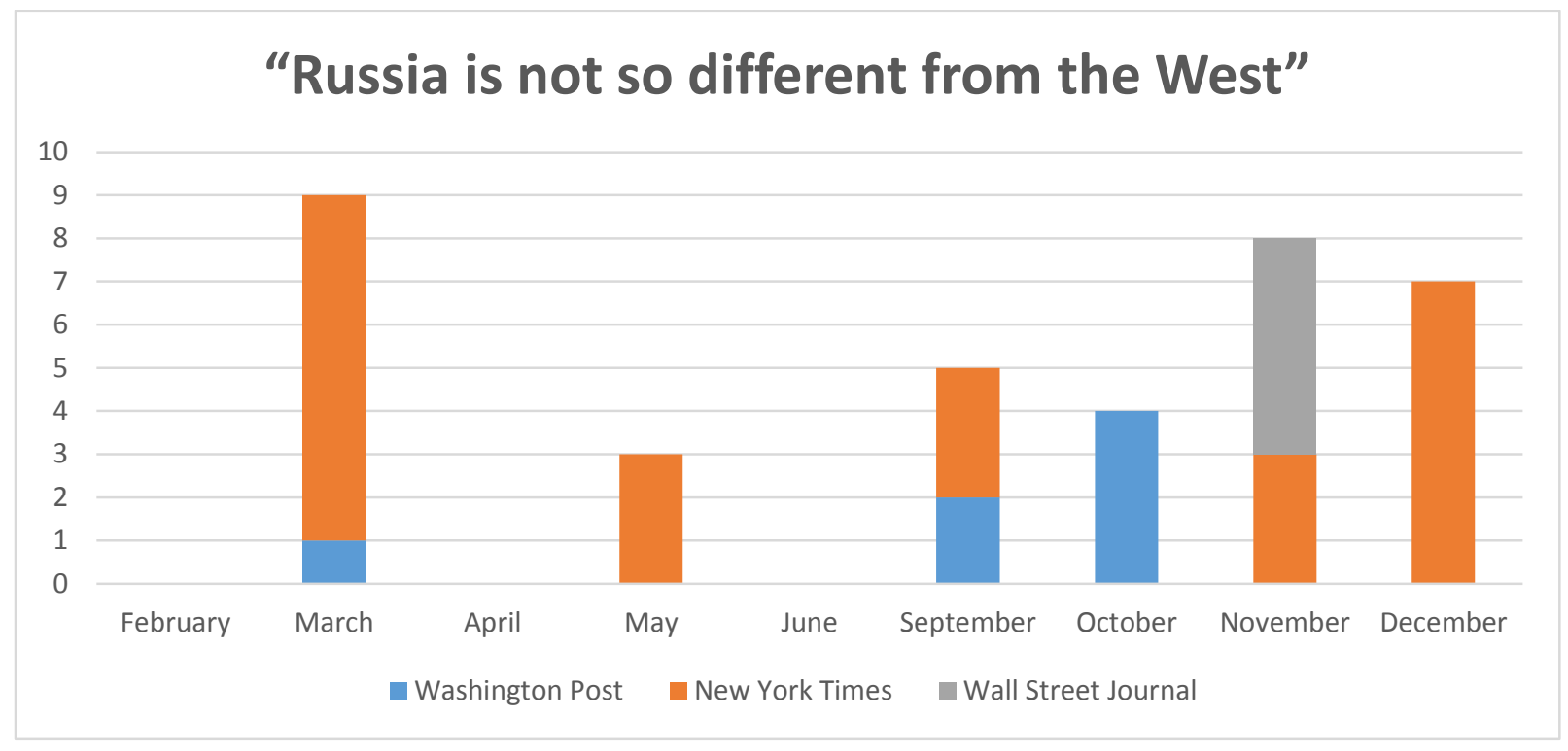

\section{"Americans and Russians are different"}

Vexingly this category takes the opposite tactic as the previous one. This category focuses on things like religious differences, that America and Russia are opposites in terms of culture, religion, and/or politics; and differences of opinion: "we see things differently from you". This category seems to be devoted to explaining why we don't understand each other, while the previous one could go hand in hand with the strategy of promoting cooperation. This strategy was used considerably less than the cooperation and similarities strategies discussed above. It was only used 4 times. Once in the April WP, and then once in the May, October, and November supplements of NYT.

\section{"Highlighting American and Russian ties/history/comradely/relations"}


This category is one of the central categories for RBTH. It focuses on promoting all of the successful experiences between Russia and the United States. This includes things like successful US-Russia Cooperation, explaining how Russians love American things (i.e. culture, food, etc.), and highlighting Russian culture in America. This strategy was used the most out of any strategy (91 times).

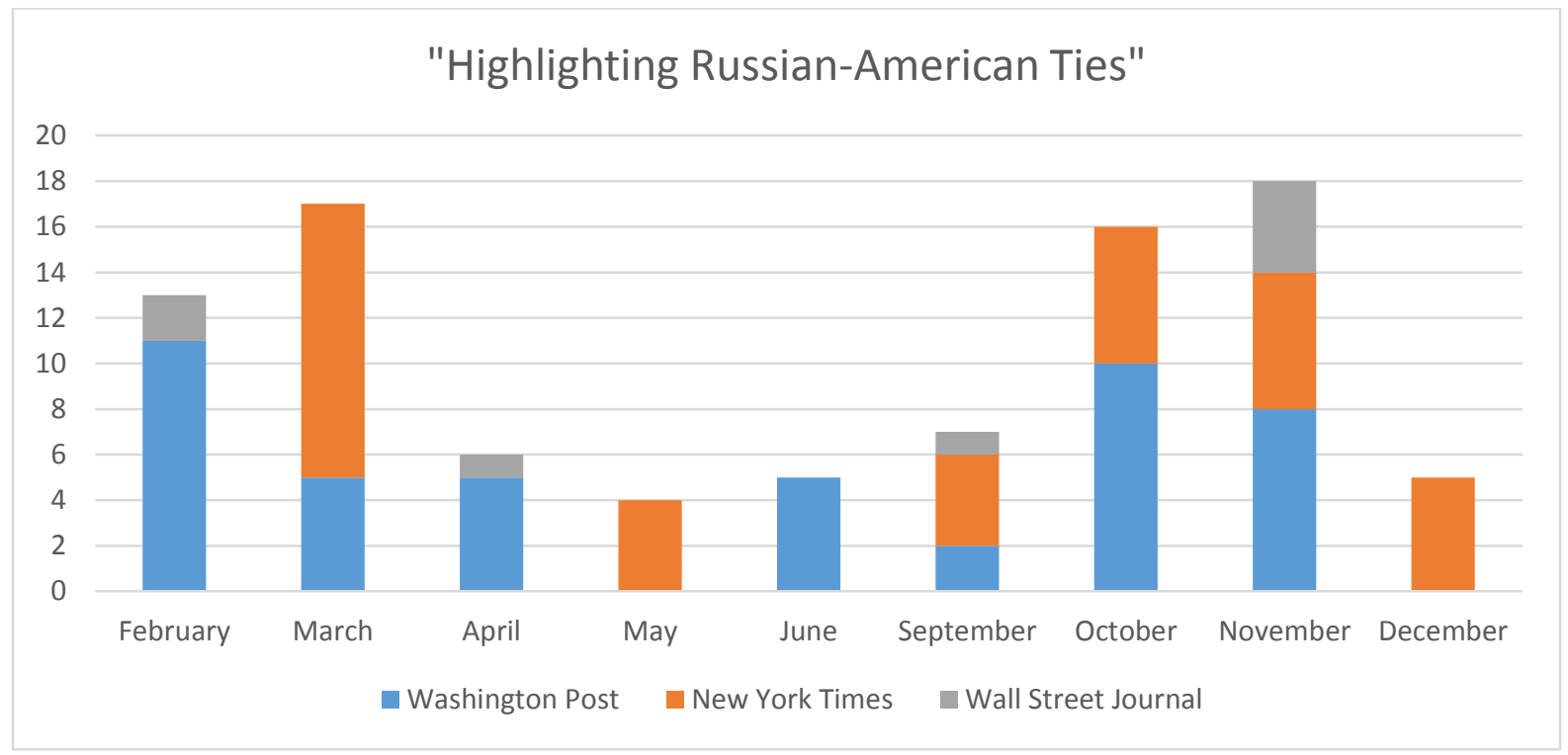

\section{"The Russian government is a force for good in the world and within Russia"}

This category is another rather large category and is designed as part of the heart of selling Russia to America. This category talks about things like the environment being equally important to Russia; how gender equality and human rights are also important to Russians; how Russia makes scientific advances; how Russia battles global problems like Ebola. In addition, the positive nature of internal Russian progress is discussed by arguing that "we are making great strides in" (for example) Russian Civil Society, which is healthy; coming to terms with the past; and the tolerance of other cultures. This category was used 24 times primarily in NYT (13) 
and WP (10). This also became a consistent focal point beginning in May and continuing through to November.

\section{"Russia is Modern/Modernizing/Globalized/Economically Friendly"}

This category is also a large part of attracting Americans to Russia, and in particular, businessinclined Americans. This category includes things like: approving of/highlighting clever Russian business tactics; arguing that independent competitors exist in Russia; Russia is more than just a producer of energy; Russia is globalized; Russia is making international business easier; Russia is combating corruption; Russia is an economic force to be reckoned with; Russians have influence and purchasing power in the US economy; Russia can and does compete with the West; Russia can take the economic fight to America; human rights progress is good for business; in Russia renewable energy is also important. Although this was not a focal point in WP (only 2 uses), NYT featured it 10 times and WSJ featured it 23 times. It was featured consistently throughout the year.

\section{"Russia is still cooperating with the world despite sanctions/tensions"}

In a similar manner to some of the earlier strategies, this strategy attempts to drive home the point that Russia is still focused on business regardless of the political atmosphere. This category also argues the point that there's still money to be made despite sanctions and the ongoing crisis in Ukraine. This was primarily used by the WSJ (11) times with only 2 uses each for WP and NYT. It was one of the focal points for the June and September WSJ editions, featuring 4 articles employing this strategy each month. 


\section{"We have a lot to offer"}

This category is another central strategy to cultivate favorable opinion toward Russia. This category includes the various attempts by RBTH to promote Russia's culture, science, technology, sports, etc. which RBTH believes will bring Russia into a more positive light. In addition, this category also includes items that are meant to improve Americans' knowledge of Russian culture etc. by teaching the readers about the Russian language and history as well as providing a children's section "RBTH for Kids" in NYT which teaches children about the language, culture, and important people from Russian history. This strategy has been employed more than all the strategies, on 73 occasions. The NYT supplement employs this strategy as a focal point for its entire edition with 43 uses of this strategy. WP also employs this strategy heavily with 25 uses. WSJ only used it 5 times. This makes sense due to the cultural focus of both the NYT and WP supplements.

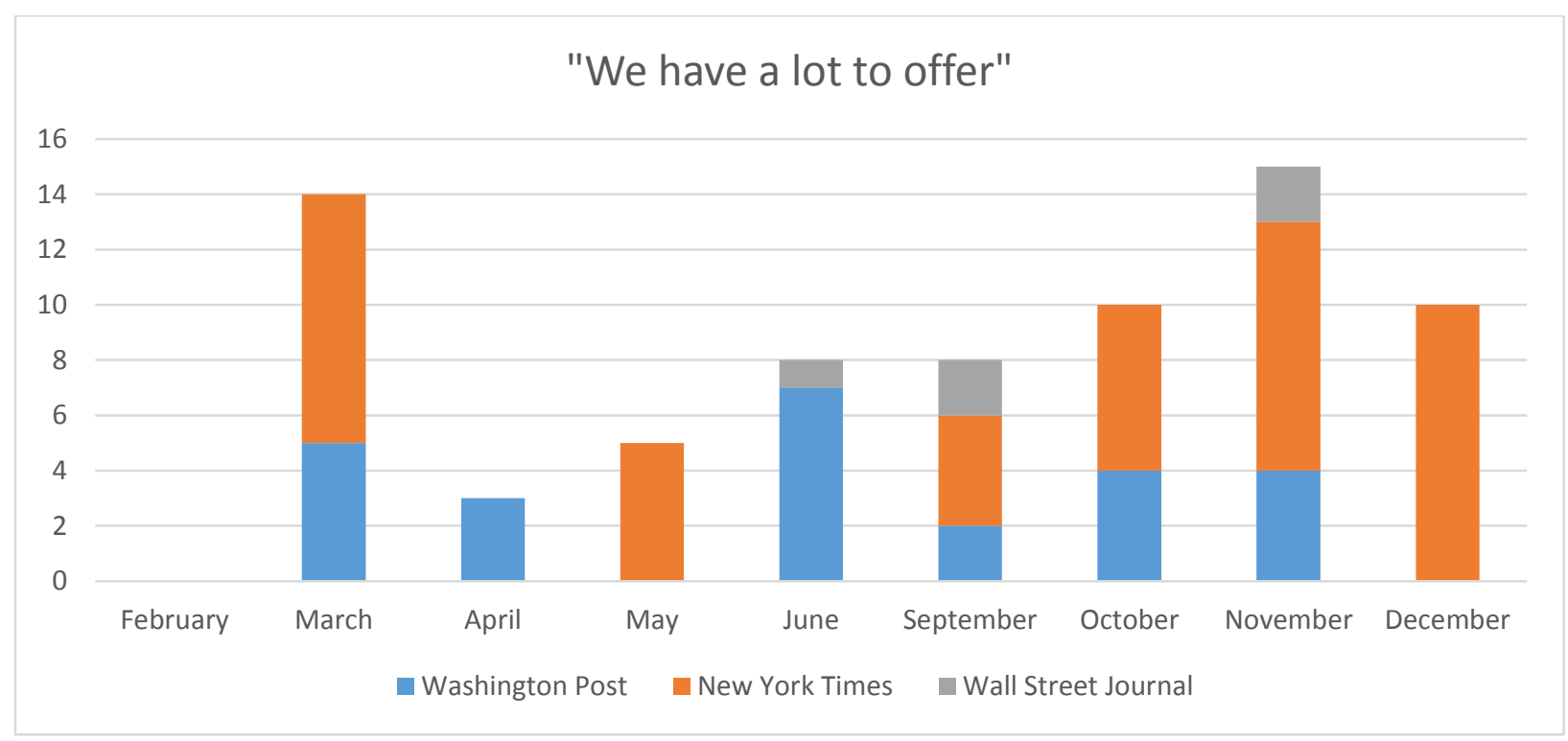




\section{"Historical challenge/explanation"}

This category also tends to try to teach the reader more about Russia. However, this strategy tends to be a bit more pontifical, but is fairly appealing to anyone with a history background as it attempts and typically succeeds at providing a nuanced view of history from both sides of an issue. It typically tends to favor the Russian interpretation of history, but this makes sense because it can be assumed that the reader more than likely already understands the American/Western version. A main issue in these articles is explaining how the Ukrainian Crisis was a long time coming. This strategy was used most heavily in the WP with 9 uses, including 3 in April that attempted to explain the Ukrainian crisis and the annexation of Crimea. The NYT supplement also used this 4 times, but never as concentrated. Interestingly, but not surprising, the WSJ supplement of RBTH never used this strategy.

\section{"Ukraine Needs Us"}

In this category, the authors attempt to highlight the closeness that they claim exist between Russia and Ukraine. This category is the main way of justifying the Ukrainian crisis and the annexation of Crimea, apart from the previous strategy. This category includes the subcategories that can be summed up in the following phrases: "Ukraine wants special treatment from us still"; "there is a humanitarian crisis Eastern Ukraine"; "Russia wants to work with Ukraine"; "Russia is able to help in Crimea or other areas that desperately need its help by providing finances and stability." Because of the dual political and economic nature of this category the RBTH supplements in WP and WSJ both employed it 4 times while it was only employed once in the NYT. 


\section{"Ukraine is Geopolitical"}

This strategy argues that the crisis in Ukraine is strictly a geopolitical crisis. Sub-strategies include: "the US doesn't actually care about Ukraine. It is actually interested in financial gain" and "America is interested in Ukraine for energy supremacy in Europe." This strategy was a relatively late edition with one article in NYT in October, then one article each in WSJ and NYT in November, and a final article in December in NYT.

\section{"Accusatory/ Negative/Critical towards the West/NATO/EU/America"}

This strategy calls out the West's alleged responsibility for various problems. Sub-strategies include: "the West does not understand what is going on"; "the West is not so great"; "NATO started it"; "Edward Snowden"; the US could bully businesses in America"; "the West doesn't want to get along with us"; "US overreach"; "the West is escalating tensions"; "the US and EU are running counter to the market"; "the EU backs out of economic negotiations"; and "Russia is cracking down on foreign meddling." Despite the wide range of possible uses of this strategy, it was only used 16 times (8 in WSJ, 5 in WP, 3 in NYT). Again this is not a terrible surprise, as criticism of the intended audience is less than productive in this environment.

\section{"Media Criticism"}

This strategy is critical of US/Western media bias. In addition, it is critical of black and white reporting. Despite the aforementioned studies confirming the existence of media bias toward Russia in the US, this was only pointed out 4 times ( 3 in WP and 1 in NYT).

\section{"The US and EU aren't playing by the Rules"}


This strategy attempts to claim that Russia is trying to play by the rules established by the US and EU, but that the US and EU won't abide by them. This category also claims that the sanctions against Russia are illegal. This strategy was employed primarily in supplements to WSJ (9 times) with 3 in the WP and 1 in NYT versions of RBTH.

\section{"Americans don't know much about Russia"}

This strategy is primarily focused on combatting stereotypes and other misconceptions that people in the United States have about Russia. This strategy was used 6 times with 3 in WP, 2 in NYT, and once in WSJ.

\section{"Sanctions could/do have an effect on America/Americans"}

This strategy is focused on how the sanctions could be bad for America (or the West). In addition this category likes to reassert the point that Russia has also imposed sanctions on the US/EU. Moreover, this category attempts to argue that sanctions hurt cooperation/progress, including in space. This strategy was primarily employed in the WSJ (10 times) and with increasing frequency later in the year. The NYT supplement used it 5 times while that for WP only used it twice.

\section{"Why do you want to keep hurting us?"}

This strategy is focused on the deterioration of the Russian economy during the latter part of 2014. A key component of this is the fact that many Russians believe that the sanctions are meant to hurt Russia(ns). This strategy was only used 3 times and only in the NYT. However, it was concentrated in November and December, and thus could possibly continue into 2015. 


\section{"Russia can survive sanctions/outlast the West"}

This strategy argues that Russia is resilient and essentially that Russians can cope with hardships, but can the West also cope with hardships? This strategy was used 14 times with half of the uses being in WSJ. The June supplement of WSJ had this strategy as a focal point. This strategy was also used in NYT as a focal point for the September edition, which constituted 3 of its 4 uses in that month.

\section{"Ukrainian crisis/sanctions are bad for business"}

This strategy is central to RBTH's response to the sanctions. It highlights a variety of different ways that Russia and the West could be making money, building relationships, etc. if it wasn't for these pesky sanctions. For the WSJ (24), and to a lesser extent NYT (8), this was a focal point for most of the year. As the chart below shows, both used this as a central focal point for one or more issues. In the case of WSJ, this strategy was the central focal point in 3 of the last 4 issues of the supplement for 2014. (NB: This strategy was never used in WP which is therefore omitted from the following graph.

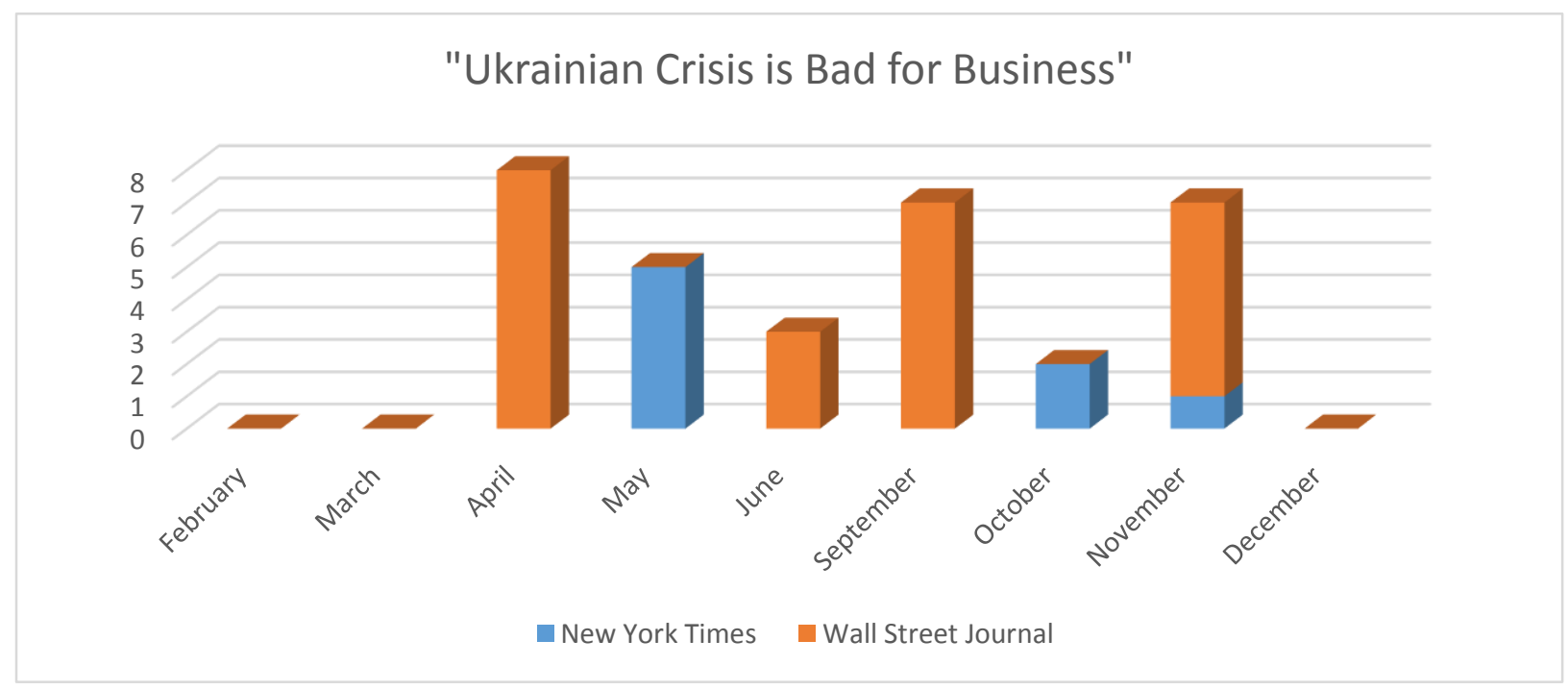




\section{Conclusions}

RBTH engages with the American people on a variety of different topics, using a variety of different tactics and strategies to attempt to "attract" the American people toward having a more favorable opinion of the government of the Russian Federation, the people of Russia, the businesses of Russia and the culture of Russia. Through my research, I have found that in general RBTH uses a systematic approach to the production of its supplements. Each supplement is structured and designed with the reader in mind, and it consistently provides the reader with coherent articles on topics of potential interest. RBTH employs a variety of strategies that aim to provoke and entice the reader into understanding more about the Russian mindset.

In addition, RBTH is specifically designed to engage with an elite demographic. This strategy is at the core of the RBTH mission, and its own website even makes mention of it. In this capacity, RBTH is a rather unique part of the Russian soft power/public diplomacy arsenal. Many of the other aspects of Russia's soft power/public diplomacy that are focused on media are often meant to flood the media with a multitude of stories that attempt to alter public perception by sheer force of size and abundance (e.g. RT, Rossiya Segodnaya). However, RBTH provides a very different weapon to Russia's soft power/public diplomacy arsenal due to its intended audience and the effectiveness with which its articles are able to mimic the journalist integrity of the parent newspapers that are connected to its publication. As such, I argue that continued study of RBTH is vital to understanding this new, more nuanced feature of Russian soft power/public diplomacy. 
The use of negative strategies runs somewhat counter to prevailing theories of production of effective soft power/public diplomacy cultivation techniques, but in the case of RBTH, they appear to be justified for two main reasons. First, the chaotic and volatile nature of the time when the supplements were published deemed it somewhat necessary to expose harsh truths and provide frank words on touchy subjects. Second, these negative strategies add a sense of legitimacy to the supplements for the reader. Quite frankly, anything written about Russian-US relations in the context of 2014 without at least some degree of confrontation would have seemed totally out of touch with reality. Tensions were high and relations were getting worse. To ignore this and pretend that all was well would have been disingenuous, and it certainly would have cost the supplements a significant amount of their credibility.

Beyond the negative aspects of part of the strategy, the pointed nature of each edition of the supplements to its specific audience is shown clearly in the strategies employed. In an overall sense, each edition tended to have a theme, which it wished to portray. Each theme would change over time as situations in the real world changed. For example, the early editions of 2014 (especially for the WSJ) were relatively subdued about the sanctions. They typically took the attitude that sanctions are an inconvenience, but Russians and Americans will work around them because, after all, business must go on. However, as the Russian economy began to seriously struggle in the second half of 2014, RBTH's attitude toward the sanctions changed dramatically. By the last quarter of the year, the supplements had taken on almost a pleading tone. However, at the same time they each remained resiliently optimistic (if not subtly so) about the future prospects of cooperation despite the sanctions. 
Ultimately, the RBTH supplements are an effective and useful tool in the cultivation and creation of soft power in the United States. As discussed above, these supplements reach large numbers of intelligent and influential Americans, with about half of these people reading at least some of the articles. Those who do engage with RBTH will find a series of thoughtful, wellwritten articles. Although these articles are produced with the expressed intention of influencing and attracting the reader to something that is probably foreign to them, they do not reflect any sinister intentions or other ominous dangers on the surface. Instead, these supplements focus primarily on creating a stronger human bond between the peoples and businesses of two of the most powerful states on earth, which have been locked in a fiercely competitive struggle for supremacy against one another for much of the last century. Regardless of the currently perceived dominance of the United States of America and the currently perceived isolation and weakness of the Russian Federation, the study of the machinations of the Russian Federation in terms of gaining larger popular support for its interests around the world (especially within the United States) is of vital importance. If the Russian Federation wishes to successfully influence policies of current foreign adversaries, then the aims and methods of RBTH and similar strategies will be the most important parts of this success, based largely on the elite demographic that they wish to engage through these efforts. As a result, further studies of RBTH are needed in order to fully understand what message the Russian Federation is trying to convey to this audience and whether it is successful in the delivery of this message. 


\section{Bibliography}

Anderson, Benedict R. O'G. Imagined Communities: Reflections on the Origin and Spread of Nationalism. London; New York: Verso, 1991.

Benjamin Bidder. "Putin Fights War of Images and Propaganda with Russia Today Channel." Spiegel Online, August 13, 2013. http://www.spiegel.de/international/business/putin-fights-war-ofimages-and-propaganda-with-russia-today-channel-a-916162.html.

Council on Foreign and Defense Policy (Совет по внешней и оборонной политике). "О Совете | Совет По Внешней И Оборонной Политике." Accessed February 20, 2015. http://svop.ru/about/.

Crowley, Michael. "Tit-for-Tat: Putin's Maddening Propaganda Trick." Time, May 1, 2014. http://time.com/84843/vladimir-putin-russia-propaganda/.

David-Fox, Michael. "From Illusory 'Society' to Intellectual 'Public': VOKS, International Travel and Party: Intelligentsia Relations in the Interwar Period." Contemporary European History 11, no. 1 (February 1, 2002): 7-32.

David-Fox, Michael. "The Fellow Travelers Revisited: The 'Cultured West' through Soviet Eyes." The Journal of Modern History 75, no. 2 (June 1, 2003): 300-335.

Delaney, Robert F, and John S Gibson. American Public Diplomacy: The Perspective of Fifty Years. Medford, Mass.: Tufts University, 1967.

Department Of State. The Office of Website Management, Bureau of Public Affairs. "Under Secretary for Public Diplomacy and Public Affairs," January 20, 2009. http://www.state.gov/r/.

Dolinsky, Alexey. "RIAC :: 'What Is Public Diplomacy, and Why Russia Needs It?.'” Accessed February 17, 2015. http://russiancouncil.ru/en/inner/?id_4=913\&from=nov\#top.

Ennis, Steven. "Propaganda Fears as Putin Replaces News Agency." BBC News. Accessed February 21, 2015. http://www.bbc.com/news/world-europe-25309139.

Fan, Ying. "Soft Power: Power of Attraction or Confusion?" Place Branding and Public Diplomacy 4, no. 2 (May 2008): 147-58. doi:10.1057/pb.2008.4.

Films for the Humanities \& Sciences (Firm), Films Media Group, and TED Conferences LLC. TEDTalks Joseph Nye - Global Power Shifts. Electronic resource (video). Films Media Group, 2012.

Greenslade, Roy. "Telegraph to Continue Publishing Russian Propaganda Supplement." The Guardian. Accessed February 18, 2015. http://www.theguardian.com/media/greenslade/2014/jul/29/dailytelegraph-russia.

Heritage, Timothy. "Putin Dissolves State News Agency, Tightens Grip on Russia Media." Reuters. December 9, 2013. http://www.reuters.com/article/2013/12/09/us-russia-mediaidUSBRE9B80I120131209.

Heyman, Stephen. "A Voice of Mother Russia, in English." The New York Times, May 18, 2008, sec. Arts / Television. http://www.nytimes.com/2008/05/18/arts/television/18heym.html.

loffe, Julia. "What Is Russia Today?" Columbia Journalism Review. Accessed February 18, 2015. http://www.cjr.org/feature/what_is_russia_today.php.

Katchanovski, Ivan, and Alicen Morley. "The Politics of U.S. Television Coverage of Post-Communist Countries." Problems of Post-Communism 59, no. 1 (January 2012): 15-30. doi:10.2753/PPC1075-8216590102.

Kim Zigfeld. "Articles: Misreporting on Russia." Accessed February 18, 2015. http://www.americanthinker.com/2012/12/misreporting_on_russia.html.

Krippendorff, Klaus. "Content Analysis." International Encyclopedia of Communication, January 1, 1989, 403-7.

Lieven, Anatol. “Against Russophobia." World Policy Journal 17, no. 4 (December 1, 2000): 25-32. 
LoGiurato, Brett. "RT Is Very Upset With John Kerry For Blasting Them As Putin's 'Propaganda Bullhorn.'” Business Insider. Accessed February 18, 2015. http://www.businessinsider.com/john-kerry-rtpropaganda-bullhorn-russia-today-2014-4.

Lygo, Emily. "Promoting Soviet Culture in Britain: The History of the Society for Cultural Relations between the Peoples of the British Commonwealth and the USSR, 1924-1945." The Modern Language Review 108, no. 2 (April 1, 2013): 571-96. doi:10.5699/modelangrevi.108.2.0571.

Maczka, Marcin. "The Propaganda Machine." Bi-Monthly Academic Magazine. New Eastern Europe, July 9, 2012. http://www.neweasterneurope.eu/interviews/320-the-propaganda-machine.

Merriam Webster. "Definition of Objective." Accessed February 19, 2015. http://www.merriamwebster.com/dictionary/objective.

- - - "Definition of Propaganda." Accessed February 19, 2015. http://www.merriamwebster.com/dictionary/propaganda.

Michael Moynihan. "Russia's International News Channel RT Warps the Truth About the Syrian Uprising." Tablet Magazine. Accessed February 18, 2015. http://tabletmag.com/jewish-newsand-politics/90971/disinformation.

Ministry of Foreign Affairs of the Russian Federation. "MFA of Russia | 02/18/2013 | Concept of the Foreign Policy of the Russian Federation." Accessed February 18, 2015. http://www.mid.ru/brp_4.nsf/0/76389FEC168189ED44257B2E0039B16D.

- - . "Россотрудничество | Rossotrudnichestvo." Accessed February 20, 2015. http://rs.gov.ru/.

Mor, Ben D. "Credibility Talk in Public Diplomacy." Review of International Studies 38, no. 2 (April 2012): 393-422. doi:http://dx.doi.org.www.libproxy.wvu.edu/10.1017/S0260210511000489.

Moscow State Institute of International Relations. "About MGIMO." Accessed February 20, 2015. http://english.mgimo.ru/about-mgimo.

Myers, Steven Lee. "Without Notice, Putin Dissolves a News Agency." The New York Times, December 9, 2013, sec. World / Europe. http://www.nytimes.com/2013/12/10/world/europe/putin-scrapskremlin-news-agencies.html.

National Research University Higher School of Economics. "History - National Research University Higher School of Economics." Accessed February 20, 2015. http://www.hse.ru/en/info/hist/.

Nicholas, Larraine. "Fellow Travellers: Dance and British Cold War Politics in the Early 1950s." Dance Research: The Journal of the Society for Dance Research 19, no. 2 (December 1, 2001): 83-105. doi:10.2307/1290977.

Norris, Pippa. "The Restless Searchlight: Network News Framing of the Post-Cold War World." Political Communication 12 (December 1995): 357-70.

Nye, Joseph S. Soft Power: The Means to Success in World Politics. New York: Public Affairs, 2004.

- - - "What China and Russia Don't Get About Soft Power." Foreign Policy. Accessed February 16, 2015. http://foreignpolicy.com/2013/04/29/what-china-and-russia-dont-get-about-soft-power/.

Nye, Joseph S., Jr. "Public Diplomacy and Soft Power." Annals of the American Academy of Political and Social Science 616 (March 1, 2008): 94-109.

Pells, Richard H. Not like Us: How Europeans Have Loved, Hated, and Transformed American Culture since World War II. New York, NY: Basic Books, 1997.

Peter Pomerantsev. "How Russia Is Revolutionizing Information Warfare." Defense One. Accessed February 18, 2015. http://www.defenseone.com/threats/2014/09/how-russia-revolutionizinginformation-warfare/93635/.

Pew Research Center. "Global Indicators Database." Pew Research Center's Global Attitudes Project. Accessed February 18, 2015. http://www.pewglobal.org/database/.

Prokhorov, A. M. Great Soviet encyclopedia. New York: Macmillan, 1973.

Putin, Vladimir. "Meeting with Russian Ambassadors and Permanent Representatives in International Organisations." President of Russia, July 9, 2012. http://eng.kremlin.ru/transcripts/4145. 
RFE/RL. "Putin Reorganizes State Media Into New Conglomerate." RadioFreeEurope/RadioLiberty, December 9, 2013, sec. Russia. http://www.rferl.org/content/russia-new-newsagency/25194336.html.

RIA Novosti. "About Us - The Russian News \& Information Agency RIA Novosti." Accessed June 11, 2013. http://www.rianovosti.com/docs/about/novosti.html.

RT. "About Us - RT." Accessed February 21, 2015. http://rt.com/about-us/.

Russia Beyond The Headlines. "Company | Russia Beyond The Headlines." Accessed January 28, 2015. http://rbth.co.uk/about_us/company.

Russian International Affairs Council. "RIAC :: General Information." Accessed February 20, 2015. http://russiancouncil.ru/en/about-us/what_is_riac/.

Russian Presidential Executive Office. "President of Russia." Accessed February 21, 2015. http://eng.kremlin.ru/acts/6387.

Russkiy Mir Foundation. "Russkiy Mir Foundation." Accessed February 20, 2015. http://russkiymir.ru/en/.

Sandford, Daniel. "Russian News Agency Closed down." BBC News. Accessed February 21, 2015. http://www.bbc.com/news/world-europe-25299116.

Scheufele, Bertram. "Content Analysis, Quantitative." The International Encyclopedia of Communication. Blackwell Reference Online. Blackwell Publishing, n.d. <http://www.communicationencyclopedia.com/subscriber/tocnode.html?id=g9781405131995_ yr2013_chunk_g97814051319958_ss136-1>.

---. "Grounded Theory." The International Encyclopedia of Communication. Blackwell Reference Online. Blackwell Publishing, n.d.

http://www.communicationencyclopedia.com/subscriber/tocnode.html?id=g9781405131995_y r2013_chunk_g97814051319958_ss136-1.

Shafer, Jack. "Hail to the Return of Motherland-Protecting Propaganda!" Slate, August 30, 2007. http://www.slate.com/articles/news_and_politics/press_box/2007/08/hail_to_the_return_of_ motherlandprotecting_propaganda.html.

Sputnik International. “About Us - Sputnik International.” Accessed February 21, 2015. http://sputniknews.com/docs/about/index.html.

- - . "RIA Novosti to Be Liquidated in State-Owned Media Overhaul / Sputnik International." Accessed February 21, 2015. http://sputniknews.com/russia/20131209/185390572/Russia-AnnouncesState-Owned-Media-Overhaul.html.

Statista. "New York Times: Circulation 2014 | Statistic." Statista. Accessed February 22, 2015. http://www.statista.com/statistics/193792/average-paid-circulation-of-the-new-york-times/.

- - - "Wall Street Journal: Circulation 2014 | Statistic." Statista. Accessed February 22, 2015. http://www.statista.com/statistics/193788/average-paid-circulation-of-the-wall-street-journal/.

- - . "Washington Post: Circulation 2014 | Statistic." Statista. Accessed February 22, 2015. http://www.statista.com/statistics/193818/average-paid-circulation-of-the-washington-post/.

The Alexander Gorchakov Public Diplomacy Fund. "Mission and Goals - The Alexander Gorchakov Public Diplomacy Fund." Accessed February 21, 2015. http://gorchakovfund.ru/en/about/mission/.

The Voice of Russia. "About Us : The Voice of Russia: News, Breaking News, Politics, Economics, Business, Russia, International Current Events, Expert Opinion, Podcasts, Video." Accessed February 21, 2015. http://sputniknews.com/voiceofrussia/about/.

Tsygankov, Andrei P. "Blaming Moscow: The Power of the Anti-Russia Lobby." Global Dialogue 11 (Winter 2009): 64-73.

Tsygankov, Andrei P. Russophobia: Anti-Russian Lobby and American Foreign Policy. New York: Palgrave Macmillan, 2009. 
Valdai International Discussion Club. "Valdai - About." Accessed February 20, 2015. http://valdaiclub.com/about/. 


\section{Appendix}

1. List of RBTH Supplements Analyzed

\begin{tabular}{|l|l|}
\hline Publisher & Date \\
\hline Wall Street Journal & February 1, 2014 \\
\hline Washington Post & February 5, 2014 \\
\hline Washington Post & March 5, 2014 \\
\hline New York Times & March 28, 2014 \\
\hline Washington Post & April 2, 2014 \\
\hline Wall Street Journal & April 5, 2014 \\
\hline New York Times & May 21, 2014 \\
\hline Washington Post & June 4, 2014 \\
\hline Wall Street Journal & June 7, 2014 \\
\hline Washington Post & September 3, 2014 \\
\hline New York Times & September 17, 2014 \\
\hline Wall Street Journal & September 26, 2014 \\
\hline Washington Post & October 1, 2014 \\
\hline New York Times & October 15, 2014 \\
\hline Washington Post & November 5, 2014 \\
\hline New York Times & November 19, 2014 \\
\hline Wall Street Journal & November 29, 2014 \\
\hline New York Times & December 17, 2014 \\
\hline
\end{tabular}

